GEOLOGICAL SURVEY CIRCULAR 733

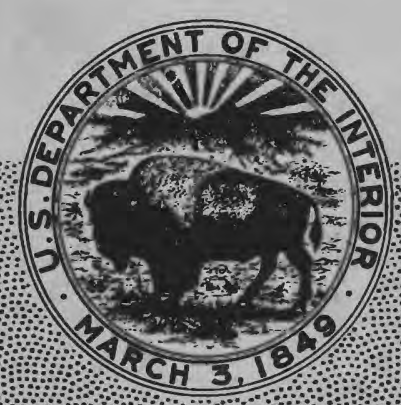

The United States Geological Survey in Alaska: Accomplishments During 1975 
The United States Geological Survey in Alaska: Accomplishments During 1975

Edward H. Cobb, Editor

GEOLOGICAL SURVEY CIRCULAR 733 


\section{United States Department of the Interior}

THOMAS S. KLEPPE, Secretary

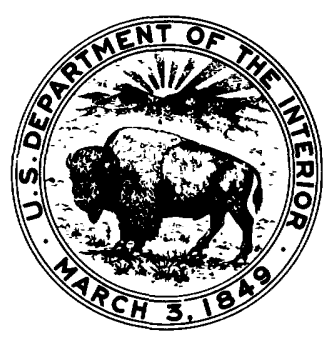

\section{Geological Survey}

V. E. McKelvey, Director

Library of Congress Cataloging in Publication Data

Cobb, Edward $\mathbf{H}$.

The United States Geological Survey in Alaska.

(Geological Survey Circular 733)

Supt. of Docs. no.: I 19.4/2:733

1. United States Geological Survey 2. Geological research-Alaska. 3. Geology-Alaska-

Bibliography. I. Cobb, Edward Huntington, 1916- II. United States Geological Survey

III. Series: United States Geological Survey Circular 733.

QE75.C5 no. 733[QE74] 557.3'08s[557.98]

$76-608093$ 


\section{CONTENTS}

Abstract

Summary of important results, 1975

Introduction _._.

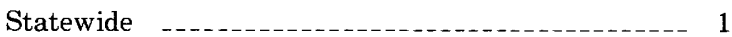

Computer files of Alaskan data, by M. Elizabeth Yount

Mineral resources of Alaska, by Edward $\mathrm{H}$. Cobb

New gravity map of Alaska, by David F.

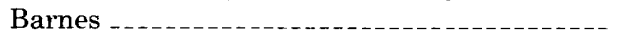

Exploration geochemistry in Alaska, by G. C. Curtin, G. W. Day, C. L. Forn, T. D. Hessin, J. C. Hoffman, S. P. Marsh, R. M. O'Leary, and R. B. Tripp.

Alaskan quality-of-water network (NASQAN), by R. J. Madison

Streamflow, channel erosion, and icings along TAPS route, by J. M. Childers _._._._._. 8

Water quality and benthic invertebrates along the TAPS route, by J. W. Nauman and D. R. Kernodle

Investigations of impact on hydrologic features by construction and operation of TAPS, by C. E. Sloan

Arctic water resources and environmental studies, by J. M. Childers

Hydrologic reconnaissance of TAPS haulroad, by S. H. Jones

Surficial geologic mapping in the Philip Smith Mountains and Chandalar quadrangles, Brooks Range, by Thomas D. Hamilton and Robert M. Thorsen

Displacement of Yukon-derived sediment from northern Bering Sea to southern Chukchi Sea during the Holocene, by C. Hans Nelson and Joe S. Creager

"New" volcanoes in the Aleutian volcanic arc, by Thomas P. Miller and Robert L. Smith _-_._- 11

Reconnaissance geochemistry and tectonics of Gulf of Alaska greenstones, by Gary R. Winkler

Uplift rates of marine terrace sequences in the Gulf of Alaska, by Travis Hudson, George Plafker, and Meyer Rubin

Structural style of part of the Outer Continental Shelf in the Gulf of Alaska Tertiary Province, by Terry R. Bruns and George Plafker _._._. 13

The Border Ranges fault system in the Saint Elias Mountains and Alexander Archipelago, by George Plafker, D. L. Jones, Travis Hudson, and H. C. Berg
Summary of important results, 1975-Continued

Page

Northern Alaska -

Seabed morphology adjacent to an "island" of grounded ice in the Arctic Ocean northwest of Point Barrow, by L. J. Toimil and Arthur Grantz _.................... 16

Possible solid gas hydrate and natural gas deposits beneath the continental slope of the Beaufort Sea, by Arthur Grantz, Gary Boucher. and Olive Therese Whitney _..._._- 17

Sediment-ice interaction in the Beaufort Sea, by Peter W. Barnes and Erk Reimnitz _._._._._- 17

Study of the gravity field of the Beaufort shelf, north coast of Alaska, by Gary Boucher._._. 21

Environmental data collection along proposed Canadian gas pipeline along coastal route in Alaska, by J. P. Meckel _. 23

Arctic hydrology studies, by C. E. Sloan _-...- 23

North Slope water resources studies, by Gordon L. Nelson _._._._._._._._._._._._. 23

North Slope petroleum program, by Robert D. Carter -............. 23

New structural and stratigraphic interpretations, central and western Brooks Range and Arctic Slope, by C. G. Mull, I. L. Tailleur, C. F. Mayfield, and G. H. Pessel _._._._. 24

Petroleum potential of the Lisburne Group, by

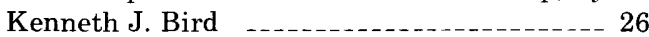

Need to revise and test estimates of northern Alaska coal resources, by I. L. Tailleur and W. P. Brosgé $-26$

Informal cooperation between U.S. Geological Survey and State of Alaska, Division of Geological and Geophysical Surveys in the Brooks Range, by I. L. Tailleur, G. H. Pessel, W. P. Brosgé, and C. F. Mayfield

Northern Alaska coal investigations, western Naval Petroleum Reserve No. 4, by James E. Callahan _...... 30

Hydrological studies for the Alaskan Air Command, by R. J. Madison

Interpretation of depositional environments in the Fortress Mountain Formation, central Arctic Slope, by R. E. Hunter and J. E. Fox --- 30

Metamorphism in the southwestern Brooks Range, by C. F. Mayfield _._. 31

Biostratigraphy of the Permian and Lower Triassic rocks in the Philip Smith Mountains quadrangle, by Robert L. Detterman _..._._._. 32

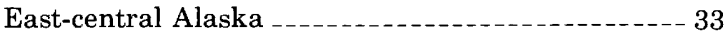

Geochemical reconnaissance of the Chandalar quadrangle, by Sherman P. Marsh 
Summary of important results,1975-Continued

East-central Alaska-Continued

Geohydrology of the Fairbanks North Star Borough, by Gordon L. Nelson _............. 34

Reconnaissance geologic mapping in the eastern Big Delta quadrangle, by Helen L. Foster and Florence R. Weber

West-central Alaska

Trace-element composition of biotite from a tingranite complex, Seward Peninsula, by Travis Hudson and R. E. Mays

Revised interpretation of regional geological controls of mineralization in southwest Seward Peninsula, by C. L. Hummel 37

Uranium and thorium content of radioactive phases of the Zane Hills pluton, by Mortimer $\mathrm{H}$. Staatz and Thomas P. Miller

Progress report on new geologic mapping in the Ruby quadrangle, by Robert M. Chapman _- 41

Newly discovered Upper Triassic and Lower Cretaceous strata in the northern Kuskokwim Mountains, by William W. Patton, Jr. 42

Sedimentary facies and structure of the northern Bering epicontinental shelf, by C. Hans Nelson, Robert W. Roland, and Sam W. Stoker 43 Southwestern Alaska

Water-resources reconnaissance of St. George Island, Pribilof Islands, by G. S. Anderson _... 43

Mercury dispersal in Kuskokwim River and Bay, by C. Hans Nelson, Everett A. Jenne, and Dennis H. Sorg 43

Atomodesma in southwestern Alaska, by Joseph M. Hoare and Warren L. Coonrad _-_._-_._ 44

The Togiak tuya, by Warren L. Coonrad and Joseph M. Hoare 44

Two caldera-forming eruptions on Umnak Island, eastern Aleutian Islands, by Thomas P. Miller and Robert L. Smith

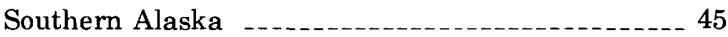

Hydrologic investigations related to coal resources, by D. R. Scully _._. 45

Alaska glaciology studies, by D. C. Trabant _._. 45 Glaciers along TAPS route, by D. C. Trabant _- 47 Water-resources investigations of the ValdezDelta Junction area, by C. E. Sloan $-47$

Reconnaissance geology of the western Talkeetna Mountain quadrangle, by W. H. Nelson, Béla Csejtey, Jr., and R. M. Dean

Geochemical anomalies in the Willow Creek mining district, Talkeetna Mountains, by M. L. Silberman and R. M. O'Leary

LANDSAT data interpretation of the Nabesna and McCarthy quadrangles, by Nairn R. D. Albert

Relations between Triassic carbonate sabkhas and Kennecott-type copper deposits, Wrangell Mountains, by A. K. Armstrong and E. M. MacKevett, Jr. 50

Stable isotope, sulfide mineralogy, fluid inclusion, and $\mathrm{K}$-Ar age study of the massive sulfide deposits at Kennecott, by M. L. Silberman, R. W. Potter II, and Arie Nissenbaum
Summary of important results, 1975 - Continued

Southern Alaska-Continued

Ash flows associated with Wrangell Volcano, by

Thomas P. Miller and Robert L. Smith _._._- 52

Engineering geology of the Greater Anchorage Area Borough, by Ernest Dobrovolny and Henry R. Schmoll _._._-_._-_._._._. 52

Geohydrology of the Anchorage area, by Chester Zenone -...... 52

Estimate of time required for natural restoration of the effects of the 1964 earthquake at Portage, by A. T. Ovenshine and Reuben Kachadoorian _.......................... 53

Lake-level fluctuations, North Kenai area, by G.

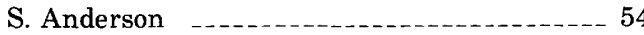

Summary of the geology and coal resources of the Bering River Coal Field, by R. B. Sanders _- 54

Reconnaissance engineering geology and geologic hazards of the Yakutat area, by L. A. Yehle _. 54

Gulf of Alaska seismicity, by John C. Lahr and Michael Blackford

Submarine mass movement of Holocene sediments seaward of the Copper River, by Paul R. Carlson and Bruce F. Molnia _._._._._. 55

Surface sedimentary units of the northern Gulf of Alaska continental shelf, by Bruce F. Molnia and Paul R. Carlson

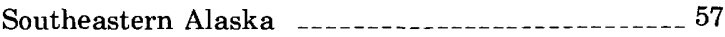

Late Holocene offset features along the Fairweather fault, by George Plafker, Travis Hudson, and Meyer Rubin _._._._._._._._._._. 57

Miocene mollusks from the Topsy Formation, Lituya district, by Louie Marincovich........ 58

Glacier Bay National Monument mineralresource studies recommenced, by David A. Brew, Donald Grybeck, B. R. Johnson, and Constance J. Nutt

Apparent pre-middle Tertiary right-lateral offset on Excursion Inlet fault, Glacier Bay National Monument, by David A. Brew, Christine Carlson, and Constance J. Nutt

Key foliated quartz diorite sill along southwest side of Coast Range complex, northern southeastern Alaska, by David A. Brew, A. B. Ford, Donald Grybeck, Bruce R. Johnson, and Constance J. Nutt

Aquifer investigations in Mendenhall Valley near Juneau, by Gary O. Balding _-..-_-_ 60

Automated observatory system installed at Sitka Observatory, by Willis T. Osbakken _......- 60

Limnological investigations in southeastern Alaska, by G. A. McCoy _._. 61

Progress report on geologic investigations in the Craig quadrangle, by G. Donald Eberlein and Michael Churkin, Jr.

Progress report on geology and mineral resources of the Ketchikan quadrangle, by H. C. Berg, R. L. Elliott, and R. D. Koch 62

Reports on Alaska published by members of the U.S. Geological Survey in late 1974 and 1975 , compiled by M. E. Tailleur 


\section{ILLUSTRATIONS}

Figure 1. Regions of Alaska used in this report Page

2. Location map, studies discussed in summary of important results

3. Location map, studies discussed in summary of important results

4. Sketch map showing preliminary interpretations from new gravity map of Alaska

5. Photograph of Trans-Alaska Pipeline System crossing of the Tonsina River, March 27, 1975

6. Chart of preliminary results of radiocarbon dating of marine terrace sequences between Cape Yakataga and Icy Bay, in the vicinity of Lituya Bay, and on Middleton Island

7. Index map showing the location of the Border Ranges Fault and its major segments in the Saint Elias Mountains and Alexander Archipelago, other major faults, and important fossil localities _...... 15

8. Aerial photograph of "Katies's Floeberg" as viewed from the northeast from an altitude of about $500 \mathrm{~m}$

9. Schematic representation of ice-bottom interactions on the shelf north of Alaska

10. Conceptual model relating intensity of agent (ice and water) to water depth, and seasonal changes in ice-water regime - .

11. Profiles of free-air and Bouguer anomalies and regional correction, Beaufort shelf

12. Section and index map, central Brooks Range transect

13. Photograph of a Lower Cretaceous olistostrome in the western Brooks Range

14. Reconnaissance geologic map of the eastern Big Delta quadrangle

15. Map showing major structures and mineralized areas in southwest Seward Peninsula

16. Geologic sketch map of the Ruby quadrangle

17. Aerial photograph of Sanford Glacier with Mount Drum in the background, Wrangell Mountains, April, $1974 \quad 46$

18. Curve depicting the rate of build-up of the intertidal sediment surface at Portage

19. Orthographic drawing of large submarine slide on Holocene sediment into Kayak Trough

20. Index map, aeromagnetic coverage for the State of Alaska

\section{TABLES}

TABLE 1. Average range of trace-element abundances in biotites from some felsic intrusive rocks in the western United

States and from the Serpentine Hot Springs area
2. Uranium, thorium and potassium content of selected grab samples from the radioactive phases of the Zane Hills pluton 


\title{
The United States Geological Survey in Alaska: Accomplishments during 1975
}

\author{
Edward H. Cobb, Editor
}

\begin{abstract}
This report of accomplishments of the U.S. Geological Survey in Alaska during 1975 is organized in two chapters. The first consists of short summaries of the important results of research projects and the second lists those reports and maps covering various phases of the geology and mineral and water resources of the State that were prepared by Geological Survey personnel and published in late 1974 and 1975.
\end{abstract}

\section{SUMMARY OF IMPORTANT RESULTS}

\section{INTRODUCTION}

Significant new scientific and economic geologic information has resulted from many topical and field investigations of the Geological Survey in Alaska during the past year. Discussions of the findings, or, in some instances, narratives of the course of the investigations, are grouped under seven subdivisions corresponding to six major geographic regions (fig. 1) and a general, statewide category, which includes discussions that fall in more than one of the regional subdivisions. Locations of the study areas are shown on the accompanying index maps (figs. 2 and 3 ).

\section{STATEWIDE}

Computer files of Alaskan data

By M. Elizabeth Yount

The Branch of Alaskan Geology, as part of an effort to make the information in its technical data files more accessible, has built or cooperated in building several computer-based files containing Alaska data. The first file to be built was a joint effort of the Alaskan Branch and the Office of Resource Analysis. A manual card file of Alaskan mineral occurrences, created and maintained by Edward H. Cobb, was keypunched for entry into the Computerized Resources Information
Bank-CRIB (Calkins and others, 1973). Because the file was then in machine-readable form, the Office of Resource Analysis fed the data into a sophisticated, but simple-to-use, interactive computer storage and retrieval system for testing from remote locations. Observations of users' interaction with the data base were made using terminals located in U.S. Geological Survey offices in Fairbanks, Anchorage, Juneau, and Spokane. The file is maintained by the Office of Resource Analysis and updated by the Alaskan Branch. Updating is now progressing to incorporate annotations on the citations and a summary on each occurrence.

A second file was initially conceived as a companion file to contain the complete citations which appear in abbreviated form in the mineral occurrences file. It has since grown to include any U.S. Geological Survey, U.S. Bureau of Mines, or State of Alaska publication pertinent to the geology of Alaska. It includes these classes of publications through 1974, and is expected to contain the 1975 citations by late Spring 1976. The file is indexed primarily by $1: 250,000$ quadrangle. Plans are to augment the bibliography with citations to nongovernment literature on a gradual basis as the quadrangle indexing is volunteered by file users. To attempt to include all possible nongovernment literature is beyond the resources of this project.

The Alaskan Branch is helping to complete Alaskan coverage in a file of fossil reports maintained by the Branch of Paleontology and Stratigraphy in Washington, D.C. That branch routinely inputs new reports and as time allows is working back in historic reports. The Alaskan Branch started with its earliest reports, working forward in time. Old reports are typed in Menlo Park, mailed to Washington, D.C., and added to the data 
base via an optical scanner. Reports to 1911 have been included.

Visitors to the Alaskan Technical Data Unit, Menlo Park, are welcome to search the bibliography and mineral occurrence file from the terminal located there. To assure wider distribution of the material in these two files, plans are being made to publish both computer output microfiche and a computer tape copy of each of the files through the National Technical Information Service. For further information about the fossil reports file, contact the Branch of Paleontology and Stratigraphy, National Museum, Washington, D.C. 20244.

\section{REFERENCE CITED}

Calkins, J. A., Kays, Olaf, and Keefer, E. K., 1973, CRIB-The mineral resources data bank of the U.S. Geological Survey: U.S. Geol. Survey Circ. 681, 39 p.

\section{Mineral resources of Alaska}

By Edward H. Cobb

Products of this office project during 1975 comprised 10 published maps (scale 1:2,500,000), each showing the distribution in Alaska of occurrences of a metallic mineral commodity; an open-filed list of recent Federal and State reports on the geology and mineral resources of Alaska, indexed by topographic mapping quadrangle (scale 1:250,000); and open-filed summaries of references to individual mineral occurrences (other than mineral fuels and construction materials) in 18 quadrangles in west-central and northern Alaska. Previously compiled bibliographic and mineralresource reference material was made available to the Alaskan Branch information processing project for entry into computerized storage and retrieval banks.

\section{New gravity map of Alaska}

By David F. Barnes

A new Bouguer gravity map of Alaska at a scale of $1: 2,500,000$ ( 1 inch equals about 40 miles) prepared by D. F. Barnes will be released during the calendar year 1976. The map was compiled from about 30,000 Alaska land-gravity measurements plus approximately 40,000 kilometers of surfaceship gravimeter traverses over the bordering continental shelves. More than a third of the land stations were obtained between 1958 and 1974 during small-boat traverses along rivers and shorelines. The basic data consist of a skeletal

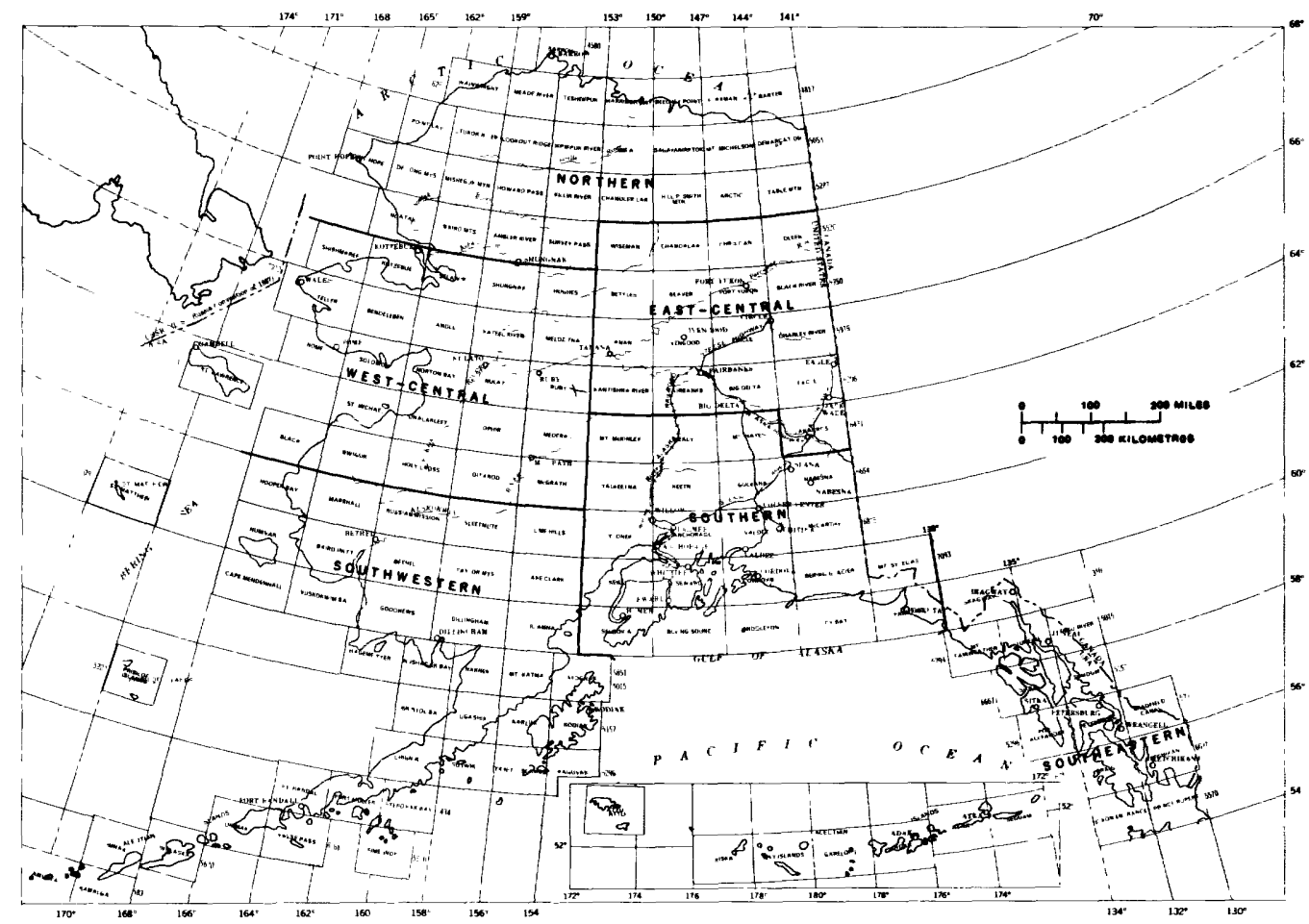

Figure 1.-Regions of Alaska used in this report. 


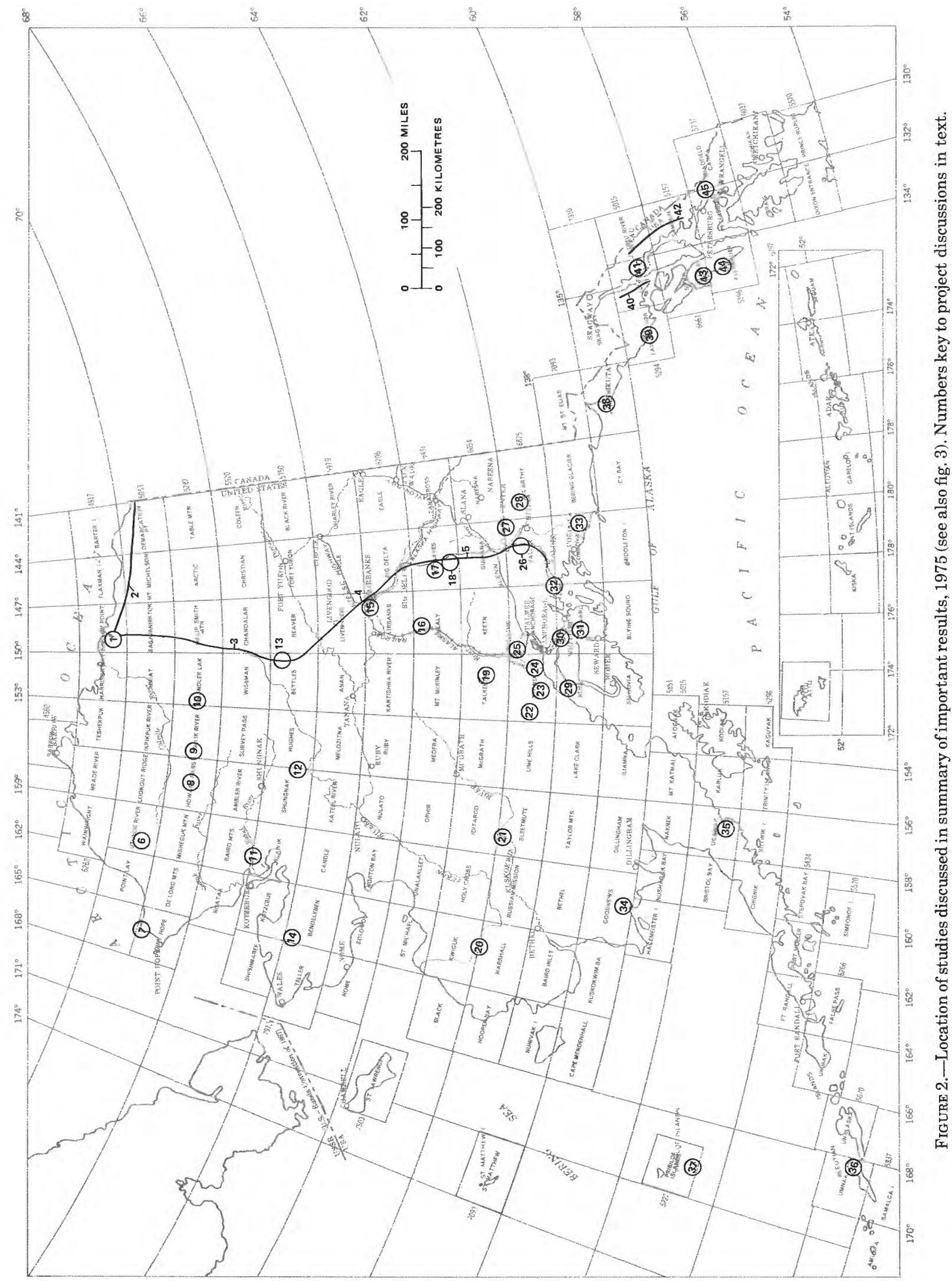


s

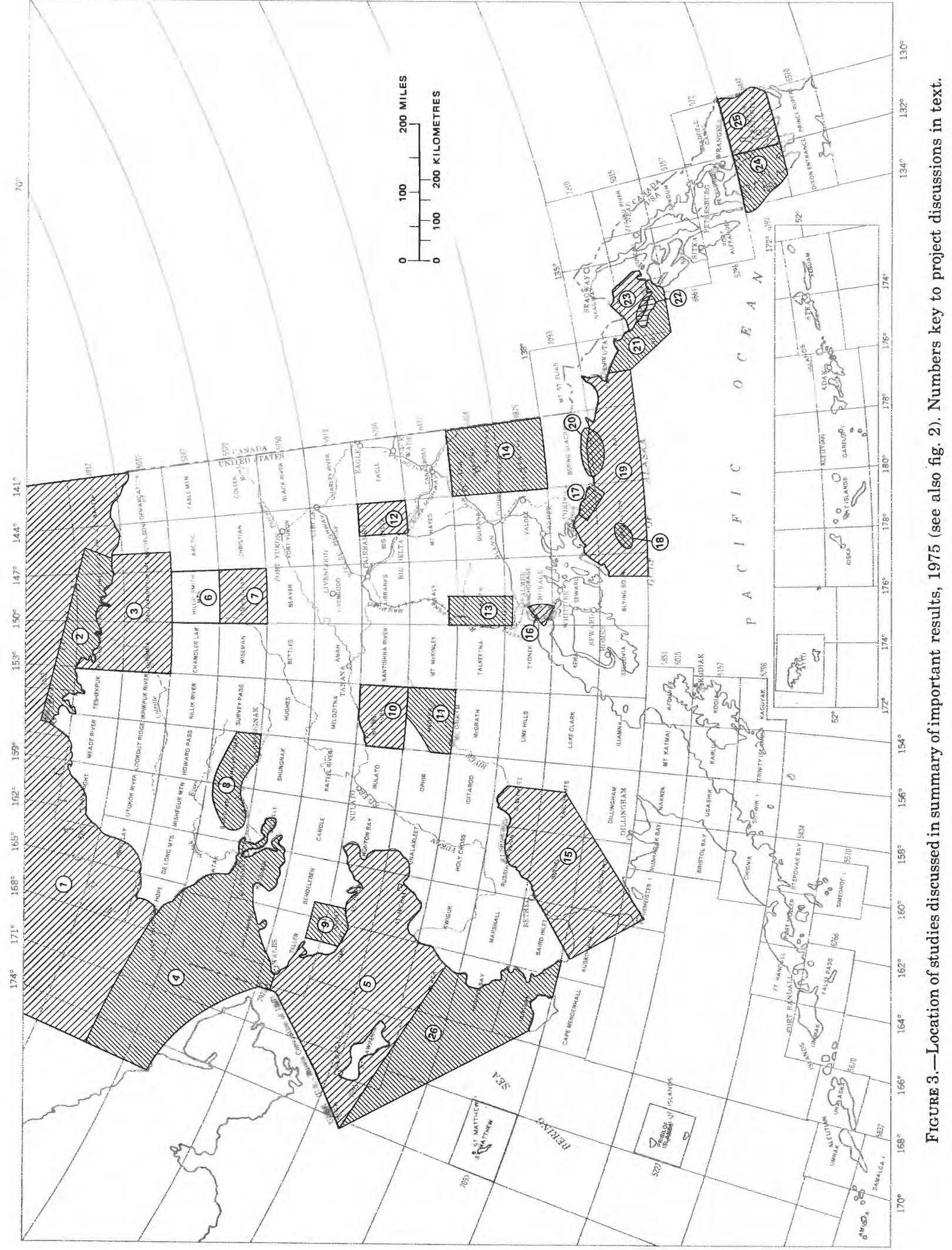


network of widely spaced traverses along which stations are separated by distances of 2 to $5 \mathrm{~km}$. Additional measurements by float-plane, skiplane, and helicopter landings and a few detailed surveys provide a more systematic coverage, best developed in the northern and eastern parts of the State. Much of the data reduction was performed by desk calculators, and most contouring was done by hand at a scale of 1:250,000 so that available geologic and aeromagnetic maps could be used as supplemental data. Gravity datum for the map was obtained from the 1971 International Gravity Standardization Net; the reductions employed the 1967 International Reference Ellipsoid and a density of $2,670 \mathrm{~kg} / \mathrm{m}^{3}$.

The map may eventually aid the solution of several types of problems in different physical sciences such as geodesy, geophysics and geology. It provides a method for calculating the gravitational acceleration in various parts of Alaska, for estimating the deflection of the vertical, and for removing regional gradients from local gravity surveys. Figure 4 shows some of the preliminary geologic interpretations which have been made from the map and which are discussed in greater detail in a brief text that will accompany the map.

The contours of estimated crustal thickness were generalized from the gravity contours by using the empirical relations between Bouguer gravity and crustal thickness derived from worldwide data by Woollard and Strange (1962) and converted to the new datum and ellipsoid for Alaskan latitudes. Both those workers and Barnes $(1969,1971)$ have shown that these empirical relations are not accurate in areas where tectonic processes predominate over processes of isostatic adjustment. Such tectonic activity controls gravity anomalies in island arcs and other areas of plate convergence such as the Gulf of Alaska coastal region. The northern boundary of the gravitational effects of this tectonic activity and the southern limit of possible usefulness of the empirical relation is somewhat arbitrarily placed as shown on the sketch map by the heavy dotted line. The contours do, however, suggest a crust that is thinner than that in most of western North America and show the probable increase in thickness beneath the interior mountain ranges.

Several small gravity lows have been interpreted as Cenozoic basins filled with low-density sediments and sedimentary rocks. In the illustration, these lows are shown as hachured closures, other lows better interpreted as low-density intrusions are left off. Most of the Cenozoic-basin gravity lows are close to large faults and are within topographic basins of much larger area. The structural basins, filled primarily by pre-Cenozoic rocks, are better adjusted isostatically and are less clearly defined as gravity lows. Delineation of such basins generally requires more detailed gravity data, and such sedimentary basins have been left off the preliminary interpretation map (fig. 4).

Much of the map compilation involved the recognition of several linear or arcuate gravity highs, shown as heavy dashed lines or dashes on the illustration. The highs are indicated either by adequate gravity data or by a few gravity measurements suggesting characteristic association of high gravity anomalies with either elongate rock outcrops or elongate aeromagnetic anomaly patterns. The limited evidence for some of the features and the variable causes of the highs are discussed in greater detail in a text that accompanies the gravity map. The features are shown on figure 4 because they may represent former plate or tectonic boundaries, because many of the highs seem to be associated with mineralization, and because they are such prominent features of the Alaskan gravity map.

\section{REFERENCES CITED}

Barnes, D. F., 1969, Lack of isostatic adjustment on two Alaskan continental margins: Geol. Soc. America Abs. with Programs, 1969, Ann. Mtgs., V. 1, no. 7, p. 254-256.

1971, Gravitational evidence concerning the thickness of the Alaskan crust: Internat. Symposium on Arctic Geology, 2d, Program Abs., Am. Assoc. Petroleum Geologists, p. 59 .

Woollard, G. P., and Strange, W. E., 1962, Gravity anomalies and the crust of the earth in the Pacific basin, in MacDonald, G. A., and Kuno, Hisaki, eds., The crust of the Pacific basin: Am. Geophys. Union Geophys. Mon. no. 6, p. $60-80$.

Exploration geochemistry in Alaska

By G. C. Curtin, G. W. Day, C. L. Forn, T. D. Hessin, J. D. Hoffman, S. P. Marsh, R. M. O'Leary, and R. B. Tripp

During the 1975 field season, the Branch of Exploration Research participated in the Alaskan Mineral Resource Appraisal Program (PAMRAP-AMRAP) and Wilderness Studies in various parts of Alaska. About 8,000 samples were collected by Branch geochemists during PAMRAP-AMRAP reconnaissance geochemical studies and by Branch of Alaskan Geology geologists in nine 1:250,000-scale quadrangles: 


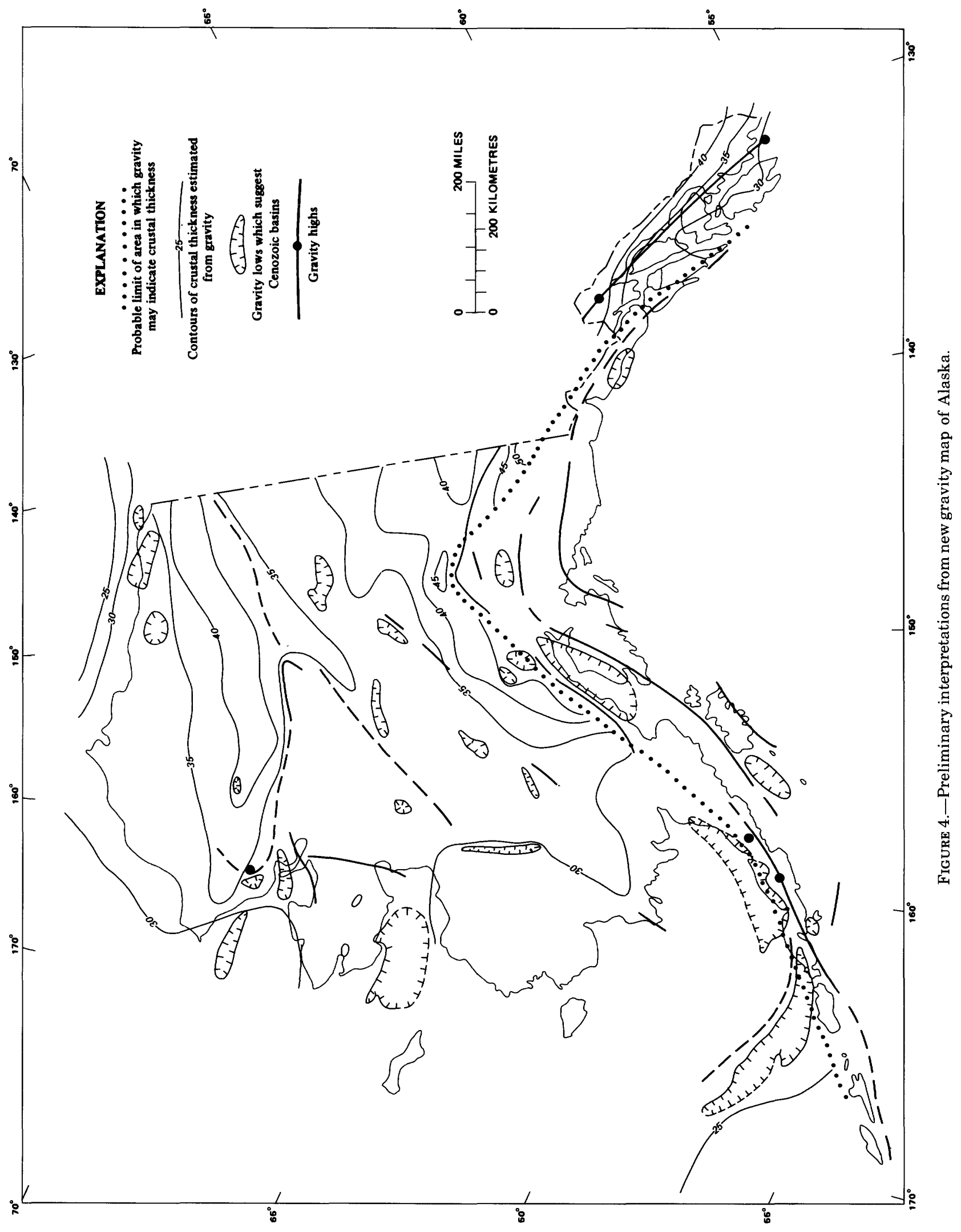


Big Delta, Blying Sound, Chandalar, Goodnews, Hagemeister Island, Ketchikan, Seward, Talkeetna, and Talkeetna Mountains. More than 4,000 of these samples were analyzed in the Anchorage Laboratory during the field season. In addition, about 1,500 samples were analyzed in mobile laboratories stationed at the Bureau of Mines facility in Juneau in support of Wilderness Studies in the Tracy Arm-Fords Terror and Glacier Bay National Monument Wilderness Study Areas.

Besides aiding in the mineral-resource assessment of the above-named quadrangles, preliminary results of the PAMRAP-AMRAP studies indicate that separate sampling programs are necessary to describe adequately the areas of mineral potential in at least two kinds of Alaskan terraines: rugged mountainous terrains such as the Brooks and Alaska Ranges and maturely dissected terrains such as the Yukon-Tanana Upland and the area of the Goodnews and Hagemeister Island quadrangles. The results indicate that more than one sample medium is required in reconnaissance geochemical surveys in these environments in order to define adequately areas of mineral potential.

Because the primary weathering process in the rugged mountainous terrains is mechanical rather than chemical, relatively fresh fragments from both country rock and mineralized zones are deposited in the streams to produce a mineralogy that reflects the mineralogy of the bedrock in the drainage basins. The collection of stream sediments and panned concentrates from streams draining areas of $5-15 \mathrm{~km}^{2}$ is therefore adequate, on a reconnaissance basis, to define areas of mineral potential. Analysis of bedrock collected at a somewhat lower sampling density aids in defining the chemical composition of the bedrock and in interpreting geochemical results of the streamsediment and panned-concentrate sampling.

Chemical weathering apparently plays an important role in the weathering processes in maturely dissected terrains. In this environment, elements probably migrate in solution from bedrock and colluvium and eventually infiltrate streams. The elements are then scavenged by materials such as secondary Fe-Mn oxides and related materials in stream sediment, streambank sod (mixed organic and inorganic material) beneath the water level, and aquatic bryophytes (mosses). Analyses of these media show that the hydromorphic anomalies produced by the scavenging processes define both known mineralized zones and potential areas of concealed mineralized rock. Analyses of clastic stream-sediment material, on the other hand, reveal only relatively weak, isolated anomalies that do not adequately define areas of mineral potential. The weak anomalies may be the result of dilution by barren material that constitutes the bulk of the stream sediment and by the selective destruction or alteration by weathering of sulfides and other ore minerals. The effects of weathering and dilution are reversed, however, through concentration of the heavymineral fraction of the stream sediment by panning. The high metal content, especially of Sn and $\mathrm{W}$, in heavy-mineral concentrates defines areas similar to those outlined by high metal content in the scavenging agents. The results indicate that panned concentrates and scavenging agents such as oxalic-acid-leachable Fe-Mn oxides and related materials of the stream sediment and the streambank sod are sample media useful for reconnaissance geochemical exploration in this environment.

\section{Alaskan quality-of-water station network (NASQAN)} By R. J. Madison

Six new monitoring stations were established under the Geological Survey's National Stream Quality Accounting Network (NASQAN) (Ficke and Hawkinson, 1975). The program was designed to measure a range of water quality characteristics and to provide information to those involved in planning or managing water resources. Objectives of the program are to account for amount and quality of water, to show variability, to detect streamwater quality changes, and provide data from which future assessments may be made. The NASQAN sites in Alaska are: Stikine River near Wrangell (fig. 2 (45)), Susitna River at Susitna Station (fig. 2 (24)), Kuskokwim River at Crooked Creek (fig. 2 (21)), Yukon River at Pilot Station (fig. 2 (20)), Kobuk River near Kiana (fig. 2 (11)), and Kuparuk River near Deadhorse (fig. 2 (1)).

\section{REFERENCE CITED}

Ficke, J. F., and Hawkinson, R. O., 1975, The National Stream Quality Accounting Network (NASQAN)-Some questions and answers: U.S. Geol. Survey Circ. 719, 23 p. 
Streamflow, channel erosion, and icings along TAPS route By J. M. Childers

Stream-discharge and water-quality records from 10 gaging stations established along TAPS route (fig. 2 (3-5)) during 1970-73 provided new hydrologic data, especially in the Arctic, and baseline data for evaluating environmental impacts. Channel erosion and the causative factors-floods, ice, and construction disturbancewere resurveyed and aerial photography retaken at 25 pipeline stream-crossing sites. Aerial photogrammetry was advantageously used at selected broad, braided channel sites.

An aerial reconnaissance of icings along the pipeline route was made in May 1975. Photographs of significant icings were made and the location and extent of icings plotted on 1:250,000 scale maps. Icings were a significant problem for road maintenance between Prospect Camp and Galbraith Lake Camp through the Brooks Range. The impacts of icings on erosion and flooding during breakup will increase as construction progresses.

Water quality and benthic invertebrates along the TAPS route By J. W. Nauman and D. R. Kernodle

Streams along the TAPS route (fig. $2(3-5)$ ) can be classified as glacial and nonglacial. These stream types reflect the cold Alaskan climate; summer water temperatures are low. High discharge rates occur during late spring and early summer; winter ice cover, lasting more than 6 months, results in prolonged low flow.

Nonglacial streams with high snowmelt contributions generally have peak flows during spring breakup. These streams tend to be clear and have low turbidity except during spring breakup and after summer rainstorms. In glacial streams, glacier melt water sustains summer runoff levels. The streams are milky and turbid from large amounts of suspended inorganic sediment. Water in both types of streams becomes clear during winter. Low flows at that time are due to reduced surface runoff.

Peak suspended-sediment loads range from 0 to $4,000 \mathrm{mg} / \mathrm{l}$ for nonglacial streams and 1 to 9,300 $\mathrm{mg} / 1$ in glacial streams. Similarly, turbidity is much greater in glacial streams than in nonglacial waters, ranging from 0 to $510 \mathrm{JTU}$ in glacial streams and from 0 to $270 \mathrm{JTU}$ in nonglacial streams. Total organic carbon values are slightly higher for nonglacial streams, ranging from 0.5 to
$60 \mathrm{mg} / \mathrm{l}$, and from 0.5 to $14 \mathrm{mg} / \mathrm{l}$ in glacial streams. Correspondingly, ammonia (as $\mathrm{N}$ ) ranges from 0.01 to $0.88 \mathrm{mg} / \mathrm{l}$ for nonglacial streams, 0.01 to $0.08 \mathrm{mg} / \mathrm{l}$ in glacial streams.

The higher turbidity and suspended-sediment loads in glacial streams as well as their lower total organic carbon and ammonia contents seem to explain the difference in abundance of benthic organisms noted in the two stream types. During the summer, benthic invertebrate average abundance is approximately 2,800 organisms per square metre for nonglacial streams and 550 organisms per square metre in glacial streams. The major benthic invertebrate groups are also represented by increased numbers of genera in nonglacial streams. Chironomidae (midges), Simuliidae (blackflies), and Ephemeroptera (mayflies) genera were approximately twice as abundant in nonglacial streams. There seems to be, however, little difference in the abundance of Plecoptera (stoneflies) in these two stream types.

In the three climatic zones (Arctic, Continental, and Maritime) crossed by the pipeline route, glacial stream benthic invertebrates were more abundant, on the average, in the Maritime zone, whereas nonglacial streams had greater numbers of organisms in the Continental climatic zone.

Investigations of impact on hydrologic features by construction and operation of TAPS

By C. E. Sloan

The Tonsina River (fig. 2 (26)) near Glennallen was the site of the first river crossing by the trans-Alaska pipeline (fig. 5) on March 27, 1975. The Tonsina River is a glacier-fed coarse-bed stream that flows through a large lake upstream from the site. Natural turbidity in the stream immediately upstream from the crossing zone was about $30 \mathrm{JTU}$ at a stream-flow rate of about $70 \mathrm{ft}^{3} / \mathrm{s}$ and a velocity of about $2 \mathrm{ft} / \mathrm{s}(0.61 \mathrm{~m} / \mathrm{s})$. Turbidity increased to about 400 JTU immediately downstream from the crossing during excavation of the pipeline trench. Turbidity as high as 135 JTU was observed 5 miles $(8 \mathrm{~km})$ downstream from the crossing. The river cleansed itself rapidly after ditching was completed and within 12 hours was approaching natural background levels. The turbidity resulting from construction disturbance had no measurable effect on specific conductance or concentration of dissolved oxygen in the river.

The Little Tonsina River (fig. 2 (26)) was crossed on April 12 and backfilling began on April 13. The 


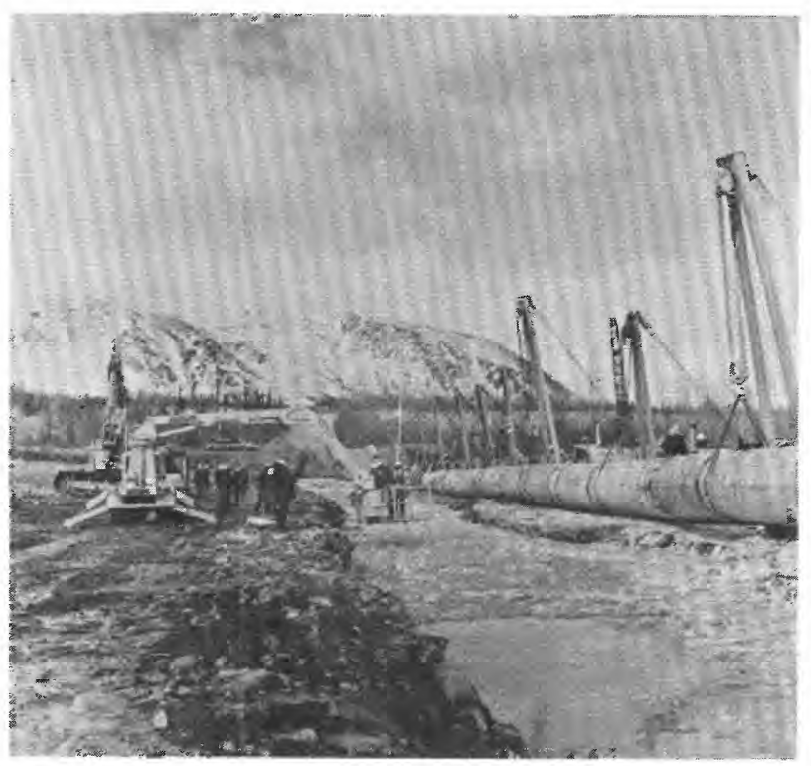

Figure 5.-Trans-Alaska Pipeline System crossing of the Tonsina River, March 27, 1975.

Little Tonsina is a clear-water, salmon-spawning stream tributary to the Tonsina River. Background turbidity above the crossing was 5 JTU; downstream maximum during backfilling was $1,500 \mathrm{JTU}$. Discharge was about $8 \mathrm{ft}^{3} / \mathrm{s}$ and most of the sediment introduced into the stream appeared to settle out within half a mile $(800 \mathrm{~m})$ of the crossing. Chironomid larvae, stonefly, and mayfly nymphs were found on stream-bottom substrates upstream from the crossing, but no benthic invertebrates were found a short distance downstream from the crossing, even though an equal sampling effort was expended. Benthic studies in late July 1975 in the Little Tonsina indicated that a healthy benthic community had repopulated the stream substrate in the affected reach.

A study of the hydrology of treated sewage effluent at selected pipeline camps found only one site where there was evidence of impact on a receiving water. The Jim River at Prospect Camp (fig. 2 (13)) receives dilute sewage effluent as ground-water seepage along the left bank; this results in low dissolved oxygen and relatively high total organic carbon, chloride and sulfate contents. However, this effect is quite localized and does little to impair the quality of water in the main channel downstream from the camp.
Arctic water resources and environmental studies By J. M. Childers

Channel surveys at 25 stream crossing sites along TAPS route (fig. 2 (3-5)) during 1975 have been compared with preconstruction surveys at the sites to measure erosion. Aerial photogrammetry was used advantageously at broad, braided stream crossing sites for the channel erosion survey. Boat surveys were made at selected sites during significant flooding to measure local scour. Flood scour measured at the Salcha River in 1975 resulted in design revision requiring deeper burial of the pipeline than originally planned. These channel erosion surveys are part of a continuing study of the interactions of floods, ice, and construction on stream channels along TAPS route.

Hydrologic reconnaissance during April and August 1975 provided data to help evaluate hazards from floods, ice, and channel erosion along the proposed Arctic Gas Pipeline (fig. 2 (2)) coastal route. Quality and availability of water at selected streams, lakes and springs were measured to help evaluate potential developmental impacts on water resources.

Hydrologic reconnaissance of selected large streams (including the Colville River) has provided information for planning stream-gaging and water-quality sampling stations. Data from these stations could be used in defining important streamflow characteristics of the central and eastern North Slope of Alaska.

\section{Hydrologic reconnaissance of TAPS haulroad} By S. H. Jones

A hydrologic reconnaissance of the TAPS haulroad (fig. 2 (3)) during breakup in May 1975 found no notable floods or erosion at bridges and culverts. Severe icings occurred at numerous culverts and bridges, causing local erosion and flooding, however. Significant erosion at the embankment slopes occurred between the South Fork, Koyukuk River, and Coldfoot Camp where frozen silts were exposed to thawing and runoff.

As snowmelt runoff was relatively low in 1975, another attempt to observe flooding will be made during spring breakup of 1976 if snow accumulation is high.

Surficial geologic mapping in the Philip Smith Mountains and Chandalar quadrangles, Brooks Range

By Thomas D. Hamilton and Robert M. Thorson

Reconnaissance mapping of surficial geologic 
deposits has been completed for about 70 percent of the Philip Smith Mountains quadrangle (fig. 3 (6)) and 50 percent of the Chandalar quadrangle (fig. 3 (7)). The most extensive units mapped in each quadrangle include glacial drift sheets and outwash trains, postglacial alluvial and lacustrine deposits, and solifluction sheets. Talus cones and aprons, alpine fans, landslide deposits, rock glaciers, and cirque-glacier moraines predominate at higher altitudes with the Brooks Range.

Glacial drift sheets of the Philip Smith Mountains and Chandalar quadrangles are divisible into six units of progressively younger age. The two oldest drifts, which extend tens of kilometers beyond the range flanks, are assigned to the Anaktuvuk and Sagavanirktok Glaciations of Detterman and others (1958). Three younger drifts (Itkillik I, Itkillik II, and late Itkillik) represent substages of Wisconsin or late Wisconsin glaciation (Hamilton and Porter, 1975). The youngest drift, which occupies valley heads at altitudes generally above $1,500 \mathrm{~m}$, represents ice advances of Neoglacial age.

Physical characteristics of the glacial drifts were measured at 52 field localities where the following information was obtained: (1) frequency, size, and lithology of surface boulders; (2) depth of etching, pitting, and oxidation rinds on surface boulders; (3) widths of moraines, angles of flanking slopes, and relief along crests; (4) size, frequency, and stability of kettles; (5) development of soliffuction sheets, patterned ground, and vegetation cover; (6) width, depth, and character of axial stream incision; and (7) depth and intensity of soil formation. Preliminary analyses of our data show that the physical character of the drifts is strongly affected by local loess history in addition to relative age. Moraines of the oldest Itkillik substage (Itkillik I) show the differential effects of loess deposition most strongly. These moraines tend to be sharp crested and bouldery along valley flanks, but are traceable into progressively more subdued features toward valley centers. Soil pits and borings show that thick loess blankets overlie the Itkillik I deposits along the floors of many valleys. Pre-Itkillik drifts tend to have relatively uniform loess cover; drifts younger than Itkillik I usually lack appreciable loess blankets.

All of the physical parameters listed above are useful indicators of relative age and hence valuable for correlation of drifts within this part of the Brooks Range. Some properties such as develop- ment of soliffuction sheets and etching of surface boulders change relatively rapidly and hence are valuable for distinguishing substages of Itkillik glaciation. Other characteristics such as width of axial stream incisions and depth of oxidation rinds on resistant clasts change more slowly and are useful for distinguishing between the Anaktuvuk, Sagavanirktok, and Itkillik Glaciations. Certain characteristics such as large nonsorted polygons on Itkillik II deposits appear to be diagnostic of specific drifts.

Landslide deposits at higher altitudes within the Brooks Range are far more extensive than hitherto reported, but many of the landslides appear to be of late-glacial age and are inactive today. In several cases, landslide deposits are markedly kamelike in character and probably were deposited atop stagnating glacial ice during latest Itkillik time. Other landslides have been dissected by early Holocene stream downcutting. Assessment of the origin and history of highaltitude glacial, landslide, and talus features in this part of the Brooks Range is complicated by widespread rock glacier activity that has significantly altered their positions and surface character.

\section{REFERENCES CITED}

Detterman, R. L., Bowsher, A. L. and Dutro, J. T., Jr., 1958, Glaciation on the Arctic Slope of the Brooks Range, northern Alaska: Arctic, v. 11, no. 1, p. 43-61.

Hamilton, T. D., and Porter, S. C., 1975, Itkillik glaciation in the Brooks Range, northern Alaska: Quaternary Research, v. 5 , no. 4 (in press).

Displacement of Yukon-derived sediment from northern Bering Sea to southern Chukchi Sea during the Holocene By C. Hans Nelson and Joe S. Creager ${ }^{1}$

From the time Shpanberg Strait (between St. Lawrence Island and the Yukon Delta) opened about 12,000 B.P. until Norton Sound was flooded by rising sea level about 9,500 B.P., as much as 63 percent of the sediment load of the Yukon River bypassed northern Bering Sea to be deposited in the southern Chukchi Sea (fig. 3 (4), (5), (26)). After flooding, Yukon sediment began accumulating in Norton Sound, but significant deposition may not have begun until the present Yukon subdelta began to form in southern Norton Sound about 5,000 B.P. Even now, 17-41 percent of the Yukon load appears to leave northern Bering Sea as the continual strong northward circulation of Alaskan Coastal Water advects some of the Yukon

\footnotetext{
'Department of Oceanography, University of Washington.
} 
sediment plume and carries masses of sediment intermittently resuspended by storms to the Chukchi Sea. Since Shpanberg Strait opened, about 40-50 percent of the Yukon sediment appears to have accumulated in a thick blanket of Holocene sediment found in the southern Chukchi Sea. This major displacement of sediment has important implications for models of advective transport on shelves, for paleogeographic reconstructions of sedimentary environments in epicontinental seas and for development of nonsubsiding deltas.

"New" volcanoes in the Aleutian volcanic arc

By Thomas P. Miller and Robert L. Smith

Two previously unreported volcanoes in the Aleutian volcanic arc were found this past summer (1975) during geothermal reconnaissance investigations. The first discovered, Mount Kialagvik (fig. 2 (35)), located on the Alaska Peninsula about $130 \mathrm{~km}$ east-northeast of Port Heiden, appears to be a dacitic dome with associated dacitic ash flows. The relative lack of erosion of the unconsolidated ash flows suggests a very young age, perhaps a few thousand to a few tens of thousands of years, similar to the age of other nearby dacitic volcanoes with associated ash flows.

The other volcano, herein named Hayes Volcano (fig. 2 (22)), is at the foot of Mount Gerdine $150 \mathrm{~km}$ west of Anchorage in the Tordrillo Mountains about $90 \mathrm{~km}$ north of Mount Spurr, which had been considered the easternmost volcano in the 2,600$\mathrm{km}$-long Aleutian volcanic arc. The original vent appears to be mostly covered by the Hayes Glacier and only a remnant of unconsolidated ash fall and avalanche deposits can still be found along the margin of the glacier. Most of this material is of hornblende-biotite dacite composition. This volcano is the probable source of the air-fall ash that immediately underlies surface vegetation in the upper Susitna River drainage and may be the source of some of the air-fall ash found in the general Anchorage area. The volcano is thought to be very young because the unconsolidated avalanche deposits occur in an environment where a considerable amount of erosion takes place and the associated air-fall ash occurs close to the surface.

Reconnaissance geochemistry and tectonics of GuIf of Alaska greenstones

By Gary R. Winkler

Major oxide and minor element abundances demonstrate that greenstones within Mesozoic and Paleogene flyschlike terranes along $1,500 \mathrm{~km}$ of the Gulf of Alaska continental margin are almost entirely tholeiitic basalt. From Sanak Island (False Pass quadrangle) on the west to Yakutat (Yakutat quadrangle) on the east (fig. 1), the greenstones are nearly indistinguishable chemically and have compositional characteristics of ocean-floor basalt. Volumetrically minor alkalic basalts are limited to Oligocene intrusive and pyroclastic phases of volcanic activity that appear to be generated from an unrelated magma suite.

Discrimination between Gulf of Alaska basalt types by major oxide percentages or ratios is equivocal, perhaps partly owing to the range in analyzed samples from nearly fresh basalt to zeolite and greenschist facies metavolcanic rocks. The minor elements, $\mathrm{Ti}, \mathrm{Y}$, and $\mathrm{Zr}$, are less sensitive to changes imposed by alteration or metamorphism. Their abundances in Gulf of Alaska greenstones are comparable to those of basalts known to have been erupted in oceanic tectonic settings.

Intercalation of oceanic tholeiites and terrigenous sedimentary rocks in the Mesozoic and Paleogene terranes of coastal southern Alaska suggests that oceanic crust repeatedly was accreted to the continent along with prisms of flysch-perhaps partly as a detached substrate for flysch sequences, but more typically within them. Widely variable basalt thicknesses may indicate that local edifices in particular were subject to detachment from oceanic crust and incorporation into the accretionary continental margin. The younger alkalic basalts may reflect local oceanic island formation subsequent to tectonic thickening of the continental margin.

Uplift rates of marine terrace sequences in the Gulf of Alaska By Travis Hudson, George Plafker, and Meyer Rubin

Work on Middleton Island (fig. 3 (18)) after the Alaska Earthquake of March 27, 1964, revealed that the sequence of marine terraces that were related to Holocene tectonic uplifts that probably accompanied major earthquakes. Radiocarbon dating of driftwood and peat from five of these terraces established an average uplift rate of 1 $\mathrm{cm} / \mathrm{yr}$ for about the past 4,500 years and that the interval between major earthquake-related uplifts was 500 to 1,300 years (Plafker and Rubin, 1967, 1969, and unpublished data). The results from Middleton Island suggested that geochronologic studies of other marine terraces in the Gulf of Alaska could provide significant new quantitative 
data on the Holocene tectonic history of this part of the State.

The new studies reported on here are the results of radiocarbon dating of material from two additional marine terrace sequences that are located between Cape Yakataga and Icy Bay (fig. 3 (20)) and in the vicinity of Lituya Bay (fig. 3 (22) ). Most of the radiocarbon dating is of peat accumulations on the raised surfaces; a few age determinations are of wood. The peat accumulations were sampled with a modified Livingston corer and the deepest peat recovered, which is assumed to be the oldest material from each core, has been dated. The biggest problem in this approach to dating of the surfaces is the unknown nature of the peat stratigraphy. Not only is it uncertain whether or not the peat began accumulating soon after emergence of the terrace but it is also uncertain whether or not the deepest peat recovered is actually the basal peat in the sampled section. By taking many cores at many different localities, these difficulties are partially overcome, and it appears that the actual age of many of the terraces has been approximated by the oldest dated peat samples.

The preliminary results of the radiocarbon dating are summarized in figure 6 . The data for the Lituya Bay terraces indicate an uplift rate $(0.9$ $\mathrm{cm} / \mathrm{yr}$ ) close to that determined at Middleton Island $(1 \mathrm{~cm} / \mathrm{yr})$. The data for the terraces between Cape Yakataga and Icy Bay are much less satisfactory, but suggest an uplift rate $(0.5 \mathrm{~cm} / \mathrm{yr})$ about half of that in the other two areas. All of these uplifts are relative to present mean sea level and no adjustments for eustatic or possible isostatic changes have yet been made. The isostatic adjustments are expected to be small, if any, but eustatic changes would appreciably affect the height of the older terraces ( $>6,000$ years). If the elevations of these older terraces were adjusted for Holocene sea level changes, the calculated uplift rates would be even greater than that determined from the data summarized in figure 6 and the Yakataga-Icy Bay uplift rate might be roughly comparable to that in the other two areas. In any case, the observed rates are exceptionally high when compared with uplifted marine terrace sequences elsewhere in the world.

All of the areas studied are presently tectonically active and have been so throughout Pliocene-Pleistocene time but the general tectonic regimes differ: Middleton Island is near the eastern termination of the Aleutian Trench, the

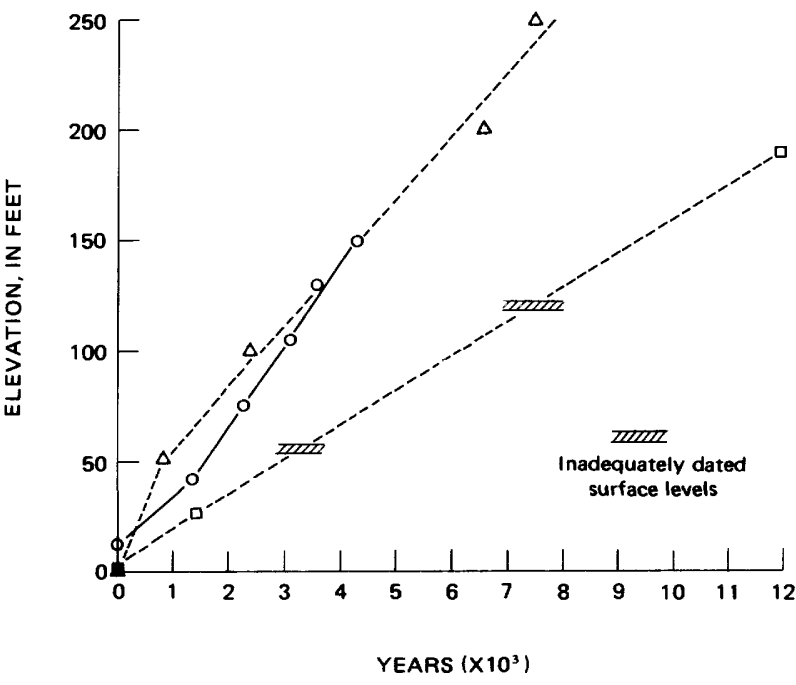

Figure 6.-Preliminary results of radiocarbon dating of marine terrace sequences between Cape Yakataga and Icy Bay $(\square)$, in the vicinity of Lituya Bay ( $\Delta$ ), and on Middleton Island ( $O$ ). Middleton Island data from Plafker and Rubin (1967 and unpublished).

Lituya Bay area is adjacent to the active strikeslip Fairweather fault, and the Yakataga-Icy Bay area is in a transition zone between these two different tectonic provinces. Because of these differences in tectonic regime, it seems unlikely that the uplift in each of the areas is due solely to regional tectonic deformation. This conclusion is supported by the general lack of correlation of terrace heights between the three areas (fig. 6). But because documented historical earthquakes have always been accompanied by vertical displacements in all these areas (Tarr and Martin, 1912; Tocher, 1960; and Plafker and Rubin, 1967), it does appear that diastrophism plays a major role in the origin of the raised surfaces. The most obvious similarity in tectonic setting between the three areas is that each is located on the flank of a growing anticlinal structure. It is therefore possible that the development of the raised surfaces is actually related to the growth of these relatively local structures. If this is so, marine terrace development in the Gulf of Alaska is a rather local phenomenon dependent chiefly upon the coincidental location of an actively growing fold in or near the eroding coastal zone. As a consequence, neither lateral continuity nor height correlation is to be expected between terrace sequences.

The linear trends of radiocarbon dates (fig. 6) show that a relatively constant rate of uplift has affected at least the Middleton Island and Lituya 
Bay areas during the past several thousand years, but that the rate for the most recent wave-cut surfaces diverges from the longer term trends in both cases. This divergence from the linear age relative to elevation trends may provide important clues to the nature and present status of diastrophism in the vicinity of the terrace sequences. The existence of the terraces alone indicates that uplift over the short term is somewhat spasmodic. The data for Middleton Island could be interpreted to mean that the most recent uplift in that area has not kept pace with the longer term rates and that further uplift is overdue (Plafker, 1972, p. 916917). The data for the Lituya Bay area could indicate just the opposite relation; uplift of the younger terraces has exceeded the longer term rate and either the overall uplift rate is increasing or relative stability is to be expected in this area.

\section{REFERENCES CITED}

Plafker, George, 1972, Alaskan Earthquake of 1964 and Chilean Earthquake of 1960; Implications for arc tectonics: Jour. Geophys. Research, v. 77, no. 5, p. 901-925.

Plafker, George, and Rubin, Meyer, 1967, Vertical tectonic displacements in south-central Alaska during and prior to the great 1964 earthquake: Jour. Geosciences, Osaka City Univ., v. 10, art. 1-7, p. 53-66.

1969, Tectonic implications of Late Cenozoic uplift and deformation at Middleton Island, Alaska: Paper presented at Internat. Quaternary Assoc. Cong., Paris.

Tarr, R. S., and Martin, Lawrence, 1912, The earthquakes at Yakutat Bay, Alaska in September, 1899: U.S. Geol. Survey Prof. Paper 69, 135 p.

Tocher, Don, 1960, The Alaska Earthquake of July 10, 1958; Movement on the Fairweather fault and field investigation of southern epicentral region: Seismol. Soc. America Bull., v. 50 , no. 2 , p. 267-292.

Structural style of part of the Outer Continental Shelf in the Gulf of Alaska Tertiary Province

By Terry R. Bruns and George Plafker

During September and October of 1974, the U.S. Geological Survey collected $6,575 \mathrm{~km}$ of marine single-channel seismic reflection data in the eastern Gulf of Alaska between Yakutat Bay and Montague Island (fig. 3 (19)). Preliminary interpretation of the data indicates that the Outer Continental Shelf (OCS) of the eastern Gulf of Alaska Tertiary Province (GATP) is geologically complex, being constituted of several areas of markedly different structural styles. Approximately 30 structural highs have been delineated on the OCS, with an apparent increase in complexity from east to west across the GATP (Bruns and Plafker, 1975).
Between Cross Sound and Icy Bay (fig. 3 (21)), there is only one structural high, the Fairweather Ground, a large shelf-edge arch that roughly parallels the coast. Hard deformed rocks, probably of Late Cretaceous to early Tertiary age, crop out in the core of the arch. The rest of the area is underlain by a broad basin whose axis lies near the coast. Between Icy Bay and Kayak Island the shelf is underlain by two types of structures. The first type is a series of large asymmetric linear folds as much as $38 \mathrm{~km}$ long by $6.5 \mathrm{~km}$ wide that trend obliquely across the shelf, roughly from northeast to southwest. These structures are apparently more open and less complex than those on the adjacent land areas, although some of the offshore anticlines are bounded on the southeast by northwest-dipping overthrust faults. The second type is a broad shelf-edge arch between Kayak Island and the Bering Trough, trending parallel to the coast and with very gentle surface dip. Between this arch and the coast is a broad basin as much as $95 \mathrm{~km}$ wide within which there may be some local unwarped areas. The OCS in a zone extending from Kayak Island to Middleton Island consists of complex structures trending roughly northeast-southwest, subparallel to these two islands and to the Aleutian Trench. Structural highs tend to be asymmetric and bounded by thrust faults on their southeast limbs. Uplift and deformation are greater than on the Icy Bay structural trend features, and the crests of many of the highs appear to have undergone extensive erosion and truncation exposing complexly deformed Tertiary rocks at the sea floor. Northwest of Middleton Island there are two large northwest-southeasttrending structural highs separated by a deep basin. These structures, which are divergent from the Icy Bay and Kayak-Middleton trends, show severe deformation on the flanks, and no structure is resolvable within the cores. Middleton Island lies on the northwest flank of a large northeasttrending anticline and appears to be separated from the northwest-trending structures by a relatively deep basin. Shoreward of the KayakMiddleton structural zone, acoustic basement appears to be high, and structure is not well defined with the marine geophysical data. This area includes much of the Hinchinbrook Seavalley, Tarr Bank, and the Copper River Delta.

Sound penetration on the seismic reflection profiles is generally less than $1 \mathrm{~s}$ (one-way time) and is probably largely within late Miocene and 
younger rocks. By analogy with the adjacent onshore geology, the deeper structure offshore may be markedly more complex than observed surface structure.

\section{REFERENCE CITED}

Bruns, T. R., and Plafker, George, 1975, Preliminary structural map of part of the offshore Gulf of Alaska Tertiary Province: U.S. Geol. Survey open-file map 75-508.

The Border Ranges fault system in the Saint Elias Mountains and Alexander Archipelago

By George Plafker, D. L. Jones, Travis Hudson, and H. C. Berg

The Border Ranges fault (BRF), one of the major fault systems in southern Alaska, represents a late Mesozoic plate boundary that juxtaposes regionally metamorphosed upper Paleozoic rocks on the north against predominantly upper Mesozoic deep marine rocks for more than $1,000 \mathrm{~km}$ in the northern Kodiak, Kenai, and Chugach Mountains (MacKevett and Plafker, 1974). New data suggest that the BRF system continues an additional 700 $\mathrm{km}$ southeastward from the Chugach Mountains to Chatham Strait, where it consists of two major segments, the Fairweather segment in the Saint Elias Mountains and the Archipelago segment between Cross Sound and Chatham Strait (fig. 7).

The Fairweather segment of the BRF, which coincides in Alaska with the Fairweather fault (Plafker, 1967), is linear and probably nearly vertical. It is marked by broad shear zones containing abundant breccia and gouge along which a prominent linear topographic trough has been developed. The Archipelago segment of the BRF has a more variable dip than the Fairweather segment as indicated by its irregular trace and by geologic relations across the fault, including: (1) direct observation of the fault zone at two localities on northern Baranof Island, where low dips were observed; (2) the occurrence of possible windows of Lower Cretaceous rocks at and near Emmons Island; and (3) the distribution of enormous allochthonous blocks that could be klippen on the Khaz Peninsula and other areas west of the fault. The linear southern part of the fault trace partly coincides with the topographically prominent trench along the younger Peril Strait fault and probably dips steeply.

Rocks above the BRF make up a thick sequence of Paleozoic mafic volcanic rocks, pyroclastic rocks, and clastic sediments with sporadic chert and marble that range from greenschist to amphibolite facies in metamorphic grade. This sequence has been extensively intruded by foliated diorite to quartz diorite plutons of Middle Jurassic age, granodioritic plutons of Early Cretaceous age, and Tertiary plutons of diverse, but dominantly felsic, composition.

On western Chichagof Island, the crystalline rocks of the upper plate are associated with, and probably overlain by, a weakly metamorphosed sequence of greenstone, limestone, chert and sandstone that crops out as a narrow band along the inferred contact of the BRF for approximately $60 \mathrm{~km}$ (fig. 7). This sequence includes the Goon Dip Greenstone and Whitestripe Marble of Triassic(?) age (Loney and others, 1975), which we suggest are correlative with the strikingly similar upper Triassic subaerial Nikolai Greenstone and nearshore marine Chitistone Limestone of the Wrangell Mountains (Armstrong and others, 1970).

Rocks below the BRF comprise a highly deformed complex of graywacke, pelite, tuffaceous pelite, and massive or pillowed greenstone, subordinate radiolarian ribbon cherts and conglomerate, and rare pods of limestone, gabbro, and thin selvages of serpentinite. Interspersed with the bedded rocks are melanges composed of blocks of competent rocks to several kilometres in greatest dimension enclosed in a pervasively sheared matrix of pelite or tuffaceous pelite. Most of these rocks are of deep marine origin and are weakly metamorphosed to grades ranging from zeolite to low greenschist facies. The sequence is cut by widespread dioritic to granitic plutons of Cretaceous(?) and Tertiary age. The age of the bedded sequence probably ranges from Valanginian to Campanian based on the occurrence of upper Valanginian radiolarians in the pelagic chert (Emile Pessagno, written commun., 1975) and sparse Hauterivian and Campanian megafossils in the clastic sequence at localities shown on figure 7 . Known or suspected "exotic" or externally derived blocks in the melange have yielded older fossil and radiometric ages that range from late Triassic(?) to Berriasian. The lower plate complex includes all of the Yakutat Group and unnamed volcanic rocks (Mzv) on the mainland (Plafker, 1967), and the Kelp Bay Group, Khaz Formation, Waterfall Greenstone, Sitka Graywacke, and related rocks of the Alexander Archipelago (Loney and others, 1975). 


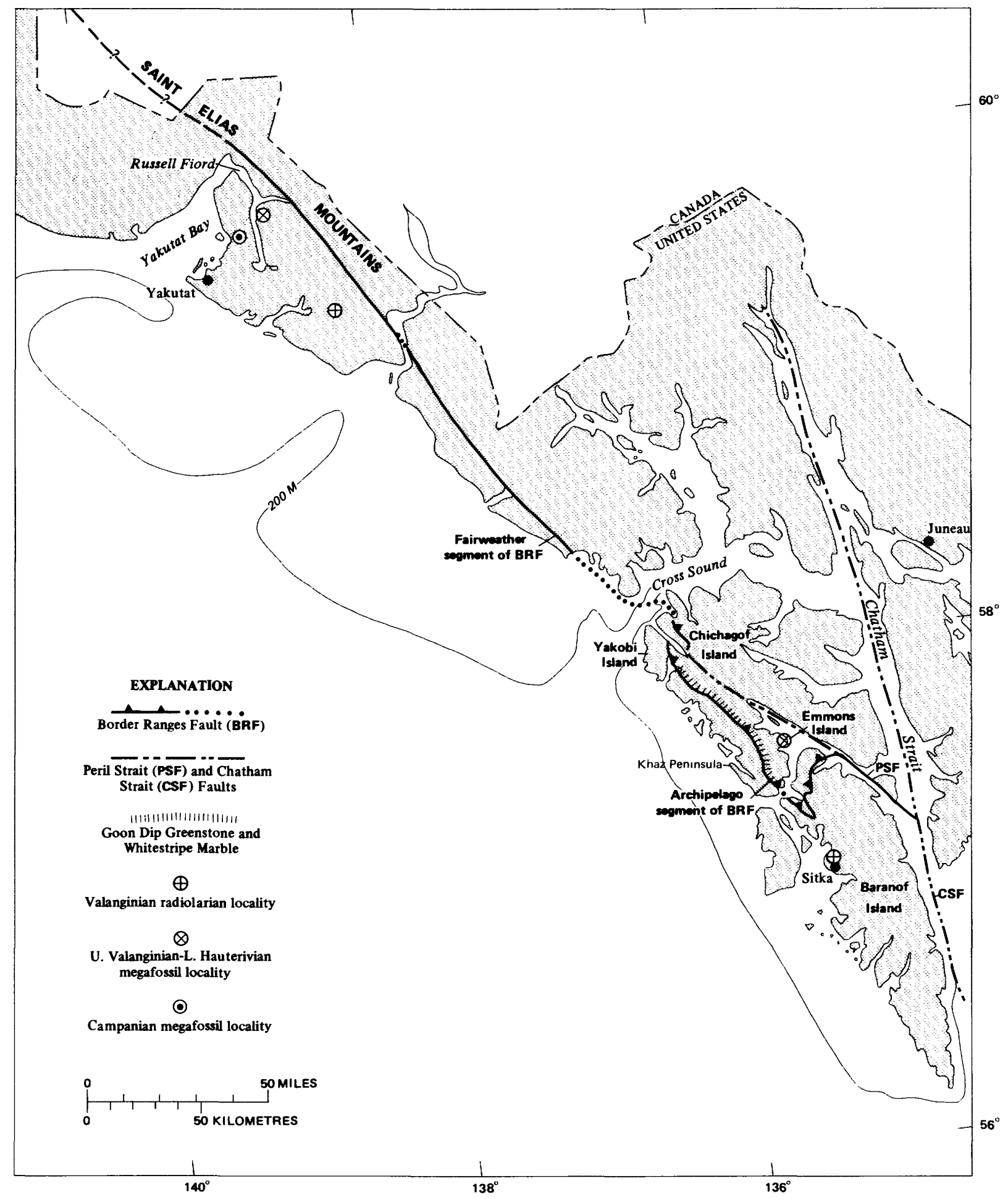

FIGURE 7.-Index map showing the location of the Border Ranges Fault (BRF) and its major segments in the Saint Elias Mountains and Alexander Archipelago, other major faults, and important fossil localities. 
Rocks below the BRF in the Saint Elias Mountains and Alexander Archipelago are interpreted to include dismembered fragments of oceanic crust, pelagic sediments, and a turbidite sequence that were deformed by subduction that probably commenced during Early Cretaceous time and continued at least into the Campanian. Concurrently, an andesitic arc contributed abundant volcaniclastic detritus to the sequence. Extensive granitic batholiths of Early Cretaceous age in the southeastern part of the area (Loney and others, 1975) may be remnants of that arc. Large "exotic" melange clasts might have been incorporated by tectonic disruption and submarine sliding of older rocks exposed along the inner wall of the trench. The entire complex below the BRF was welded to the continental margin by widespread deformation, metamorphism, and plutonism in the Late Cretaceous(?) and Tertiary.

During the Cenozoic, the linear topographically prominent parts of the BRF thrust system, including all of the Fairweather segment and the southern part of the Archipelago segment, have been reactivated as dominantly right-lateral strike-slip faults. Offset of the BRF contact by the younger Peril Strait fault in Lisianski Inlet indicates that there has been no more than $11 \mathrm{~km}$ net rightlateral strike-slip displacement on the Peril Strait fault since the Late Cretaceous; total right-lateral slip on the Fairweather fault is not known, but is undoubtedly much greater.

\section{REFERENCES CITED}

Armstrong, A. K., MacKevett, E. M., Jr., and Silberling, N. J., 1970, the Chitistone and Nizina Limestones of the southern Wrangell Mountains, Alaska in Geological Survey research 1969: U.S. Geol. Survey Prof. Paper 650-D, p. D49-D62.

Loney, R. A., Brew, D. A., Muffler, L. J. P., and Pomeroy, J. S., 1975, Reconnaissance geology of Chichagof, Baranof, and Kruzof Islands, southeastern Alaska: U.S. Geol. Survey Prof. Paper 792, 105 p.

MacKevett, E. M., Jr., and Plafker, George, 1974, The Border Ranges fault in south-central Alaska: U.S. Geol. Survey Jour. Research, v. 2, no. 3, p. 323-329.

Plafker, George, 1967, Geologic map of the Gulf of Alaska Tertiary province, Alaska: U.S. Geol. Survey Misc. Geol. Inv. Map I-484, scale 1:500,000.

\section{NORTHERN ALASKA}

Seabed morphology adjacent to an "island" of grounded ice in the Arctic Ocean northwest of Point Barrow By L. J. Toimil and Arthur Grantz

The seafloor adjacent to the grounded ice forma- tion known as "Katie's Floeberg," located some $160 \mathrm{~km}$ northwest of Point Barrow, was investigated utilizing side-scan sonar, precision fathometer, and seabed sediment samplers. The survey was conducted in August 1974 from the U.S. Coast Guard Cutter BURTON ISLAND. Aerial observations made during the survey confirmed previous satellite image interpretations by Stringer and Barrett (1975) and Kovacs and others (1975) that the formation was not an "ice island," that is, a large tabular iceberg of glacial shelf ice, but rather an assemblage of linear and curvilinear pressure ridges and ice floes some $15 \mathrm{~km}$ long and $5 \% 4 \mathrm{~km}$ wide (fig. 8). The floeberg, centered at $72^{\circ} 03^{\prime} \mathrm{N}$., $162^{\circ} 50^{\prime} \mathrm{W}$., grounded on or near the apex of a broad regional shoal that extends over much of the northeastern Chukchi Shelf.

Facsimile side-scan sonar and bathymetric records obtained in a narrow lead along the floeberg's southwest-to-northeast-trending western margin show extensive modification of the seabed sediments by currents and gouging by deep keels of moving ice. Water depths along the survey varied between 27 and $31 \mathrm{~m}$, the bottom gradually shoaling to the northeast. Distinct facies changes, defined by sand ripple fields and contrasts in acoustic reflectivity, show the influence of bottom currents and imply a general coarsening of sediments toward the floeberg's northern end. Here, disruption of the seabed by ice gouging is most intense. The gouges characteristic of those plowed by multikeeled pressure ridges (Reimnitz and Barnes, 1974), are more numerous, wider, and more complex than to the south. Some are more than $100 \mathrm{~m}$ wide and cut as deeply as $1.5 \mathrm{~m}$ into the seafloor sediments.

Ice gouging of the seafloor sediments tends to resuspend the finer sediment fractions, making them available for transport by bottom currents. This process tends to concentrate the coarser fractions as lag deposits. The sharp decrease in the intensity and depth of ice gouging and in the width of individual gouges to the southwest along the survey track, where water depths exceed $29 \mathrm{~m}$, may reflect the predominant southwest drift of the winter ice pack past the floeberg and across the regional shoal upon which it rests. The direction of predominant drift was inferred from ice pack deformation recorded on ERTS I imagery. In this setting, deep drift ice in the pack and any deepkeel pressure ridges that may have formed along the stoss side of the floeberg would be held on the 
crest or on the northeast side of the shoal until sufficiently thinned by ablation or abrasion to scrape or float across it. The keels would then float over the southern part of the shoal (water depth $>29 \mathrm{~m}$ ) without extensively raking the seafloor. The depth, width, and frequency of gouges can be expected to be anomalously high on the north side of the floeberg, and probably everywhere along the crest and north side of the shoal. The results of our preliminary analysis, and the recognition that similar ice formations occur on shoals elsewhere in the Chukchi Sea and vicinity (Kovacs and others, 1975), suggest that the anomalously coarse sediments found on many shoals on the Chukchi Shelf (Creager and McManus, 1967) may in part be the result of winnowing initiated by the seafloor gouging produced by massive ice groundings.

\section{REFERENCES CITED}

Creager, J. S., and McManus, D. A., 1967, Geology of the floor of Bering and Chukchi Seas-American studies, in Hopkins, D. M., ed., The Bering Sea land bridge: Stanford, Calif., Stanford Univ. Press, p. 7-31.

Kovacs, Austin, Gow, A. J., and Dehn, W. F., 1975, Islands of grounded sea ice: Internat. Conf. on Port and Ocean Engineering under Arctic Conditions, 3d, Fairbanks, Alaska, Aug. 1975, (in press).

Reimnitz, Erk, and Barnes, P. W., 1974, Sea ice as a geologic agent on the Beaufort Sea Shelf of Alaska, in Reed, J. C., and Sater, J. E., eds., The coast and shelf of the Beaufort Sea: Arctic Inst. North America, p. 301-351.

Stringer, W. J., and Barrett, S. A., 1975, Katie's Floeberg: The Northern Engineer, v. 7, no. 1, p. 26-30.

Possible solid gas hydrate and natural gas deposits beneath the continental slope of the Beaufort Sea

By Arthur Grantz, Gary Boucher, and Olive Therese Whitney

The continental slope north of Alaska (fig. 3 (1), $(2),(4))$ is underlain by an unusually strong seismic reflector that crosses local bedding planes at many places and that mimics, or simulates, the bathymetry of the seafloor, yet lies some 100-300 $\mathrm{m}$ beneath it. This bottom simulating reflector (BSR) occurs only where the sea is deeper than $400-600 \mathrm{~m}$ and extends beneath the deepest waters traversed at $2,500+\mathrm{m}$. The BSR was identified beneath some 60 percent of our seismic lines (Grantz and others, 1974) in waters deeper than $400-600 \mathrm{~m}$, an area of continental slope greater than $7,500 \mathrm{~km}^{2}$. Its total extent is of course much greater, and it may well encompass the entire Arctic basin where it is deeper than $400-600 \mathrm{~m}$.

The BSR is most strongly developed beneath bathymetric highs and weakest, and indeed often absent, beneath bathymetric lows. In a few places where it is particularly well developed beneath highs, the underlying reflectors are bowed downward. Preliminary analysis of seismic signatures suggests that reflections from the BSR are reversed in polarity. Taken together, these observations suggest that the BSR is produced by a zone of free gas in the sediments immediately beneath an impervious cap. Because the BSR lies at the approximate pressure-temperature boundary at which solid gas hydrates of methane and some multicomponent natural hydrocarbon gases are in equilibrium with these gases in water, we postulate that the putative free gas is trapped beneath an impermeable cap of sediment cemented with hydrate.

The BSR is thought to mimic the seafloor, which is essentially an isothermal surface, because the stability field of solid gas hydrate is more strongly a function of temperature than of pressure under the prevailing conditions. This relation is thought to account for the fact that the base of the BSR is structurally high beneath bathymetric highs. These highs apparently acted as structural traps for free hydrocarbon gases generated by biologic or thermal processes from organic matter in the subsea sediments, or leaked from deeper reservoirs. Such trapping could explain the fact that the BSR is most strongly developed beneath bathymetric highs.

The possibility exists that very extensive deposits of natural gas underlie the shallow BSR beneath Alaska's Arctic continental slope. Much additional data, including conclusive proof that solid gas hydrate and free gas are indeed present, will be needed before we can even guess at the magnitude of the natural gas resource that may be present.

\section{REFERENCE GITED}

Grantz, Arthur, McHendrie, A. G., Nilsen, T. H., and Yorath, C. J., 1974, Seismic reflection profiles on the continental shelf and slope between Bering Strait and Barrow, Alaska, and Mackenzie Bay, Canada: U.S Geol. Survey open-file report, 49 sheets.

Sediment-ice interaction in the Beaufort Sea By Peter W. Barnes and Erk Reimnitz

The geologic action of ice is a major factor in the marine geologic and sedimentologic environment of the Beaufort Sea shelf (fig. 3 (2)). Erk Reimnitz and Peter Barnes working together over the past 5 years have developed a basic framework for 


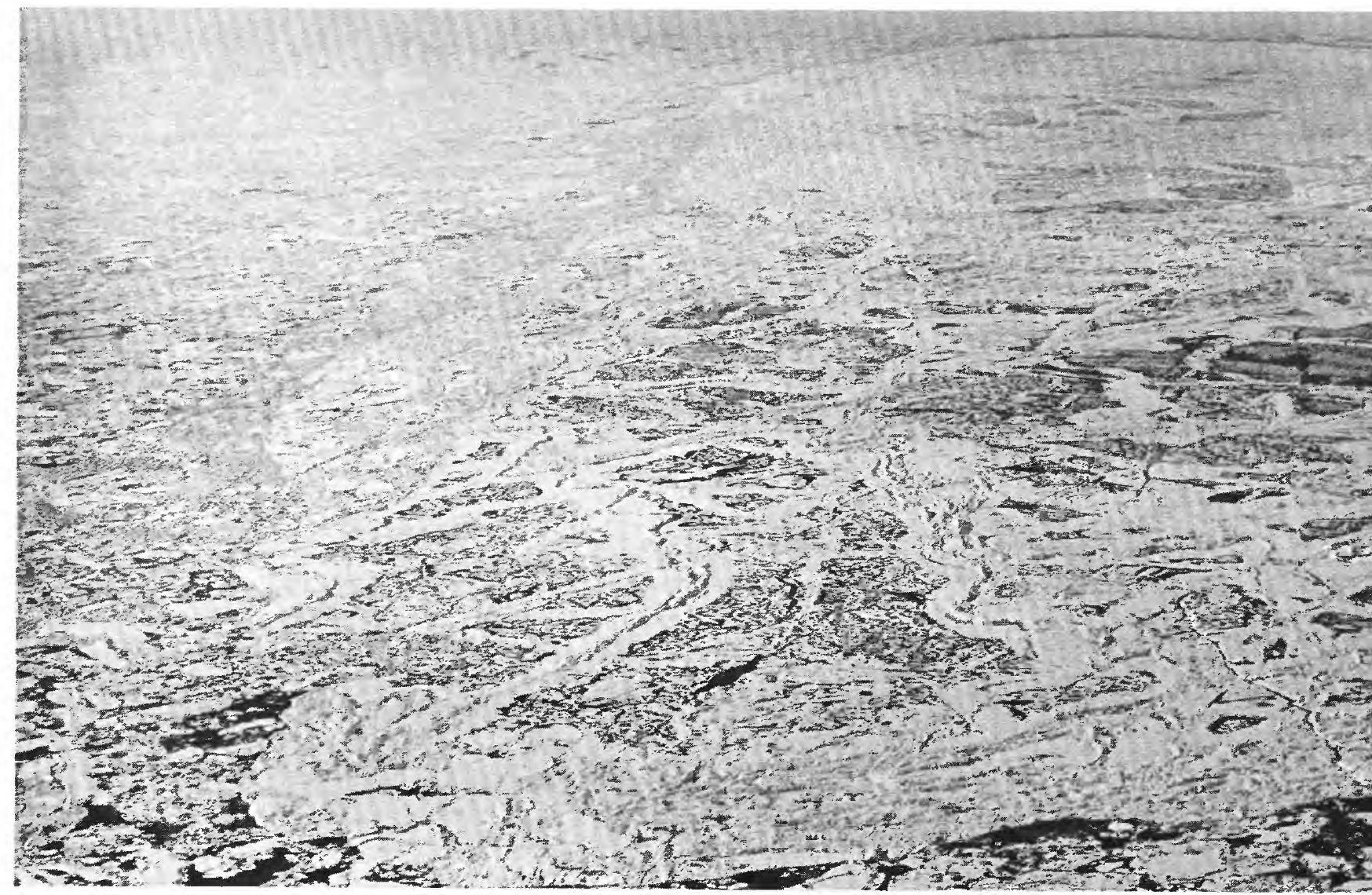

FIGURE 8.- "Katie's Floeberg," a complex assemblage of grounded pressure ridges and intervening ice floes in the Arctic Ocean semblage, elongate in the view direction, was approximately $15 \mathrm{~km}$ long and $5 \% / 4 \mathrm{~km}$ wide. Photo

geologic processes and the related sedimentologic record over the entire shelf width (Barnes and Reimnitz, 1974; Reimnitz and Barnes, 1974). The processes are related to both the hydrologic regime and the ice dynamics. Drifting and stationary ice interacts with the surface sediments and currents of the arctic shelf, forming a series of morphologies and sedimentary structures that are related to water depth, ice type, and distribution, and to the season of the year.

The shear zone between the fast ice covering the inner shelf and the pack ice on the Arctic Ocean imposes severe restrictions to the offshore developments on the Beaufort Sea shelf. Processes acting within this zone, and factors controlling its location, are of great concern to industry. Reimnitz and Barnes have utilized ERTS-1 and NOAA satellite imagery in a study of this major ice feature over several seasons. The mid-winter shear line, marking the seaward boundary of the relatively undisturbed fast-ice belt, was found to form between the 10-and 20-m depth contours along the north coast of Alaska (fig. 9), that is apparently not controlled by concentrations of large grounded ice 


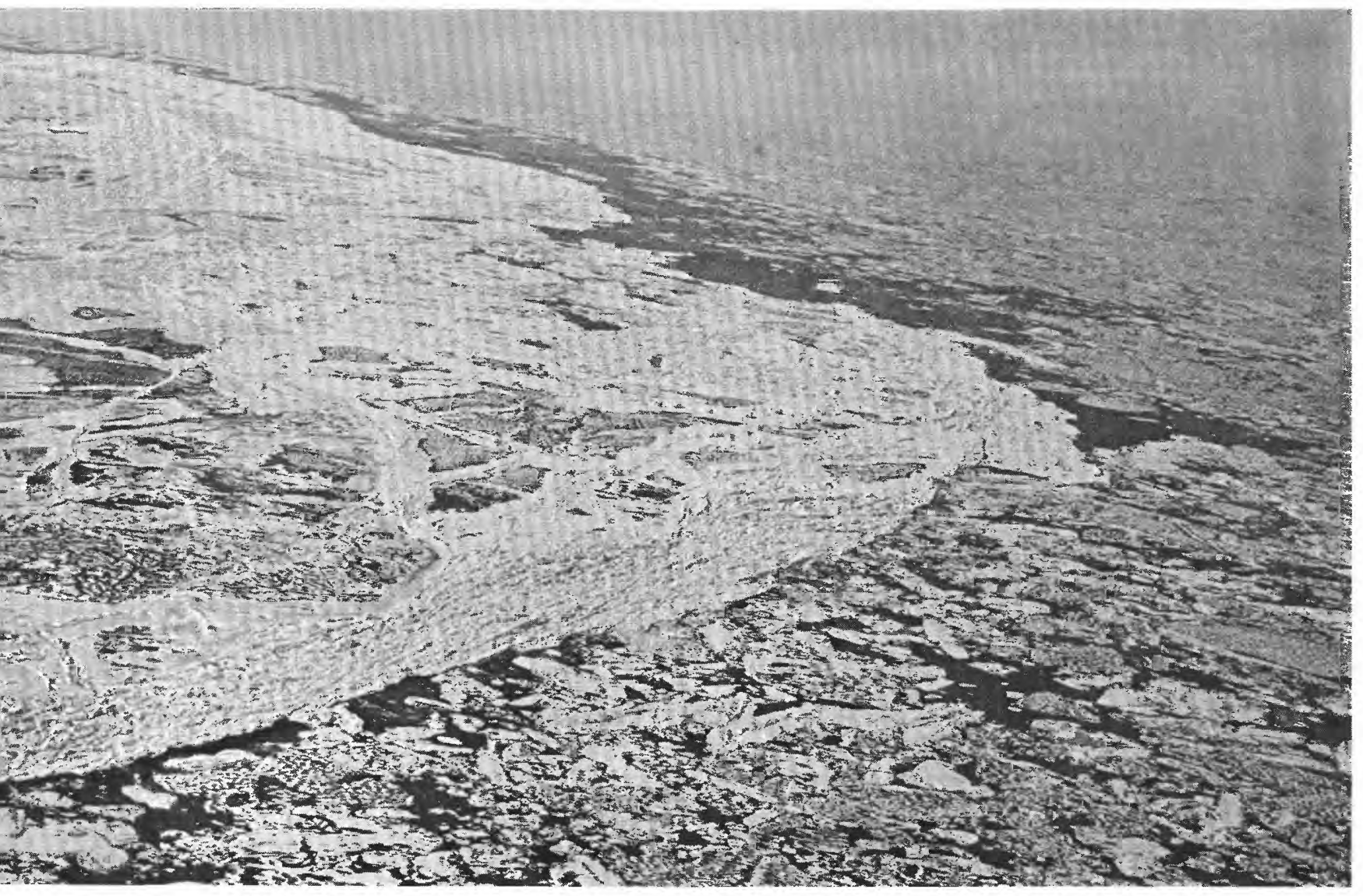

$160 \mathrm{~km}$ northwest of Point Barrow, as viewed from the northeast from an altitude of about $500 \mathrm{~m}$ on August 21, 1974 . The asgraph by Capt. Robert G. Moore, Commanding Officer, U.S. Coast Guard Cutter BURTON ISLAND.

during the preceding freeze-up but by shoals and coastal configuration. Seaward of this initial shear line is the "shear zone" in which the ice is intensely deformed, showing a dense pattern of major pressure ridges. The "shear zone" is characterized by periods of relative stability interrupted by events during which ice is moving westward at rates as high as $20 \mathrm{~km}$ per day. Major pressure ridges form during such movements, and their keels in many cases extend to the seafloor, plowing the bottom. Eventually the pressure ridges become so firmly grounded that the ice in the shear zone is strongly resistant to further deformation, thereby causing a seaward extension of the fast ice during the course of the winter. Along relatively straight stretches of coastline this seaward extension may cover a zone $20-25 \mathrm{~km}$ wide, with new shear lines forming farther seaward. In monitoring several periods of ice deformation, it was found that the shear zone concept, which implies a gradual increase in rates of ice movement from the fast ice seaward across the continental shelf, does not apply to this area. The ice along the shear line active during any particular event is moving at 


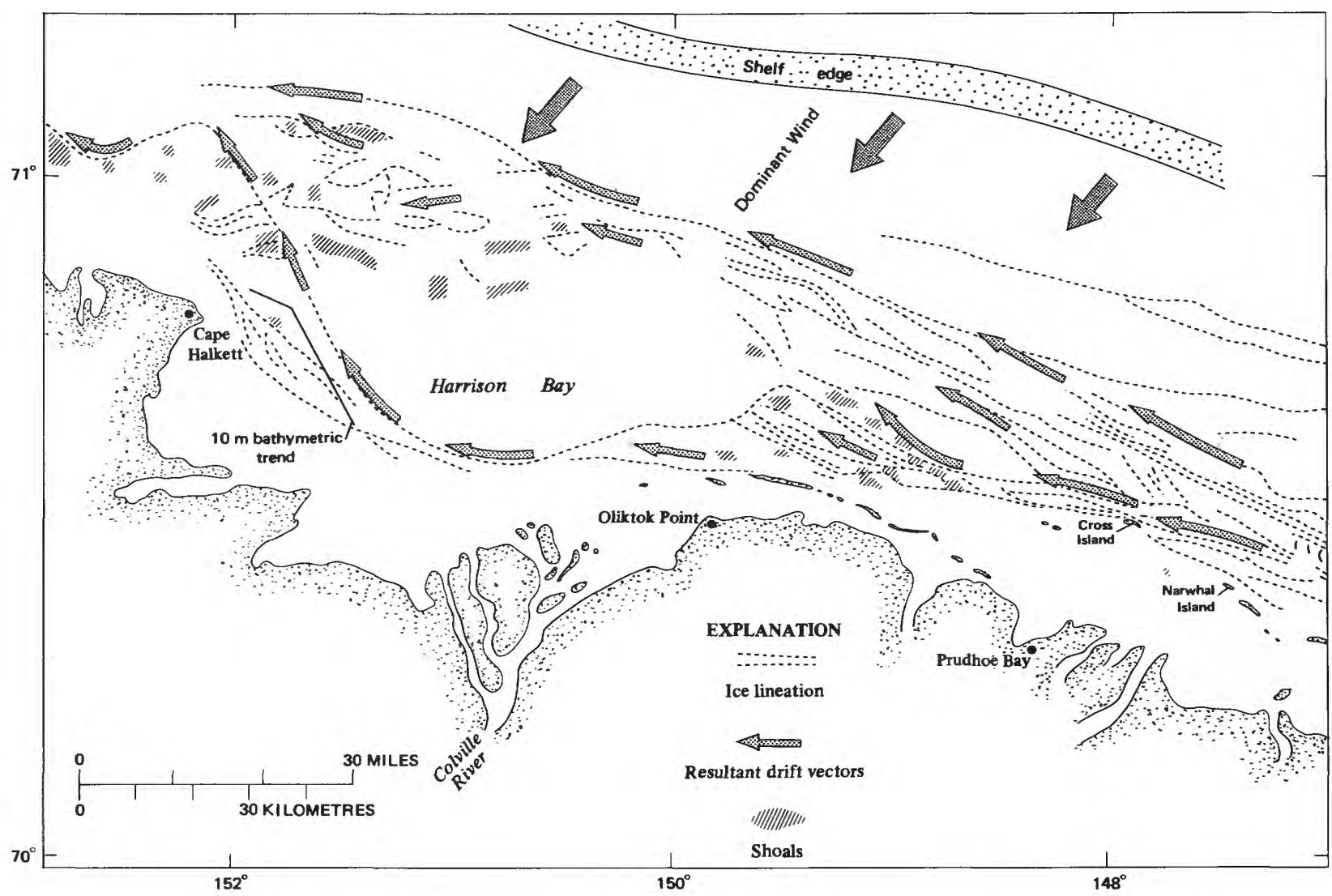

FIGURE 9.-Schematic representation of ice-bottom interactions on the shelf north of Alaska. Ice lineations are derived from 1973 ERTS-1 imagery. A concordance exists between ice lineation, drift vectors, and bathymetric shoals.

similar or even faster rates than the ice seaward of the continental shelf.

Ice within the $20-\mathrm{km}$-wide zone through which the fast ice is extended by pressure ridge accretion remains in place well into the period of general sea ice breakup during the following summer, apparently owing to the existence of firmly grounded pressure ridges in this zone.

Bottom surveys made after the sea-ice breakup show a dense pattern of seafloor gouges produced by ice in the zone of major pressure ridges on the central shelf, and a remarkably smooth bottom in the area landward of the midwinter shear line. Box cores from the same zone show that sediments are intensely mixed. Thus, the nature of the bottom deposits reflect deformational processes within the winter ice canopy above.

Close inshore the seasonal fast ice at the end of the winter is relatively undisturbed, even where in contact with the beaches. Except at shoreline promontories, the beach face after ice melt shows little evidence of winter deformation by ice. All evidence therefore indicates that most of the energy generated over the Arctic Ocean is expended on the seafloor seaward of the 10-m-depth contour off northern Alaska, not within the surf zone as on lower latitude shelves. The belt of intense ice deformation and seafloor gouging would indeed present a formidable barrier to offshore construction and shipping.

Clearly the ice action described should leave a record in the sediments that is related to both the ice regime and the hydrologic regime of the openwater summer season (fig. 10). Surface samples, diving observations, TV observations, and boxcore radiographs support this. Four facies that relate to differing dynamic environments on the shelf can be defined:

(1) Inshore (2-10 m.). River water drainage through strudel (Reimnitz and others, 1974) in the shore fast ice scours the bottom during the spring, creating circular depressions rimmed by leveelike deposits. This drainage process reworks inshore sediments. During the summer, currents and drifting ice rework the sediments along the nearshore, resulting in the develop- 


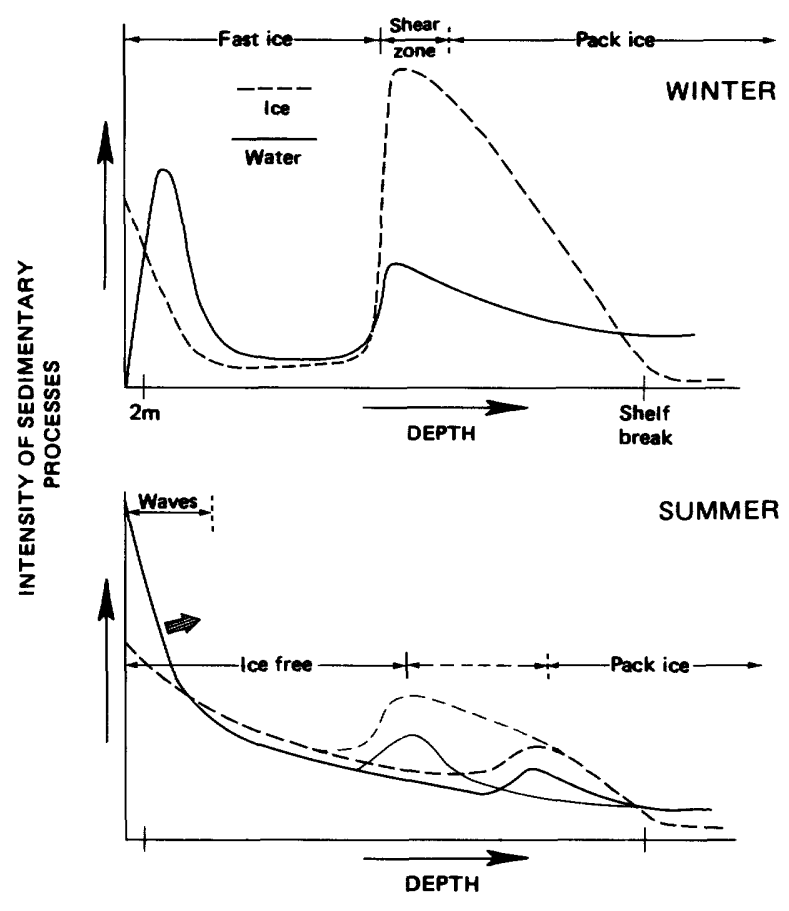

Figure 10.-Conceptual model relating intensity of agent (ice and water) to water depth, and seasonal changes in ice-water regime (after Barnes and Reimnitz, 1974).

ment of ripples, sediment ponding in scour depressions, ice gouge depressions, and grooves. Ice plowed sediments commonly are observed as metastable sediment ridges.

(2) Inner shelf (10-25 m). Inside the "shear zone" between shore fast ice and pack ice, sediments are protected from extensive ice reworking and hydrologic processes are dominant. Horizontal layering of graded sandy silts interbedded with silty clays are common in the upper meter of sediment of this depth zone. Crosslamination is notably absent, but biologic activity is abundantly evident at the sediment-water interface.

(3) Midshelf $(20-40 \mathrm{~m})$. Within the "shear zone," ice gouging creates large channellike features. Benthic fauna is absent or patchy. Cores, photographs, seismic data, and diving observations in this zone display displaced blocks of sediment, small slump features, disrupted layering, and an absence of small-scale bedding structures. Box-core and seismic data suggest a complete and total reworking of the Holocene section by ice gouging.

(4) Outer shelf $(40-130 \mathrm{~m})$. Near the shelf break older ice-gouged and ice-rafted morphologic-sedimentologic features are pres- ent. The disrupted relief is more commonly subdued, the benthic fauna is better developed, there is a fairly well-defined surface gravel layer, and the near-surface sediments are stratified.

There are many aspects of arctic shelf processes that still remain enigma. In particular, the rates of the marine geologic process and the seasonal intensity are not understood at this time and are the subject of our continuing studies.

\section{REFERENCES CITED}

Barnes, P. W., and Reimnitz, Erk, 1974, Sedimentary processes on arctic shelves off the northern coast of Alaska, in Reed, J. C., and Sater, J. E., eds., The coast and shelf of the Beaufort Sea: Arctic Inst. North America, p. 439-476.

Reimnitz, Erk, and Barnes, P. W., 1974, Sea ice as a geologic agent, in Reed, J. C., and Sater, J. E., eds., The coast and shelf of the Beaufort Sea: Arctic Inst. North America, p. 301-351.

Reimnitz, Erk, Rodeick, C. A., and Wolf, S. C., 1974, Strudel scour; a unique arctic marine geologic phenomenon: Jour. Sed. Petrology, v. 44, no. 2, p. 409-420.

Study of the gravity field of the Beaufort shelf, north coast of Alaska

By Gary Boucher

The gravity data (Hanna and others, 1974; raw data supplied by B. D. Ruppel) of the Beaufort shelf north of Alaska (fig. 3 (1)) have been studied to determine the most appropriate treatment of free-air gravity anomaly data to aid correlation between gravity data and submarine geologic structures. A regional correction, generalized from Bouguer anomaly profiles normal to the coastline, was determined in an analytic form. The regional Bouguer anomaly is attributed primarily to thinning of the earth's crust at the transition from continental Alaska to the Arctic Ocean basin (Hunkins, 1962; Worzel, 1968).

The most striking gravity feature on the continental shelf of the Beaufort Sea is a large free-air gravity high, parallel to the coastline, that extends from about $139^{\circ} \mathrm{W}$. to at least $160^{\circ} \mathrm{W}$., and probably to the west of that. In general the axis of this free-air gravity high is located near the 200-m isobath. Features of the gravity high and interpretations of the deep structure related to it have been discussed in the literature in a generalized fashion by Hunkins (1966) and by Wold and others (1970).

In order to remove from the gravity anomaly field the effects of variations in water depth, it is common to correct marine free-air gravity obser- 
vations by adding a Bouguer correction for water depth. In the Beaufort shelf area, unfortunately, the application of the Bouguer correction replaces a 50-100 mgal negative free-air contribution from water depth with an equally large positive Bouguer anomaly. Interpretation of local structures from the gravity data remains obscured by deep-seated effects that may be of little particular interest.

The present investigation was aided by recognition of a simplifying geometric relation between the gravity field and the bathymetry of the Beaufort shelf. On a polar stereographic map projection, the $200-\mathrm{m}$ isobath, the axis of the maximum free-air anomaly and the trend of the prominent Bouguer anomaly contours can all be closely approximated by circular arcs centered near $78^{\circ} \mathrm{N}$., $135^{\circ} \mathrm{W}$. This forms the basis for a polar coordinate system used to subtract the regional Bouguer anomaly from the local Bouguer anomaly data. The regional Bouguer anomaly was determined from a series of Bouguer anomaly profiles projected onto planes normal to the coastline and then superimposed using the generalized $200-\mathrm{m}$ isobath as the spatial reference. An approximation to the shape of the largest positive profile was obtained in the form of a half cycle of a sine wave with a wavelength of $400 \mathrm{~km}$. An arbitrarily chosen density value of $2.56 \mathrm{~g} / \mathrm{cm}^{3}$ was used for the Bouguer gravity correction. A two-dimensional integration was used to compute the Bouguer anomaly profiles. The gravity anomaly field resulting from subtracting the regional Bouguer correction has considerably less relief than either the free-air or Bouguer anomaly fields. The superimposed profiles for free-air and Bouguer anomalies shown in figure 11 with the shape chosen for the regional correction reveal a remarkably large variation even after the corrections for water depth have been made.

Interpretation of the gravity map obtained is not yet complete, but a number of interesting results have been obtained. It appears to be confirmed, for example, that the shorter wavelength components of the shelf-edge gravity high are produced by features substantially shallower than the crustmantle boundary, possibly partly within the sedimentary section. One of the advantages of removing the large gravitational effects of the continental margin transition zone is that individual features in the gravity field having relatively low relief can be located in their proper positions for

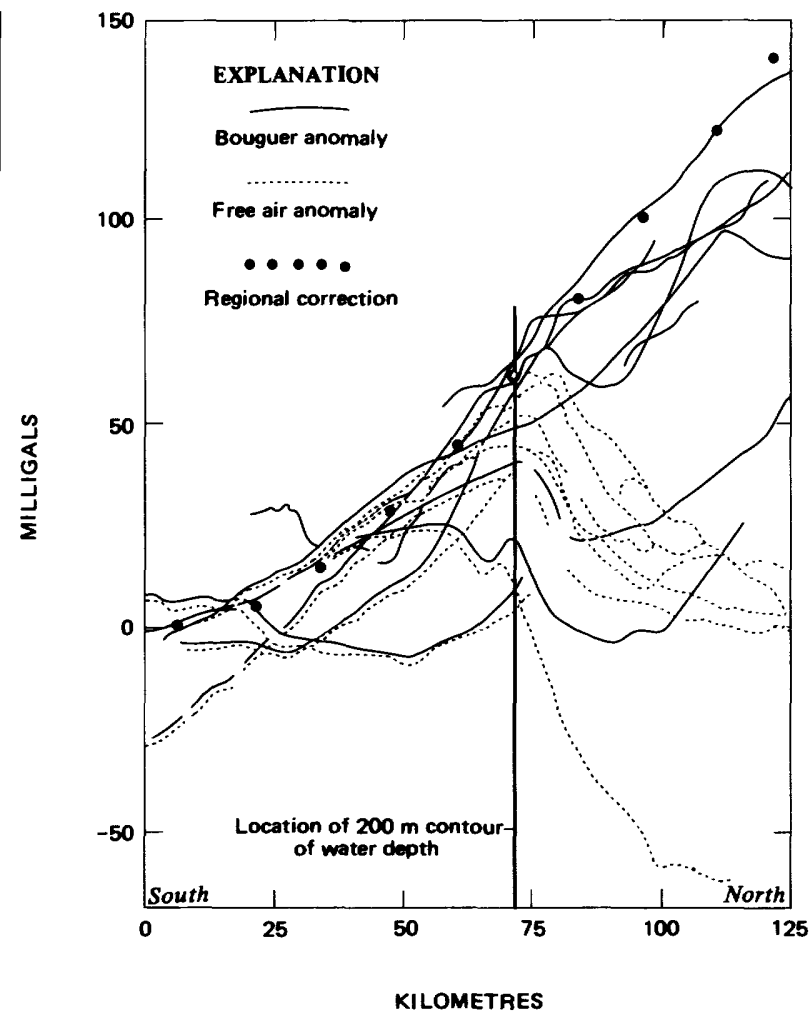

Figure 11.-Profiles for free-air and Bouguer anomalies and regional correction, Beaufort shelf.

correlation with subsurface geology. As an example, the apparent axis of a particular linear gravity feature, a WNW-striking gravity trough north of Camden Bay, is displaced several kilometres to the north of its location on the free-air anomaly map.It is concluded that this type of analysis, though subject to further modifications and refinements, will be of great value in the interpretation of other geologic and geophysical data in terms of the gravity field. Merely by more accurately locating the sources of gravity features, the technique is expected to contribute significantly to the proper choice of locations for future data collection.

\section{REFERENCES CITED}

Hanna, W. F., Ruppel, B. D., McHendrie, A. G., and Sikora, R. F., 1974, Residual magnetic anomaly and free-air gravity profiles, 1973, on continental shelf and slope between Bering Strait and Barrow, Alaska, and MacKenzie Bay, Canada: U.S. Geol. Survey open-file report 74-6, scale $1: 1,000,000$.

Hunkins, Kenneth, 1962, Submarine structure of the Arctic Ocean from earthquake surface waves: Arctic Basin Symposium Proc., Arctic Inst. North America.

1966, The Arctic continental shelf north of Alaska: Canada Geol. Survey Paper 66-15, p. 197-205. 
Wold, R. J., Woodzick, T. L., and Ostenso, N. A., 1970, Structure of the Beaufort Sea continental margin: Geophysics, v. 35, p. 849-861.

Worzel, J. L., 1968, Advances in marine geophysical research of continental margins: Canadian Jour. Earth Sci., v. 5, p. 963-983.

Environmental data collection along proposed Canadian gas pipeline along coastal route in Alaska

By J. P. Meckel

Streamflow measurements were attempted along the Arctic Gas Pipeline prime route from Prudhoe Bay to the Yukon Territory-Alaska boundary (fig. 2 (1)) November 7 to December 2 . Measurable flow exists in most major streams and in many springs near the route. In some streams (Sagavanirktok, Kavik, Jago Rivers) bodies of water were found but velocity could not be measured with instruments available. Several streams were found to be frozen to the bottom.

By the data collected earlier (April and August 1975), the flow of most springs will decline throughout the winter. The Sadlerochit Springs however, appear to flow at a steady rate.

A number of lakes along the route and a few along the coast were visited to measure ice thickness and maximum depth. Total depth (ice surface to lake bottom) ranged from 10 feet to 3.8 feet ( $3 \mathrm{~m}$ to $1.2 \mathrm{~m}$ ); with ice thickness averaging 2.7 feet $(0.8 \mathrm{~m})$.

Arctic hydrology studies

By C. E. Sloan

Analysis of LANDSAT band 7 (near infrared) imagery of the eastern Arctic Slope disclosed major icings during snow-covered periods in late winter and early spring. Remnants of the same icings could be seen in band 5 (visible spectrum) imagery during the summer when there was no snow background. This information was used to plan a water-resources reconnaissance of the eastern Arctic Slope during April 1975. Ground water, discharging as springs, flowed in open channels at the upstream edge of the large icings and could be easily measured and sampled. Measured discharge ranged from $0.85 \mathrm{ft} 3 / \mathrm{s}$ at Red Hill Spring at the west end of the Sadlerochit Mountains to 37.0 $\mathrm{ft}^{3} / \mathrm{s}$ at the Kongakut Delta icing near Demarcation Bay. Water temperature ranged from near $0^{\circ} \mathrm{C}$ at most springs to $32.8^{\circ} \mathrm{C}$ at Red Hill Spring. Except for Red Hill Spring, most of the spring water was high in dissolved oxygen, ranging from 60 to 98 percent saturation. Specific conductance of spring water was in the range 215 to 380 micromhos $/ \mathrm{cm}^{2}$, except for Red Hill Spring, where conductance was $1,000 \mathrm{microhos} / \mathrm{cm}^{2}$. The waters sampled were clear with essentially no turbidity. A followup reconnaissance in August 1975 indicated that conductance and turbidity were close to values measured in April even though streamflow regime had changed radically.

North Slope water resources studies

By Gordon L. Nelson

Inquiries by Geological Survey hydrologists indicate that industries operating on the North Slope during the winter of 1974-75 experienced critical water shortages. Pumping for construction camps and for industrial use dewatered several large pools in main channels of the Sagavanirktok and Kuparuk Rivers (fig. 2 (1)), causing serious doubt as to whether any surface-water flow exists during late winter.

North Slope petroleum program

By Robert D. Carter

Studies of the North Slope regional petroleum geology utilizing geophysical and geologic surface and subsurface methods were initiated in 1975 by Branch of Alaskan Geology and Branch of Oil and Gas Resources personnel. Important results of the studies to date are described in detail in other summary contributions in this report (Mull and others; Bird; Tailleur and others; Hunter and Fox; and Mayfield.)

Scattered seismic data including digital tapes and processed record sections were obtained and are being processed and interpreted by B. A. Kososki. Gravity stations were established in several different areas during the summer field season and these data are being reduced. In general all geophysical data were acquired in north-south transects and in proximity to other surface or subsurface information. A subsurface map folio summarizing present knowledge of the North Slope prepared by I. L. Tailleur and G. H. Pessel is being revised to reflect new well information. A preliminary study of the reservoir potential of the Lisburne Group carbonates was completed by K. J. Bird and will be published in 1976. Field studies by C. G. Mull, I. L. Tailleur, C. F. Mayfield, G. H. Pessel, R. E. Hunter, and J. E. Fox included structural, stratigraphic, and depositional environment investigations in the central and western 
Brooks Range and foothills. P. J. Swetland and G. W. Newman collected shale and oil-seep samples for hydrocarbon source potential analysis and shallow cores for paleomagnetic analysis.

New structural and stratigraphic interpretations, central and western Brooks Range and Arctic Slope

By C. G. Mull, I. L. Tailleur, C. F. Mayfield, and G. H. Pessel ${ }^{2}$

During the 1975 field season a structural transect of the central Brooks Range (fig. 12) was made from the Schwatka Mountains across the Endicott Mountains in the Killik River area. The transect provides evidence that the northern Endicott Mountains are allochthonous. North-dipping metamorphosed clastic and carbonate rocks of the Devonian and Mississippian Endicott and Lisburne Groups in the northern Schwatka Mountains are concordantly overlain by a northdipping, largely coeval, thrust sequence. This apparently allochthonous complex that forms most of the Endicott Mountains consists mainly of the Devonian Hunt Fork Shale and Kanayut Conglomerate, the Mississippian Kayak Shale and Lisburne Group, and the Permian Siksikpuk Formation. The interpretation of these relation is similar to an interpretation of the structural and strati-

${ }^{2}$ State of Alaska. Division of Geological and Geophysical Surveys. graphic relation in the Mount Doonerak area to the east (Brosgé and Reiser, 1971; Dutro, Brosgé, Lanphere, and Reiser, 1976). A distance of $80 \mathrm{~km}$ (50 mi) between the subthrust Lisburne in the south and the northern limit of allochthonous Lisburne outcrops in the Killik River area represents the minimum tectonic transport of the allochthon. Regional stratigraphic relations date the largescale thrust transport as Early Cretaceous. Late Cretaceous granitic intrusions and accompanying uplift in the Schwatka Mountains to the south are inferred to have caused the prevailing north dip of the allochthonous complex and probably resulted in erosion of the roots of the allochton somewhere to the south. The Laramide style of tectonic shortening and folding previously recognized in the Endicott Mountains (Tailleur and Brosgé, 1970, p. E6) probably accompanied the later uplift. The allochthonous nature of the Endicott Mountains was suspected by Tailleur, Brosgé, and Reiser (1967, p. 1159) from study of the De Long Mountains to the west. Evidence that the rocks of the northern Endicott Mountains are allochthonous and originally lay south of the subthrust rocks in the middle of the Brooks Range will result in substantial alteration of current isopach and facies maps of many of the rock units of the central Arctic Slope.

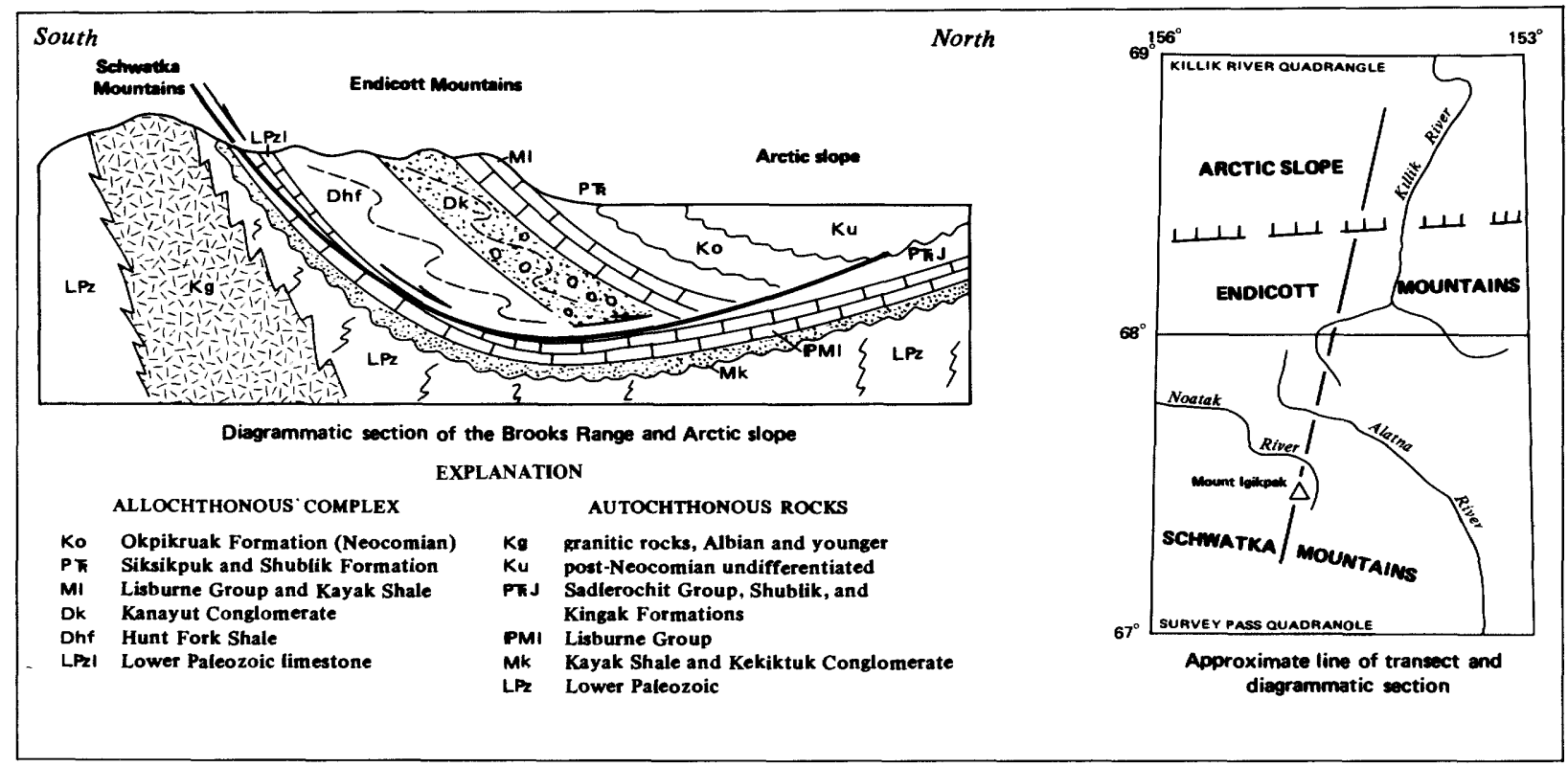

Figure 12.-Section and index map, central Brooks Range transect. 
Examination of exotic blocks of older competent rocks enclosed in Lower Cretaceous mudstone provides evidence that the chaos is depositional rather than tectonically developed. These deposits indicate a possibly discontinuous olistostrome extending from the De Long Mountains eastward into the Killik River and possibly Chandler Lake quadrangles. These olistostrome deposits (fig. 13) occur with fossiliferous earliest Cretaceous turbidites and polymict conglomerates deposited on different rock types that subsequently have been telescoped by thrust faulting. Some of the olistoliths appear to have come from rocks in structurally higher allochthons. The penecontemporaneous tectonism indicated by these deposits confirms earlier indications that large-scale tectonic shortening of the Brooks Range began in earliest Cretaceous time. In some areas, recognition of the olistostrome as a sedimentary unit rather than a complex tectonic chaos clarifies previously apparently anomalous relations and simplifies structural interpretation.

New observations reduce the problem of the palinspastic location and source of the late Paleozoic Nuka Formation (Tailleur and Brosgé, 1970, p. E2; Tailleur, Mamet, and Dutro, 1973) and for the following reasons make the Nuka an unlikely target for hydrocarbon exploration on the Arctic Slope: (1) Arkosic clasts typical of the Nuka Formation occur in earliest Cretaceous conglomerates on telescoped allochthons in the De Long Mountains. These conglomerates contain basaltic, gabbroic, and sedimentary clasts typical of allochthonous rocks extensively exposed in the Brooks Range to the south. Numerous clasts of granitic rocks no longer exposed in the Brooks Range are found in the conglomerates. (2) The Nuka Formation occurs near the top of the stacked Brooks Range allochthons. These allochthons can be demonstrated regionally to have been thrust northward relative to the Arctic Slope or, viewed from a different perspective, to have been underthrust by relative southward movement of the Arctic Slope as suggested by Tailleur and Snelson (1969). The position of the Nuka Formation near the top of the thrust sheets suggests that, relative to the Arctic Slope, it is one of the most greatly displaced rock units in the Brooks Range. (3) At Kikiktat Mountain, near the Killik River, a section of mafic rocks and chert contains thin arkosic limestone beds near the base. As at Nuka Ridge to the west, the section seems to be stacked on other

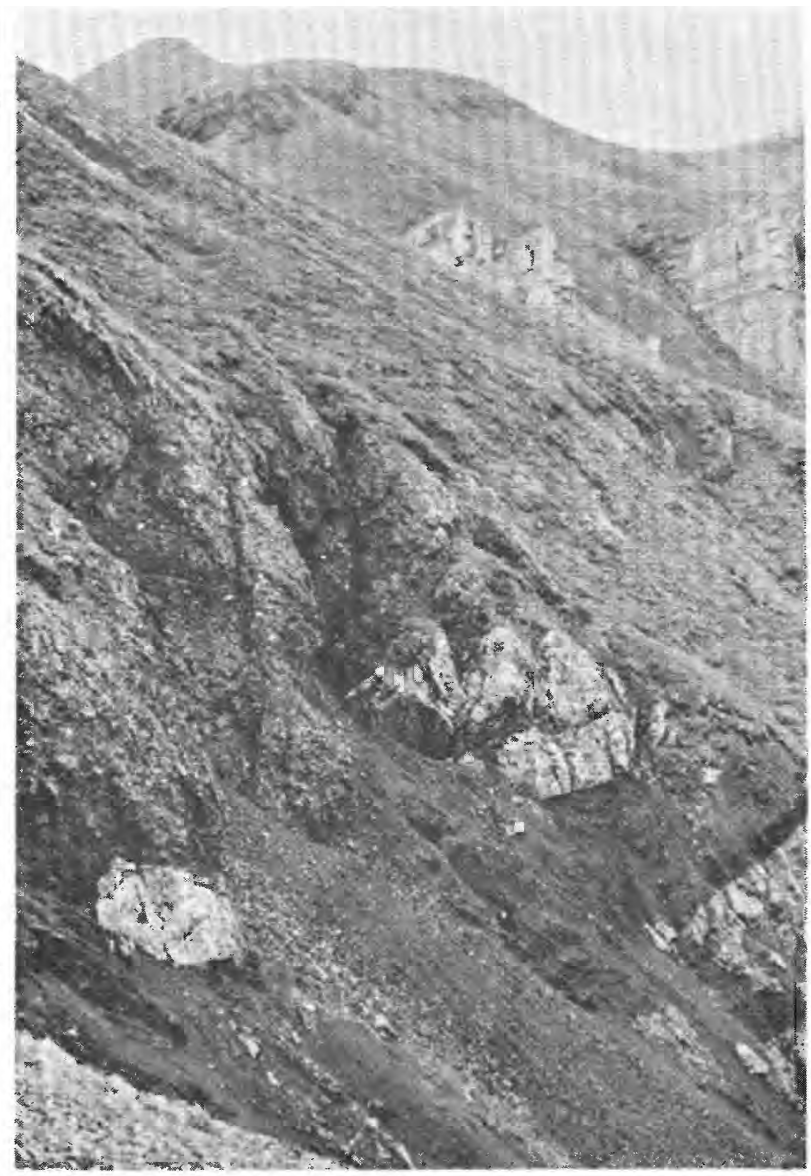

Figure 13.-A Lower Cretaceous olistostrome in the western Brooks Range. Exotic blocks of Mississippian limestone are encased in conglomeratic mudstone and overlain by massive boulder conglomerate.

allochthons. Further, regional mapping suggests that the thrust faults bounding allochthons that contain abundant mafic rocks are rooted near the southern edge of the Brooks Range. In summary, the weight of these observations suggests that the Nuka Formation was emplaced by thrusting from the south (relative to the Arctic Slope) and that it unlikely to be present as an autochthonous unit in the subsurface of the Arctic Slope.

\section{REFERENCES CITED}

Brosgé, W. P., and Reiser, H. N., 1971, Preliminary bedrock geology map of the Wiseman and eastern Survey Pass quadrangles, Alaska: U.S. Geol. Survey open-file map.

Dutro, J. T., Jr., Brosgé, W. P., Lanphere, M. A., and Reiser, H. N., 1976, Geological significance of the Doonerak structural high, central Brooks Range, Alaska: Am. Assoc. Petroleum Geologists Bull. (in press).

Tailleur, I. L., Brosgé, W. P., and Reiser, H. N., 1967, Palinspastic analysis of Devonian rocks in northwestern Alaska, in 
Oswald, D. H., ed., International Symposium on the Devonian System, Calgary, Alberta, 1967, Proceedings, Volume 2: Alberta Soc. Petroleum Geologists, p. 1345-1361.

Tailleur, I. L., and Snelson, Sigmund, 1969, Large scale thrusting in northwestern Alaska possibly related to rifting of the Arctic Ocean: Geol. Soc. America Spec. Paper 121, p. 569.

Tailleur, I. L., Mamet, B. L., and Dutro, J. T., Jr., 1973, Revised age and structural interpretation of Nuka Formation at Nuka Ridge, northwestern Alaska: Am. Assoc. Petroleum Geologists Bull., v. 57, p. 1348-1352.

Petroleum potential of the Lisburne Group, eastern Arctic Slope

By Kenneth J. Bird

Preliminary results from a subsurface study (fig. 3 (3)) of the Lisburne Group indicate that the Lisburne has all the geologic characteristics favorable for a primary objective for oil and gas exploration: porous reservoir rock, sealing beds, hydrocarbon source rocks, oil and gas shows (including one oil field), and a variety of structural and stratigraphic traps.

Porous dolomite, the most important reservoir rock, is widespread south and west of Prudhoe Bay. It thins northward by a combination of internal thinning and truncation at the top by the Permian unconformity. This reservoir rock is so widespread and consistent in the study area that its presence northward in the offshore and westward in Naval Petroleum Reserve No. 4 is predicted with a fairly high degree of confidence. However, the areal extent of the dolomite in these areas is unknown and it may be quite limited. Sandstone in the middle and upper Lisburne in two coastal wells suggests that perhaps larger areas of sandstone may be present offshore and may compensate for the very thin or absent dolomite reservoir. Oil shows are common in the dolomite and oil is present in the Prudhoe Bay structure beneath the Sadlerochit field.

Mudstone and shale of the Kavik Member of the Ivishak Formation is the most widespread and effective seal for the Lisburne. Lower Cretaceous shales unconformably overlying the Lisburne provide the seal northeast of Prudhoe Bay. Thin shales and impermeable limestones within the Lisburne may have sealing capabilities and may provide internal seals.

Early Cretaceous shales in contact with the Lisburne northeast of Prudhoe Bay have been interpreted by Morgridge and Smith (1972) as the source of Lisburne oil at Prudhoe Bay based on geochemical analyses and geologic relations.
Elsewhere the relation of source to reservoir is uncertain and will be critical to predicting hydrocarbon occurrence. Coal in the underlying Endicott Group is a probable source for natural gas. It is speculated that source-rock-quality shales may be present within the Lisburne south of the area of subsurface data and that these shales may be similar to those observed in outcropping thrust sequences.

The potential for structural and stratigraphic traps occurs over most of the area studied. Stratigraphic traps may result from the Permian unconformity south and west of Prudhoe Bay, the Early Cretaceous unconformity east of Prudhoe Bay, and possibly by local internal unconformities. Structural traps related to normal faulting may be present in a broad belt along the trend of the Barrow Arch and traps related to large faulted anticlines are present in the foothills of the Brooks Range. As the areas of potential structural and stratigraphic traps overlap, traps formed by combination of the two mechanisms may occur. The Prudhoe Bay field is an example of a combination trap (Morgridge and Smith, 1972).

\section{REFERENCE CITED}

Morgridge, D. L., and Smith, W. B., 1972, Geology and discovery of Prudhoe Bay field, eastern Arctic Slope, Alaska, in Stratigraphic oil and gas fields-classification, exploration methods, and case histories: Am. Assoc. Petroleum Geologists Mem. 16, p. 489-501.

Need to revise and test estimates of northern Alaska coal resources

By I. L. Tailleur and W. P. Brosgé

Current speculation on the potential contribution to the national energy flow from northern Alaska coals is based on an estimated 120 billion tons of identified coal resources (Barnes, 1967a, b) calculated in 1965 largely from the indirect evidence of cuttings and electric logs in two wells drilled for oil, and partly from outcrop data, and an equal amount yet to be discovered in known coalbearing areas (Averitt, 1973, p. 137; 1975, p. 14). Review of the basic data and increased knowledge of regional geology have shown that the estimated total resources should be several times, rather than only twice, the amount of the identified resources.

The areas for which Barnes calculated the coal within 3,000 feet of the surface and within 6 miles of outcrop- or well-control points aggregate only 7,200 of the $30,000 \mathrm{mi}^{2}$ of prospective coal lands in 
the western and central Northern Foothills and Coastal Plain physiographic subdivisions of northern Alaska. The same types of rocks extend westward under the shallow Chukchi Sea (Grantz and others, 1975) and underlie at least another $10,000 \mathrm{mi}^{2}$. Recent drilling in northeastern Alaska has penetrated near-surface coal-bearing, though younger, rocks beneath about $10,000 \mathrm{mi}^{2}$ in that region as well.

The randomness of Barnes's control points suffices for predicting gross hypothetical resources of the $23,000 \mathrm{mi}^{2}$ he did not assess. However, an average 20 -fold difference between concentrations of coal measured in outcrops and in wells makes detailed prediction uncertain. Calculated coal resources average 5 million tons $/ \mathrm{mi}^{2}$ from surface data, 17 million tons $/ \mathrm{mi}^{2}$ from surface and subsurface data together, and 100 million tons $/ \mathrm{mi}^{2}$ from subsurface data alone. With these figures, hypothetical resources would approximate 120 , 390 , or 2,300 billion tons and the speculative resources of the offshore and eastern regions would range from $50-1,000$ billion tons each. Based on a brief examination of logs of wells in the eastern region, J. E. Callahan (oral commun., 1975) suggested that the lower figure was the better estimate of the coal there. Without new information, an estimate of total undiscovered resources is at least 220 billion tons, possibly 3,300 billion tons.

The larger, extraordinary figure focuses attention on the importance of information from the subsurface-it suggests that an area about the size of New York State could contain more coal than the rest of the country put together (Averitt, 1975, p. 15) - and on the critical fact that few well data are direct. Concentrations of about 10 percent of the rock column or 340 million tons $/ \mathrm{mi}^{2}$ for the Kaolak and Meade wells, the two which are the bases of 76 of the 120 billion tons identified by Barnes, are even more impressive. They suggest that a half century's national energy supply could be recovered from a 12 -mile-wide strip along the 65 miles of coastal plain separating the two wells. Such concentrations and quantities seem incredible and they may well be excessive. The relatively low cost of a 1,500-3,000-foot hole, between the Kaolak and Meade wells, perhaps concurrently with oil exploration in Naval Petroleum Reserve No. 4, seems a modest investment compared with the value of the information that would $\mathrm{t}_{2}$ obtained. Optimistically, it would show trillion-ton total resources, enough to challenge technology to make use of this storehouse of energy as it has done successfully in the case of huge stores of oil and gas in the same remote and inhospitable physical setting. Pessimistically, the hole would about halve the identified resource and make the total resources (280 billion tons) comparable to or less than the estimated in-the-ground resources ( $\mathrm{Av}$ eritt, 1975, p. 14 and 15) of Colorado, Illinois, Montana, North Dakota, or Wyoming, where accessibility and environment seem generally less adverse. Either result would significantly alter the basis for speculating how northern Alaska coal could add to the national energy supply in the future.

\section{REFERENCES CITED}

Averitt, Paul, 1973, Coal, in Brobst, D. A., and Pratt, W. P., eds., United States mineral resources: U.S. Geol. Survey Prof. Paper 820, p. 133-142.

1975, Coal resources of the United States, January 1, 1974: U.S. Geol. Survey Bull. 1412, 130 p.

Barnes, F. F., 1967a, Coal resources of Alaska: U.S. Geol. Survey Bull. 1242-B, p. B1-B36.

1967b, Coal resources of the Cape Lisburne-Colville River region, Alaska: U.S. Geol. Survey Bull. 1242-E, p. E1-E37.

Grantz, Arthur, Holmes, M. L., and Kososki, B. A., 1975, Geologic framework of the Alaskan continental terrace in the Chukchi and Beaufort Seas, in Yorath, C. J., Parker, E. R., and Glass, D. J., eds., Canada's continental margins and offshore petroleum exploration: Canada Soc. Petroleum Geologists Mem. 4, p. 669-700.

Informal cooperation between U.S. Geological Survey and State of Alaska, Division of Geological and Geophysical Surveys, in the Brooks Range.

By I. L. Tailleur, G. H. Pessel, ${ }^{3}$ W. P. Brosgé, and C. F. Mayfield

Timely completion of projects of both the U.S. Geological Survey and the Alaska Division of Geological and Geophysical Surveys in the Brooks Range is being advanced through informal, but organized, cooperation. In 1975 such cooperation included: Pessel's participation in fieldwork conducted as part of the North Slope Petroleum program; short visits by Mayfield and E. M. MacKevett, Jr., to prospects on the south flank of the western Brooks Range along the "copper belt" being studied by M. A. Wiltse (Wiltse, 1975; Wiltse and others, 1975); a workshop on dislocated rocks, foreshortening, and geologic history of the northwestern and north-central Brooks Range foldbelt; and a workshop on framework geology, metamorphism, glaucophane rocks, isotopic dating, geophysics (Hackett, 1975), detailed structure

\footnotetext{
${ }^{3}$ Alaska Division of Geological and Geophysical Surveys.
} 
(Gilbert and others, 1975), and ore deposits of the southwestern Brooks Range.

The Alaska Division of Geological and Geophysical Surveys has made substantial amounts of geochemical and geophysical data available to the public. Preliminary comparisons of analyses of more than 900 geochemical samples (mainly of stream sediments) collected in 1971-72 from the southwestern and south-central Survey Pass quadrangle (Garland and others, 1975a-g) with draft geologic maps show: (1) correlation of copper and other (locally including antimony, molybdenum, barite, tin, or tungsten) anomalies with the Picnic Creek copper prospect (now undergoing intense private exploration), with a galena prospect discovered in 1973 (Alaska Division of Geological and Geophysical Surveys, 1973), with the belt of metafelsic and other rocks associated with the massive sulfide deposits, and with the eastward extension of the belt beyond Walker Lake; and (2) numerous anomalies (other than copper anomalies) related to plutonic bodies and associated altered rocks across the central part of the quadrangle.

The Alaska Division of Geological and Geophysical Surveys (1975a-d) open-filed aeromagnetic maps of the eastern two-thirds of the Baird Mountains, western two-thirds of the Ambler River, and the adjoining northern part of the Selawik and Shungnak quadrangles. High, south-sloping magnetic relief occurs over the mafic and subordinate ultramafic rocks along the south edge of the mountains and bordering lowlands (Patton and Miller, 1968; Patton and others, 1968). Lower Cretaceous conglomerate with clasts of igneous rocks produces high magnetic relief over some of its outcrop area as mapped by Patton and Miller (1968) in the Waring Mountains, Selawik quadrangle, and what is probably an eastward extension under the Kobuk valley fill. A belt of moderately high magnetic relief in the southeastern Baird Mountains quadrangle follows the outcrop of low-grade, sparsely fossiliferous pelitic strata and subordinate mafic igneous bodies that trend northeastward from the Omar River. Low magnetic relief over the main mass of the Baird Mountains does not discriminate between the rock units recognized there, nor does the magnetic pattern reflect annular bands of rock units around Hub Mountain in the northeastern Baird Mountains and northwestern Ambler River quadrangles. An area of relatively high magnetic relief in the north- central Ambler River quadrangle may outline a body of mafic rocks covered by glacial deposits.

Preparation of an open-file report on analyses of more than 550 geochemical samples collected in 1974 from the eastern Baird Mountains and western Ambler River quadrangles is nearly complete. Compilation of 1:63,360- and 1:250,000-scale reconnaissance geologic mapping in the Ambler River quadrangle is nearly complete. Aeromagnetic surveying in 1975 nearly completed coverage of the Brooks Range in the Ambler River, Shungnak, Survey Pass, and Hughes quadrangles; initial printouts (S. W. Hackett, oral commun., 1975) show additional features correlative with surface geology.

The U.S. Bureau of Mines contributed significantly to resource knowledge of Brooks Range lands withdrawn under Section 17.d.2 of the Alaska Native Claims Settlement Act of 1971 (T. C. Mowatt, oral commun., 1975). Geological consultants under contract to the Bureau of Mines to perform mineral evaluations reported (U.S. Bureau of Mines press release, Sept. 2, 1975) impressive amounts of barite and sulfides at an occurrence, noted during 1968 Geological Survey reconnaissance mapping (Tailleur, 1970) in the western De Long Mountains. The prospect has become known as the Red Dog and lies within a chert-carbonate terrane of Mississippian and Permian-Triassic age, exhumed from beneath a folded stack of allochthonous (thrust) sheets of nearly contemporaneous rocks. The announcement stimulated late-season examinations by companies but withdrawal restrictions preclude prospecting methods that would test the promise of mineralization away from surface indications.

Until recently, the broad areas of deformed, largely unaltered sedimentary rocks that make up most of the northwestern and north-central Brooks Range were considered to have a low potential for introduced concentrations of valuable minerals because similar terranes elsewhere are uncommon hosts for epigenetic mineral deposits. The discovery of the Red Dog prospect, together with the observations noted below, indicate that the resource potential of the Brooks Range should be assessed by direct means. The following findings may indicate that mineralization took place at other localities as far east as Anaktuvuk Pass:

(1) Localities in the Red Dog area with brightly stained scars and limonite-stained drainage channels similar to those produced by 
weathering of the sulfides at the prospect.

(2) Northeastward extensions of this terrane where erosion along anticlines has breached the overlying allochthonous strata. One small valley (at approx. $68^{\circ} 29^{\prime}$ N., $161^{\circ} 44^{\prime}$ W.) noted on a helicopter flight in 1975 more than 40 miles northeast of Red Dog exhibited the same discoloration.

(3) Discovery of substantial fluorite in a thin section of fragmented chert collected in 1975 on the south flank of, but at least three allochthonous sheets higher than, the extension mentioned above.

(4) An incidental report by company geologists several years ago of a fist-sized block of fluorite in Mississippian limestone talus on Mount Bupto, north of the main Brooks Range in the Howard Pass quadrangle.

(5) Several large iron-stained zones in a belt of Kanayut Conglomerate along and north of the mountain front between the Kurupa and Anaktuvuk Rivers. Analyses of geochemical samples from two of these have not been completed.

Mobil Oil Corp. released current-direction and clast-size determinations made by T. J. Donovan (now a member of the U.S. Geological Survey) at outcrops of the Endicott Group (Devonian and Mississippian). These data made possible the preparation of a map (Donovan and Tailleur, 1975) that quantitatively corroborates an earlier qualitative and empirical assessment of the northerly provenance of these clastic-wedge deposits. Dispersal patterns suggest derivation of the Devonian Kanayut Conglomerate, the dominant clastic unit in the central and eastern Brooks Range, from a westward or northwestward-trending source area and of the Kekiktuk Conglomerate, the basal Mississippian formation that transgressed northward onto the provenance of the Kanayut, from a more restricted source near the present International Boundary. Abrupt decrease in clast size within the Kanayut probably reflects structural shortening.

\section{REFERENCES CITED}

Alaska Division of Geological and Geophysical Surveys, 1973, Lead-silver occurrence in southwestern Brooks Range: Alaska Div. Geol. Geophys. Surveys, Mines Bull., v. 22, no. 11 , p. 3-4.

-1975a, Aeromagnetic map, western two-thirds of Ambler River quadrangle, Alaska: Alaska Div. Geol. Geophys. Surveys open-file report no. 76, 3 p., map scale 1:250,000. 1975b, Aeromagnetic map, eastern two-thirds of Baird Mountains quadrangle, Alaska: Alaska Div. Geol.
Geophys. Surveys open-file report no. 77, 3 p., map scale 1:250,000.

$1975 c$, Aeromagnetic map, northeastern part of Selawik quadrangle, Alaska: Alaska Div. Geol. Geophys. Surveys open-file report no. 78, 3 p., map scale 1:250,000.

1975d, Aeromagnetic map, northwestern part of Shungnak quadrangle, Alaska: Alaska Div. Geol. Geophys. Surveys open-file report no. 79, 3 p., map scale 1:250,000.

Donovan, T. J., and Tailleur, I. L., 1975, Map showing paleocurrent and clast-size data from the Devonian-Mississippian Endicott Group, northern Alaska: U.S. Geol. Survey Misc. Geol. Field Studies Map MF-692, scale 1:1,000,000.

Garland, R. E., Eakins, G. R., and Trible, T. C., 1975a, Geochemical analysis of stream-sediment samples from part of the Survey Pass A-2 quadrangle, Alaska: Alaska Div. Geol. Geophys. Surveys open-file report no. 61, 2 p., map scale 1:63,360.

$1975 \mathrm{~b}$, Geochemical analysis of stream-sediment samples from part of the Survey Pass B-3 quadrangle, Alaska: Alaska Div. Geol. Geophys. Surveys open-file report no. 62, 2 p., map scale 1:63,360.

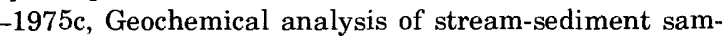
ples from part of the Survey Pass C-4 quadrangle, Alaska: Alaska Div. Geol. Geophys. Surveys open-file report no. 63, 2 p., map scale $1: 63,360$.

1975d, Geochemical analysis of stream-sediment samples from part of the Survey Pass C-5 quadrangle, Alaska: Alaska Div. Geol. Geophys. Surveys open-file report no. 64, 2 p., map scale 1:63,360.

$1975 \mathrm{e}$, Geochemical analysis of stream-sediment samples from part of the Survey Pass C-6 quadrangle, Alaska: Alaska Div. Geol. Geophys. Surveys open-file report no. 65, 2 p., map scale 1:63,360.

1975f, Geochemical analysis of rock and streamsediment samples from the Survey Pass A-3 quadrangle, Alaska: Alaska Div. Geol. Geophys. Surveys open-file report no. 66,2 p., map scale 1:63,360.

$1975 \mathrm{~g}$, Geochemical analysis of rock and streamsediment samples from the Survey Pass A-4, A-5, A-6, B-4, B-5, and B-6 quadrangles, Alaska: Alaska Div. Geol. Geophys. Surveys open-file report no. 67, 2 p., map scale $1: 63,360$.

Gilbert, W. G., Wiltse, M. A., Henning, M. W., Buza, J. W., and Kline, J. T., 1975, Structural geology of Ruby Ridge, Ambler River A-2, B-2 quadrangles, Alaska: Alaska Div. Geol. Geophys. Surveys, Mines and Geol. Bull., v. 24, no. 5, p. 2.

Hackett, S. W., 1975, Regional gravity surveys: Alaska Div. Geol. Geophys. Surveys, Mines and Geol. Bull., v. 24, p. 1-2.

Patton, W. W., Jr., and Miller, T. P., 1968, Regional geologic map of the Selawik and southeastern Baird Mountains quadrangles, Alaska: U.S. Geol. Survey Misc. Geol. Inv. Map I-530, scale 1:250,000.

Patton, W. W., Jr., Miller, T. P., and Tailleur, I. L., 1968, Regional geologic map of the Shungnak and southern part of the Ambler River quadrangles, Alaska: U.S. Geol. Survey Misc. Geol. Inv. Map I-554, scale 1:250,000.

Tailleur, I. L., 1970, Lead-zinc- and barite-bearing samples from the western Brooks Range, Alaska, with a section on Petrography and mineralogy, by G. D. Eberlein and Ray Wehr: U.S. Geol. Survey open-file report, 12 p., illus., table. 
Wiltse, M. A., 1975, Geology of the Arctic Camp Prospect, Ambler River, Alaska: Alaska Div. Geol. Geophys. Surveys open-file report no. $60,41 \mathrm{p}$.

Wiltse, M. A., Marsh, S. P., Henning, M. W., and Buza, J. W., 1975, Brooks Range copper belt, southern Ambler River and Survey Pass quadrangles: Alaska Div. Geol. Geophys. Surveys, Mines and Geol. Bull., v. 24, no. 5, p. 2-3.

Northern Alaska coal investigations, western Naval Petroleum Reserve No. 4

By James E. Callahan

Approximately $46 \mathrm{mi}^{2}$ in the Oxbow and Lookout Ridge synclinal basins (fig. 2 (6) ) were mapped geologically, with composite stratigraphic sections measured along Kokolik River across the Oxbow syncline. Nineteen coal samples were taken from outcrops on Kokolik River and Elusive Creek and along two large tributaries of Avingak Creek. Analyses of the samples by the Bureau of Mines indicate a fairly consistent rank of high volatile $B$ or $\mathrm{C}$ bituminous coal in the Oxbow-Lookout Ridge synclinal trend (the two synclines have an echelon relation separated by a small syncline). Analyses of samples taken farther north, along the south flank of the Norseman anticline, suggest a northward decrease in rank. Relation between weathered and unweathered samples from equivalent coals farther west indicate that weathering has a significant effect on coking properties in these coals. It is expected that unweathered samples from many of the oxidized beds sampled in 1975 would exhibit coking properties as well as a significant increase in rank over the surface samples.

Hydrological studies for the Alaskan Air Command

By R. J. Madison

Results of geophysical surveys made in August 1975 at Cape Lisburne (fig. 2 (7) ) indicate that the area beneath the water-collection gallery has thawed to a depth of between 40 and 50 feet. This area is suggested as the best potential for future water supply development at the Cape Lisburne facility.

Interpretation of depositional environments in the Fortress Mountain Formation, central Arctic Slope

By R. E. Hunter and J. E. Fox

Middle Cretaceous clastic rocks shed northward from the Brooks Range orogenic belt may contain a substantial amount of the hydrocarbon potential of Naval Petroleum Reserve No. 4 (NPR-4) and adjacent areas of the Arctic Slope and Chukchi Sea. Effective exploration of this potential may depend strongly on assessing environments of deposition and distribution of potential reservoir facies in terms of modern concepts of clastic sedimentation. In order to begin this type of assessment, J. E. Fox, of the Reservoir Studies Group, Branch of Oil and Gas Resources, and R. E. Hunter, of the Coastal Processes Group, Office of Marine Geology, joined I. L. Tailleur and C. G. Mull on the North Slope Petroleum field party for 2 weeks in late July 1975 . A number of exposures of the Fortress Mountain Formation and related rocks were examined, and a preliminary reconnaissance was made of representative exposures of other middle Cretaceous rocks on the central and western Arctic Slope.

The Fortress Mountain Formation of Albian age crops out extensively on Ekakevik Mountain (fig. 2 (8) ) very close to the source area, the Brooks Range orogenic belt. A detailed stratigraphic section was not measured, but three distinctly different clastic facies were recognized.

The uppermost part of the formation at Ekakevik Mountain is less than $35 \mathrm{~m}$ thick and is dominantly medium- to coarse-grained sandstone. Conglomerate beds make up less than 10 percent of the unit. The depositional environment of the uppermost part of the formation is probably shallow marine and wave-worked. This interpretation is based on the predominant low-angle, gently lenticular cross-bedding (Imbrie and Buchanan, 1965; Goldring and Bridges, 1973; Harms, 1975, p. 87-88), high degree of pebble segregation (Clifton, 1973), and presence of marine pelecypods. A fluvial origin seems unlikely because of the marine pelecypods and the absence of steeply dipping cross-bedding. A turbidite origin seems unlikely because of the absence of grading or other evidence of rapid deposition by waning currents of high density.

The middle part of the formation at Ekakevik Mountain makes up the bulk of the formation and consists largely of conglomerate; sandstone and pebbly sandstone make up less than 10 percent of the exposed rocks. The clasts of the conglomerates range from pebble to cobble size; some beds contain boulders. The beds are relatively tabular and are mostly less than $1 \mathrm{~m}$ thick. This main part of the formation was deposited by currents containing sediment moved largely by traction, probably in a braided stream or alluvial fan environment. This interpretation is based on the thinness of the conglomerate beds and the steepness of the crossbed- 
ding that occurs in many of the sandstone beds. A meandering stream origin seems unlikely because of the absence of extensive channeling or finingupwards sequences and because of the overall coarseness of the deposit. The segregation of clasts of different sizes into discrete beds is not distinct enough to suggest a wave-worked environment (Clifton, 1973). Evidence for deposition by turbidity currents or by other kinds of sediment gravity flows is lacking. None of the types of internal organization typical of "resedimented" conglomerate beds (Walker, 1975) were noted, and resedimented conglomerate beds are generally thicker than beds in this outcrop.

The lower part of the formation is exposed on the north side of Ekakevik Mountain. Only the most resistant units, forming about half of the total section, are exposed. These units are composed of conglomerate, are tabular in form, and range in thickness from about 3 to $6 \mathrm{~m}$. The conglomerate units differ from those higher in the sequence on the south side of the mountain (stratigraphic interpretation of Tailleur) by the poorer development of bedding within the lower units, by their coarser clast size, and by their poorer sorting. These conglomerates have characteristics approaching those of Walker's (1975) disorganizedbed model. The chaotic nature of disorganized-bed deposits suggests very rapid deposition from a dense sediment gravity flow, such as a debris flow. As debris flows occur on alluvial fans and on submarine slopes, the environmental implications of such deposits are not very restrictive.

In summary, the Fortress Mountain Formation at Ekakevik Mountain is interpreted as representing initial very rapid deposition of gravels in an unknown environment, followed by the deposition of braided stream and (or) alluvial fan gravels and sands, followed in turn by a transgression of the sea and deposition of nearshore marine sands. In this area the formation as a whole fines upward.

Characteristics of the sandstones in the upper part of the Fortress Mountain Formation exposed on Castle Mountain (fig. $2(10)$ ) indicate slow deposition in a dominantly fluvial or shallow marine environment, whereas on the East Fork of the Etivluk River (fig. 2 (9)), the exposed Fortress Mountain Formation consists of graded conglomerate beds deposited by turbidity currents.

The occurrence in close geographic proximity of facies of one formation ranging from undoubted turbidites to a facies that is either shallow marine or nonmarine is not surprising in an active tectonic setting. Similar juxtapositions of facies are common in Upper Cretaceous deposits along the California and Oregon coasts (see, for example, Lowe, 1972). Changes in depositional environment in such settings can come about by tectonic movements, by large-scale slumping, by rapid infilling of basins, or by rapid progradation of shelves.

\section{REFERENCES CITED}

Clifton, H. E., 1973, Pebble segregation and bed lenticularity in wave-worked versus alluvial gravel: Sedimentology, v. 20 , p. 173-187.

Goldring, Roland, and Bridges, Paul, 1973, Sublittoral sheet sandstones: Jour. Sed. Petrology, v. 43, no. 3, p. 736-747.

Harms, J. C., 1975, Stratification and sequence in prograding shoreline deposits, in Harms, and others, Depositional environments as interpreted from primary sedimentary structures and stratification sequences: S.E.P.M. Short Course No. 2, Lecture Notes, p. 81-102.

Imbrie, John, and Buchanan, Hugh, 1965, Sedimentary structures in modern carbonate sands of the Bahamas: Soc. Econ. Paleontologists Mineralogists Spec. Pub. No. 12, p. 149-172.

Lowe, D. R., 1972, Submarine canyon and slope channel sedimentation model as inferred from Upper Cretaceous deposits, western California, in Stratigraphy and sedimentology, Section 6: Internat. Geol. Cong., Proc., no. 24, p. $75-81$.

Walker, R. G., 1975, Generalized facies models for resedimented conglomerates of turbidite association: Geol. Soc. America Bull., v. 86, p. 737-748.

Metamorphism in the southwestern Brooks Range By C. F. Mayfield

Preliminary results of a continuing examination of field and petrologic data from rocks collected in the Baird Mountains and Ambler River quadrangles (fig. $3(8)$ ) indicate a belt of sedimentary, volcanic, and plutonic rocks along the south edge of the Brooks Range (Alaska Division of Geological and Geophysical Surveys, 1973, p. 6-8) as much as $40 \mathrm{~km}$ wide that has been regionally metamorphosed to the greenschist facies. Typical pelitic schists contain quartz, muscovite, albite, chlorite, \pm chloritoid, \pm calcite, \pm tourmaline, \pm magnetite, \pm carbon. Metamafic rocks most commonly contain albite, chlorite, sphene, \pm amphibole, \pm epidote, \pm quartz, \pm pyrite, or magnetite. Granitic orthogneisses contain quartz, potassium feldspar, albite, muscovite, \pm biotite, \pm zircon, \pm pyrite, or magnetite. Garnet-bearing zones occur discontinuously in the southeastern Ambler River and northeastern and central Baird Mountains 
quadrangles. Retrograded glaucophane, suggesting an early stage of high-pressure metamorphism, occurs in some metamafic and a few pelitic layers (Alaska Division of Geological and Geophysical Surveys, 1973, p. 34-36) within the garnet zone in the southeastern Ambler River quadrangle and is preserved only in metamafic bodies from the garnet zones of the central and northeastern Baird Mountains quadrangle. A gradual decline of metamorphic grade occurs both north and south of the schist belt with scattered mafic rocks showing pumpellyite grade metamorphism trailing off to a terrane composed of virtually unmetamorphosed basaltic and sedimentary rocks.

Although the petrofabrics have not been studied extensively, the belt appears to be polymetamorphic. At least two superimposed and widely divergent planes of schistosity commonly occur both in outcrop and thin section. Folding as well appears to be highly complex. Lack of comprehensive data over the wide geographic area prevents further generalizations.

Light-colored orthogneisses scattered throughout the metamorphic belt have a wide variety of compositions ranging from quartz-microclinealbite-muscovite gneisses to quartz-albitemuscovite or albite-muscovite gneisses. Alkalic metaigneous rocks occur as small stocks, plugs, and dikes exclusively in the Kallarichuk Hills of the central Baird Mountains quadrangle, and partly metamorphosed granitic rocks of the larger plutons north of the schist belt in the Ambler River country are believed to be late-stage synkinematic intrusions (90-100 m.y.) in the metamorphic terrane.

Potentially significant sulfide mineralization of high-grade copper, lead, zinc, and silver occurs within the garnet zone in the eastern Ambler River quadrangle. Proven reserves are estimated to exceed $\$ 2$ billion (Hawley, 1973, talk before Alaska Geological Society), with continuing exploration holding good prospect for finding additional reserves. Most geologists consider the sulfides to be of volcanogenic origin (Wiltse, 1975).

\section{REFERENCES CITED}

Alāska Division of Geological and Geophysical Surveys, 1973, Annual report: Alaska Div. Geol. Geophys. Surveys, 57 p.

Wiltse, M. A., 1975, Geology of the Arctic Camp prospect, Ambler River quadrangle, Alaska: Alaska Div. Geol. Geophys. Surveys open-file report 60, 41 p.
Biostratigraphy of the Permian and Lower Triassic rocks in the Philip Smith Mountains quadrangle.

By Robert L. Detterman

The Permian and Lower Triassic rocks of the Sadlerochit Group are the main reservoir beds at Prudhoe Bay. For this reason, detailed stratigraphic studies of these rocks are of significance to the country. Many exposures in the Mount Michelson and Demarcation Point quadrangles were investigated between 1969 and 1971; some of the results have been published (Detterman, 1970, 1974; Detterman and others, 1975).

In 1975 the investigations were continued in the Philip Smith Mountains quadrangle (fig. $3(6)$ ) in an attempt to see if a correlation could be made between the Sadlerochit Group and the Siksikpuk Formation (Patton, 1957) or to determine if the two sequences were entirely different and had been juxtaposed by thrust faults within the Brooks Range. Fourteen sections were measured and sampled in detail and some preliminary conclusions can be made at this time.

(1) There is no significant change in lithology between sections in adjacent thrust blocks which would indicate either that there was only minor dislocation or that the beds are remarkably uniform over a wide area.

(2) Beds within some of the thrust blocks previously mapped as Siksikpuk Formation (Lathram, 1965) contain rocks that are the time equivalent of the Siksikpuk but have few lithologic characteristics of that formation. They are perhaps best considered as a new, as yet unnamed, member of the Echooka Formation of the Sadlerochit Group.

(3) The first evidence of Permian volcanic rocks in northern Alaska was found. Two localities were investigated, one near Porcupine Lake in the Arctic quadrangle, the other near the Ivishak River in the Sagavanirktok quadrangle. Flows with some pillow structures, tuffs, and volcanic breccia were identified. These rocks locally contain an Early Permian brachiopod fauna.

Lithologically the Permian strata in the Philip Smith Mountains quadrangle can be divided into a lower and upper part that can be correlated with the Echooka and Ivishak Formations of the Sadlerochit Group (Detterman and others, 1975). The lower part is about $250-700$ feet $(76-213 \mathrm{~m})$ thick and contains massive limestone, a yellowish weathering sequence of thin calcareous siltstone 
and shale with thin limestone interbeds, and in the northeastern part of the quadrangle, a dark quartzite and quartzitic siltstone. The massive limestone with an Early Permian fauna is believed to be correlative with the Joe Creek Member of the Echooka Formation and the dark quartzite and quartzitic siltstone are considered part of the Ikiakpaurak Member. The yellow-weathering calcareous siltstone and shale with limestone interbeds is probably the time-equivalent of the Siksikpuk Formation but should be considered a new member of the Echooka Formation. Locally the siltstone and shale sequence has a slight red and green cast, but the bright variegated shale and chert of the Siksikpuk are missing. Fossils found at the base and throughout this lower part are mainly of Early Permian age and include the brachiopods Attenuatella sp., Chonetes sp., Anidanthus sp., and the gastropod Straparollus sp., according to J. T. Dutro, Jr. (oral commun.). Other forms are probably present but the collections are not completely identified at this time. The early middle Permian (Kazanian) suite of fossils characteristic of the Echooka Formation in the northeast was found overlying the Early Permian fossils in a section measured on a tributary of the Saviukviayak River.

The upper part of the sequence in the Philip Smith Mountains quadrangle is primarily dark thin-bedded siltstone and shale commonly laminated and containing concretions. These strata are believed to correlate with both the Kavik and Fire Creek Siltstone Members of the Ivishak Formation. The Ledge Sandstone is present between the two shaly units in the northeastern part of the quadrangle but pinches out southwestward. This part of the section is about $800-2,000$ feet (244 $610 \mathrm{~m}$ ) thick. The few fossils found in these rocks have not been identified but appear to be Early Triassic forms similar to those found in the type area.

The contact between the lower part of the Sadlerochit Group and the underlying Lisburne Group is disconformable. The Ivishak Formation rests disconformably to unconformably on the Echooka Formation and is overlain disconformably to unconformably by the Shublik Formation.

The Permian volcanic sequence is not clearly understood. At the locality near the Ivishak River a section of thin, silty, rusty weathering limestone and tuff apparently conformably overlies the Lisburne Group. A 4-foot $(1.22 \mathrm{~m})$ bed of limestone with brachiopods and coral overlies this unit and in turn is overlain by light- to dark-green, finegrained flows with amygdules, and pillows. The Lisburne is thrust over the Permian volcanics. The section at Porcupine Lake is allochthonous on Lower Cretaceous (Neocomian) beds. It consists mainly of about 200 feet $(61 \mathrm{~m})$ light-grayishgreen, fine- to medium-grained flows, a thin unit of volcaniclastic rock, and limestone containing volcanic debris and Permian fossils. The sequence includes some pillow structures.

\section{REFERENCES CITED}

Detterman, R. L., 1970, Sedimentary history of Sadlerochit and Shublik Formations in northeastern Alaska, in Adkison, W. L., and Brosgé, M. M., eds., Proceedings of the geologic seminar on the North Slope of Alaska: Los Angeles, Pacific Sec. Am. Assoc. Petroleum Geologists, p. 01-013.

1974, Fence diagram showing lithologic facies of the Sadlerochit Formation (Permian and Lower Triassic), northeastern Alaska: U.S. Geol. Survey Misc. Field Studies Map MF-584.

Detterman, R. L., Reiser, H. N., Brosgé, W. P., and Dutro, J. T., Jr., 1975, Post-Carboniferous stratigraphy, northeastern Alaska: U.S. Geol. Survey Prof. Paper 886, p. 46.

Lathram, E. H., 1965, Preliminary geologic map of northern Alaska: U.S. Geol. Survey open-file report, 2 sheets, scale 1:1,000,000.

Patton, W. W., Jr., 1957, A new Upper Paleozoic formation, central Brooks Range, Alaska: U.S. Geol. Survey Prof. Paper 303-B, p. B41-B43.

\section{EAST-CENTRAL ALASKA}

Geochemical reconnaissance of the Chandalar quadrangle By Sherman P. Marsh

Geochemical investigations in the Chandalar quadrangle (fig. 3 (7)) were made during the 1975 summer field season to aid in the appraisal of the resource potential of the quadrangle under the AMRAP program. Fine-grained stream-sediment and pan-concentrate samples were taken at 845 localities; bryophyte samples were collected at more than 400 of the stream sites. In addition, rocks were sampled at 89 localities. With the 365 sites sampled previously, almost 1,300 locations constitute the sample population.

Semiquantitative spectrographic analyses and atomic absorption analyses for zinc have been completed for all stream-sediment samples. Preliminary examination of these data indicate the following:

(1) A potential molybdenum resource is near the head of Geroe Creek in the north-central portion of the quadrangle. Rocks in this area, 
underlain mainly by metamorphosed Paleozoic and Mesozoic granitic rocks, are highly altered and contain abundant sulfide minerals. Streams draining this area contain from 5 to 15 parts per million (ppm) molybdenum and a series of rock samples from the main altered area contain as much as $700 \mathrm{ppm}$ molybdenum. Rock specimens from the most highly altered and sulfide-bearing area appear to be quartz-white mica-sericite schists. Most of the altered area is stained red and brown from weathering sulfides.

(2) Two zinc belts are clearly defined. One, in the northern part of the quadrangle, is associated with Devonian metasediments, mainly black slate, phyllite, and phyllitic siltstone; the other, in the south-central part of the quadrangle, is apparently associated with dark-grey to black quartz-muscovite schist, also of Devonian age. These lithologies are similar to lithologies associated with volcanogenic mineral deposits farther west in the Ambler River quadrangle. The northern belt has small areas of greenstone in its eastern half.

(3) A belt of previously known skarn deposits was extensively sampled in a cooperative program with the State of Alaska. These skarns trend northeast, form a discontinuous belt approximately $40 \mathrm{~km}$ long, and appear to be associated with a sill-like intrusive. Geochemical sampling of several of the skarns indicates high copper and molybdenum contents at the southwest end of the belt trending to high lead and silver contents at the northeast extension.

(4) Streams in the Chandalar quadrangle have a relatively low $\mathrm{pH}$, between 4.5 and 5.5. This is significant in relation to copper, as copper will remain in solution under these somewhat acid conditions, which may account for the somewhat low copper values in the streamsediment samples.

(5) Rock sampling of a small ultramafic body near Boatman Pass in the southwest corner of the quadrangle showed no platinum group metals.

\section{Geohydrology of the Fairbanks North Star Borough} By Gordon L. Nelson

Observation well data from the floodplain indicate that major recharge of the alluvial aquifers is from the Tanana River (fig. 2 (15)). Sparse data from wells in the fractured schist aquifer of the uplands indicate water level declines of $2-5$ feet
$(0.6-1.5 \mathrm{~m})$ over the summer and as much as 15 feet $(4.6 \mathrm{~m})$ during the past 3 years. Aerial photography taken during May delineates several major surface icings on small streams in the area.

Reconnaissance geologic mapping in the eastern Big Delta quadrangle

By Helen L. Foster and Florence R. Weber

Reconnaissance geologic mapping and geochemical sampling have now been completed for approximately the eastern half of the Big Delta quadrangle (fig. 3 (12)) and a reconnaissance geologic map of the Big Delta A-1 and B-1 quadrangles published (Weber and others, 1975). Analyses of the geochemical samples are not yet complete.

Several groups of metamorphic rocks have been identified and mapped (fig. 14). The largest group extends southeast into the Eagle and Tanacross quadrangles. It consists primarily of quartz-biotite gneiss and schist metamorphosed to epidoteamphibolite and amphibolite facies. Feldspathic augen gneiss is abundant, and some amphibole gneiss and schist is included. Many rocks are garnetiferous. The protoliths for this group of metamorphic rocks were dominantly sedimentary and very quartzitic. Carbonate layers are rare and fossils have not been found. These rocks may have been part of the late Precambrian Windermere Formation. The very quartzitic composition of this group of rocks is more like that of the Windermere Formation than the known Paleozoic rocks to the north or to the east in Canada.

A second major group of rocks is dominantly greenschist. The rocks are mostly quartz-mica schist with chlorite and(or) epidote imparting a green color. Metamorphic grade is greenschist facies. Coarse- to fine-grained metamorphosed grit, a common rock type throughout the unit, is used to identify the unit. Marble, quartzite, and schistose greenstone are other interlayered rock types. This metamorphic unit may be allochthonous as it seems to be bordered on the north by an irregular fault contact. The greenschist unit may extend eastward into the Eagle quadrangle and southeastward into the Yukon Territory. The age of the protoliths of the greenschist unit is unknown in the Big Delta quadrangle. In the Eagle quadrangle and in the Yukon Territory, rocks that may be correlative are probably of Paleozoic age.

At least two additional groups of greenschist facies rocks were distinguished in the northern part of the quadrangle (not differentiated in fig. 


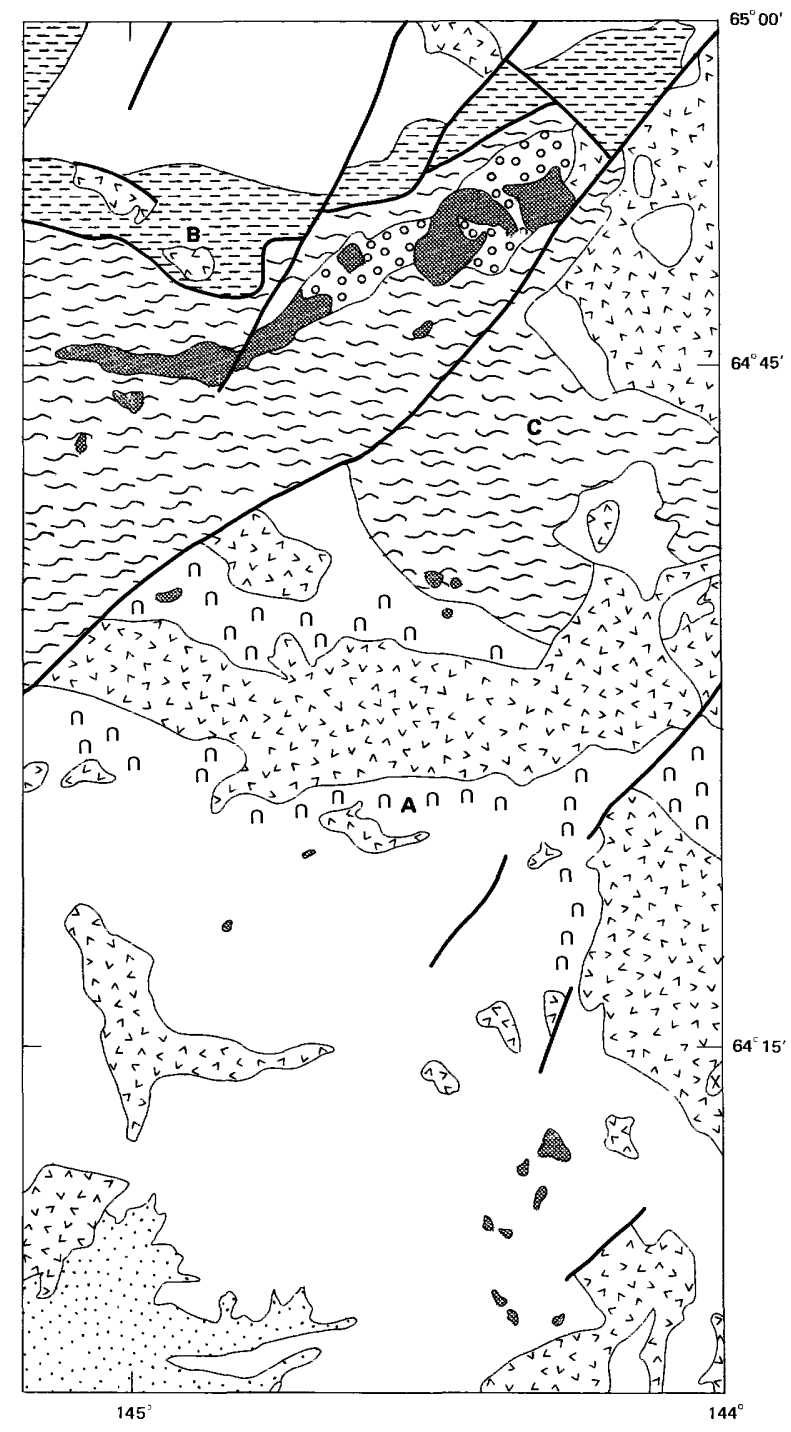

\section{EXPLANATION}

Holocene

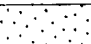

Unconsolidated deposits

Tertiary and (or) Mesozoic

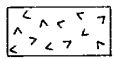

Felsic intrusive and extrusive rocks

Paleozoic and (or) Mesozoic

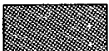

Serpentinized ultramafic rocks

Paleozoic(?)

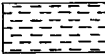

Quartzite and marble

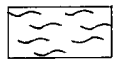

Greenschist

Paleozoic and (or) Precambrian

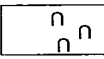

Quartz-biotite gneiss and schist, augen gneiss, and amphibolite gneiss. Symbols indicates altered gneiss

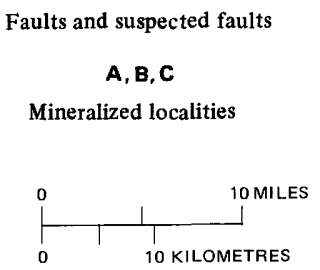

FIGURE 14.-Reconnaissance geologic map of the eastern Big Delta quadrangle.

14). They are identified by characteristic black and maroon quartzites, abundant carbonate layers, lack of grit layers, and some structural characteristics. These rocks may be allochthonous.

Serpentinized ultramafic masses are associated primarily with the greenschist unit and are tectonically emplaced. Some masses may be in thrust contact with the greenschist unit. The largest of these ultramafic bodies was examined by Allen L. Clark several years ago (oral commun., 1972; written commun., 1975). These rocks are essentially structureless masses of almost completely serpentinized peridotite. They are cut by numerous diabase dikes and bordered in places on the south and southeast sides by amphibole gneiss. On the north and northeast sides is an orange-brown quartz-carbonate zone, the most extensive and most continuous zone of quartz-carbonate rock known to be associated with any of the ultramafic bodies of the Tanana Upland. In the southeastern part of the quadrangle, several small masses of ultramafic rocks are enfolded in the amphibolite facies rocks. They are well foliated and are believed to have a different history than the large structureless masses to the north.

Examination of the Shaw Creek fault confirmed data obtained from the study of air photographs and information derived from a previous reconnaissance flight that there has been recent movement along it in the northwest corner of the Eagle 
quadrangle and in the northeast corner of the Big Delta quadrangle. A small pingo and sag ponds are present along the trace of the fault where it is active. To the southwest, the fault is less conspicuous and no indications of any recent movement were observed.

Preliminary geochemical results and mapping suggest that the eastern part of the Big Delta quadrangle is mineralized to some extent, but not enough data are yet available to determine whether or not there are promising exploration targets. A fairly extensive altered zone has been mapped around a biotite-quartz monzonite intrusion. Locally, anomalous values in copper, lead, tin, antimony, silver, and zinc were found in the rocks (A, fig. 14).

Another zone of alteration is found to the north in association with a small pluton. Anomalous values for gold, silver, tin, lead, zinc, copper, and antimony were found in some of these altered rocks (B, fig. 14).

One area (C, fig. 14) is cut by a number of small mineralized quartz veins carrying silver and as much as 2 percent copper.

\section{REFERENCE CITED}

Weber, F. R., Foster, H. L., Keith, T. E. C., and Cantelow, A. L., 1975, Reconnaissance geologic map of the Big Delta A-1 and B-1 quadrangles, Alaska: U.S. Geol. Survey Misc. Field Studies Map MF-676.

\section{WEST-CENTRAL ALASKA}

Trace-element composition of biotite from a tin-granite complex, Seward Peninsula

By Travis Hudson and R. E. Mays

One of the Late Cretaceous granite plutons of northwestern Seward Peninsula that is spatially and genetically associated with tin mineralization (a tin-granite) is the biotite granite complex exposed in the Serpentine Hot Springs (fig. 2 (14)) area. This complex is an epizonal composite stock in which several textural facies have been identified and mapped (Hudson, 1975). The textural facies were sequentially developed during fractional crystallization of the pluton and even though several mineralogic and chemical variations are related to the facies sequence, one distinctive general characteristic of the complex is the average trace-element composition of biotite.

The results of semiquantitative spectrographic analyses of 15 separates of unaltered primary biotite, including representative materials from each textural facies, are summarized in table 1. For purposes of comparison, this table includes the calculated averages and the ranges of traceelement concentrations reported by Lovering (1972) for biotites separated from some western United States granites and quartz monzonites. Compared with the data reported by Lovering, the biotites from the granite complex in the Serpentine Hot Springs area have a distinct traceelement composition that is characterized by two different element suites. The first suite includes those elements with high (enriched) concentrations- $\mathrm{Be}, \mathrm{Nb}, \mathrm{Pb}, \mathrm{Sn}, \mathrm{Zn}$, and $\mathrm{Li}-$ the second those with low (depleted) concentrations-Ba, Co, $\mathrm{Cr}, \mathrm{Ni}, \mathrm{Sc}, \mathrm{V}$, and Y. Zirconium appears to be part of the depleted suite but since zircon inclusions may play a role in the distribution of this element, the data in table 1 are inconclusive without additional petrographic information. The copper averages are about the same for the two different biotite groups but the range of values for the biotites from the Serpentine Hot Springs area is narrower. The degree of enrichment for some of the elements is spectacular: the lowest values for tin, zinc, and lithium in biotites from the Serpentine Hot Springs area are equal to, or greater than, the highest values for these elements in biotites studied by Lovering.

TABLE 1.-Average and range of trace-element abundances in biotites from some felsic intrusive rocks in the western United States and from the Serpentine Hot Springs area (all data in ppm)

\begin{tabular}{|c|c|c|c|c|}
\hline \multicolumn{3}{|c|}{ Western United States ${ }^{1}$} & \multicolumn{2}{|c|}{ Serpentine Hot Springs area } \\
\hline Element Average & Range & Average & Range & $\begin{array}{c}\text { Concentration } \\
\text { factor }^{2}\end{array}$ \\
\hline $\mathrm{Ba}_{---} 1,925$ & $300-5,000$ & 285 & $70-300$ & 0.148 \\
\hline $\mathrm{Be} \ldots \ldots+\ldots .5$ & $0-2$ & 2 & $0-10$ & 4 \\
\hline Co _... 50 & $20-100$ & 20 & $5-30$ & .4 \\
\hline $\mathrm{Cr}_{-\ldots--} 120$ & $7-300$ & 14 & $3-20$ & .12 \\
\hline $\mathrm{Cu} \ldots \ldots . \ldots 39$ & $5-200$ & 36 & $10-70$ & .92 \\
\hline $\mathrm{Nb} \ldots \ldots . \ldots 46$ & $0-150$ & 175 & $70-500$ & 3.8 \\
\hline $\mathrm{Ni}$ & $15-500$ & 9 & $0-15$ & .1 \\
\hline $\mathrm{Pb} \ldots \ldots$ & $0-70$ & 52 & $15-200$ & 5.2 \\
\hline $\mathrm{Sc} \ldots \ldots 170$ & $0-150$ & 17 & $15-30$ & .10 \\
\hline Sn $\ldots \ldots$ & $0-50$ & 175 & $50-500$ & 18 \\
\hline $\mathrm{Sr} \ldots \ldots 64$ & $10-300$ & 10 & $10-15$ & .16 \\
\hline$V_{-----.313}$ & $150-700$ & 71 & $0-100$ & .27 \\
\hline$Y_{\ldots} \ldots \ldots-\ldots 41$ & $0-300$ & 9 & $0-50$ & .2 \\
\hline $\mathrm{Zn} \ldots \ldots 75$ & $0-500$ & 920 & $700-1,000$ & 12 \\
\hline $\mathrm{Zr}$ & $15-500$ & 2 & $0-30$ & .01 \\
\hline $\mathrm{Li}$ & $0-300$ & 2,000 & $1,000-3,000$ & 60 \\
\hline
\end{tabular}

${ }^{1}$ Calculated from data reported by Lovering (1972) for 28 biotites separated from seven intrusive complexes of quartz monzonite and granite composition. ${ }^{2}$ Average Serpentine Hot Springs area/average western United States. 
Much work has been done to clarify the traceelement geochemistry of tin-granites and their constituent minerals; the data of table 1 help to confirm many general relations identified by other workers (for example, Bradshaw, 1967; Odikadze, 1967; Sainsbury and others, 1968; Stemprok, 1971; and Groves, 1972). But because the calculated averages in table 1 characterize the traceelement composition of the granite complex of the Serpentine Hot Springs area as a whole and the data are for a relatively large suite of elements, they provide the basis for making some interpretations concerning the origin of the tin-granite magma. In this regard, the important aspect of the trace-element data is the nature of the enriched and depleted element suites. The enriched suite, for the most part volatiles, are those elements that can be considered fugitive; they are not readily incorporated in mineral structures during magmatic crystallization. The depleted suite, on the other hand, includes those elements that readily enter mineral structures, in particular mafic mineral structures, during magmatic crystallization. The fact that the granite complex is intrinsically rich in fugitive elements and depleted in the other element suite indicates that it was originally emplaced as a highly fractionated residual magma developed by fractional crystallization of a larger batholith. After emplacement of this "first-order" residual magma, it underwent its own episode of fractional crystallization and generated "secondorder" residual melts, a separated aqueous phase, and tin mineralization (Hudson, 1975, and unpublished data). With respect to tin-granites in general, the proposed first (batholithic) fractionation stage in the evolution of tin-granite magmas is distinctly separate from the final fractionation stage that develops composite plutons such as that of the Serpentine Hot Springs area and leads directly to tin mineralization. This complex, twocycle magma generation-fractionation process, is a feasible origin for the tin mineralized areas of the Seward Peninsula and may help explain critical regional relations in other parts of the world where tin mineralization is associated with felsic magmatic processes.

\section{REFERENCES CITED}

Bradshaw, P. M. D., 1967, Distribution of selected elements in feldspar, biotite, and muscovite from British granites in relation to mineralization: Inst. Mining and Metallurgy Trans., v. 76B, p. 137-148.
Groves, D. I., 1972, The geochemical evolution of tin-bearing granites in the Blue Tier Batholith, Tasmania: Econ. Geology, v. 67 , p. $445-457$.

Hudson, Travis, 1975, The granite complex of the Serpentine Hot Springs area, Seward Peninsula, Alaska: Geol. Soc. America Abs. with Programs, v. 7, no. 3, p. 327-328.

Lovering, T. G., 1972, Distribution of minor elements in biotite samples from felsic intrusive rocks as a tool for correlation: U.S. Geol. Survey Bull. 1314-D, 29 p.

Odikadze, G. L., 1967, Distribution of tantalum, niobium, tin, and fluorine in micas from granitoids of the greater Caucausus and the Dzirula Crystalline Massif: Geochem. Internat., v. 4, p. 754-763.

Sainsbury, C. L., Hamilton, J. C., and Huffman, Claude, Jr., 1968, Geochemical cycle of selected trace elements in the tin-tungsten-beryllium district, western Seward Peninsula, Alaska-A reconnaissance study: U.S. Geol. Survey Bull. 1242-F, 42 p.

Stemprok, Miròslav, 1971, Petrochemical features of tinbearing granties in the Krusneé Hory Mountains, Czechoslovakia: Japan Soc. Mining Geologists, Spec. Issue 2, p. 112-118.

Revised interpretation of regional geological controls of mineralization in southwest Seward Peninsula, west-central Alaska

By C. L. Hummel

Southwest Seward Peninsula (fig. 3 (9)) has yielded three-fourths of the placer gold produced from the peninsula and contains most of the known lodes from which it was derived (Hummel, 1975). The distribution of nearly all of the primary and secondary mineral deposits in the region can now be correlated with major structures; this provides the basis for reinterpretation of the regional geological controls of the primary mineralization and reevaluation of the potential for both types of deposits in it.

Elements of nearly all of the major aspects of the geology of Seward Peninsula occur in the southwest part, and those most closely associated with the gold-bearing deposits are best represented and exposed there. Current investigations comprise topical studies throughout the region and compilation of the bedrock geology of a large part of it. The results of the work which are most concerned with regional geologic controls of the primary mineralization are summarized below and depicted in figure 15.

Nearly all of the bedrock of southwest Seward Peninsula is composed of regionally metamorphosed rocks which can be readily divided into lower and higher grade terranes. The lower grade rocks reflect both older and younger structures, whereas the higher grade rocks reflect only the younger structures. Most of both the higher and 


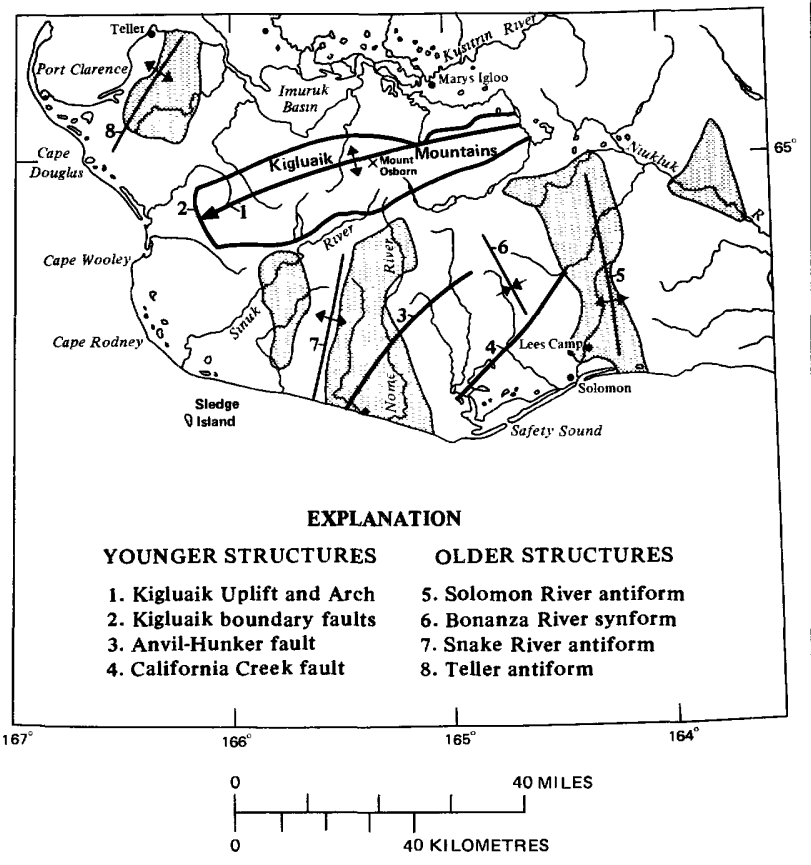

FIGURE 15.-Major structures and mineralized areas (stippled) in southwest Seward Peninsula.

lower grade metamorphites are metasediments. Those of higher grade include orthogneiss bodies from which whole-rock $\mathrm{Rb}-\mathrm{Sr}$ ages of $750 \mathrm{~m}$.y. have been obtained (Sainsbury, 1975, p. 16-17) and are probably the oldest rocks on Seward Peninsula. On the basis of gross composition, physical character, and regular metamorphic transition, they can be correlated with a thick suite of metasedimentary schist that constitutes the basal portion of the lower grade sequence. These basal rocks are overlain by thick sections of schist and marble that differ markedly from them in bulk composition and, in addition, contain abundant metamafic bodies. Like their higher grade counterparts, the basal metasediments are inferred to be among the oldest of the peninsula. The ages of the overlying metalayered rocks and their included greenstone masses have not been determined; however, some, perhaps much, of the metacarbonate may be of Paleozoic age (Sainsbury, 1975, p. 20).

On the basis of the distribution, configuration, and attitude of the basal and overlying rocks making up the lower grade metamorphites, deformed remnants of four northward-trending major folds have been delineated in southwest Seward Peninsula. Of particular importance for this purpose are three northward-trending belts of basal rocks; in the absence of adequate information concerning the true stratigraphic relation of these and the overlying rocks, the folds have been designated antiforms with axes near Teller and along the Snake and Solomon Rivers, respectively near Nome and Solomon (fig. 15). For the same reason, the fold between the last two antiforms has been named the Bonanza River synform.

A variety of evidence indicates that the contact between the basal, lower grade metamorphites and those overlying them is a major zone of movement, probably the principal and most widespread of numerous thrust faults in the lower grade terrane. From the same evidence, it is clear that this thrust fault, together with others in the rocks above and below it has been folded and regionally metamorphosed along with, and to the same degree, as the lower grade rocks in which it lies. The basic geologic framework of the lower grade bedrock of southwest Seward Peninsula thus consists of thick sequences of basal and overlying, mainly metalayered rocks, and more or less extensive thrust sheets of them, all of which have been folded and regionally metamorphosed along northward trends. The only indication of an age for the deformation that produced these older structures is a date of 100 m.y. obtained from K-Ar determinations on biotite (Sainsbury, 1975, p. 6-7). This probably represents only a phase of a long-lived sequence of events.

The older structures of southwest Seward Peninsula were subsequently strongly deformed and, in part, destroyed by later tectonic activity that produced the youngest geologic features in the region. The dominant of these is the eastwardtrending welt marked by the Kigluaik and Bendeleben mountain ranges, especially the normalfault-bounded Kigluaik Uplift, which constitutes the most recent tectonic feature in the region. Subordinate structures of the uplift include the eastward-trending Kigluaik Arch in it and the belt of lower grade metamorphites along its southern margin (Hummel, 1960, p. B33-B35) that constitutes the most strongly deformed portion of the northward-trending fold relicts south of the uplift. From the size and breadth of the older fold remnants, it is safe to assume that they once extended northward entirely across central Seward Peninsula and that their medial portions were uplifted and destroyed over the eastward-trending Kigluaik-Bendeleben welt. The duration of the de- 
formation that produced the younger structures is not known; all that can be said with certainty is that Pleistocene glacial deposits have been cut by the north boundary fault of the Kigluaik Uplift, and so manifests it as still active.

The older folds and thrust sheets are also cut and deformed by another system of younger structures, major northeast-striking and subordinate northwest-striking transcurrent faults and fractures. The Anvil-Hunker fault and California Creek en echelon faults are the principal features of the system (fig. 15). On the basis of similarity of trend and regional proximity, the system is thought to be related to the Kaltag Fault; assuming this relation, the age of the deformation that produced them has been dated as Late Cretaceous to Tertiary (Patton and Hoare, 1968, p. D152 D153.

The occurrence of gold-bearing placers in southwest Seward Peninsula is sporadic; their areal association with certain types of rocks was established in an empirical fashion during the first geological investigations there (Collier and others, 1908 , p. 113), and confirmed by the results of the recent mineral survey of the region by Sainsbury $(1975$, p. 68). Both the earlier and the later workers inferred possible syngenetic and epigenetic origins for the deposits from which the gold was derived, a syngenetic origin from the rocks with which the deposits were associated and an epigenetic origin through their localization along contacts between rock units. The same general relations have been reconfirmed during the current investigations and several additional factors can now be integrated with them: (1) lodes and altered rocks of two ages in the region, (2) the association of these and the gold placers with rocks now known to make up the basal part of the lower grade metamorphites, and (3) the distribution of most of both the primary and secondary mineral deposits, and the basal rocks along the axes of major antiforms. Additional information indicates that the preferential regional distribution of all of the mineral deposits results from the combined effects of several primary and many of the secondary factors: (1) many of the known lodes occur along the principal, folded thrust zone between the basal and overlying lower grade rocks and were regionally metamorphosed with them; (2) nearly all of the remaining lodes occur in and along the northeast-striking transcurrent faults or with the subordinate northwest-striking faults and frac- tures related to them; (3) later tectonic activity destroyed parts of the older folds, thrusts, and mineral deposits over the Kigluaik Uplift; (4) older lodes were first exposed along antiforms and gold from them was reworked in trunk drainage systems with northward trends inherited from them; (5) most gold placers first formed in these drainages were destroyed by glaciation and those formed since are the result of glacial, alluvial, and marine processes; and (6) the richest placers represent the combined effects of both primary and secondary geologic controls, the most productive having been those at Nome where gold derived from both bedrock sources was reworked from glacial and alluvial deposits into beach placers. The Snake River antiform and Anvil-Hunker fault constitute the maximum regional controls of lode mineralization, in conjunction with the best combination of secondary processes. In marked contrast, along the portion of this fault away from the antiform and along the California Creek faults, the gold placers are derived from deposits formed only during the later mineralization, and at most places these are too lean to be mined.

\section{REFERENCES CITED}

Collier, A. J., Hess, F. L., Smith, P. S., and Brooks, A. H., 1908, The gold placers of parts of Seward Peninsula, Alaska, including the Nome, Council, Kougarok, Port Clarence, and Goodhope precincts: U.S. Geol. Survey Bull. 328, 343 p.

Hummel, C. L., 1960, Structural geology and structural control of mineral deposits near Nome, Alaska in Geological Survey research 1960: U.S. Geol. Survey Prof. Paper 400-B, p. B33-B35.

1975, Mineral deposits and occurrences, and associated altered rocks in southwest Seward Peninsula, west-central Alaska: U.S. Geol. Survey open-file map 75-2.

Patton, W. W., Jr., and Hoare, J. M., 1968, The Kaltag Fault, west-central Alaska in Geological Survey research 1968: U.S. Geol. Survey Prof. Paper 600-D, p. D147-D153.

Sainsbury, C. L., 1975, Geology, ore deposits, and mineral potential of the Seward Peninsula, Alaska: U.S. Bur. Mines open-file report, 73-75, $108 \mathrm{p}$.

Uranium and thorium content of radioactive phases of the Zane Hills pluton

By Mortimer H. Staatz and Thomas P. Miller

The Zane Hills pluton (fig. 2 (12)) underlies a mountainous area of about $460 \mathrm{~km}^{2}$ in westcentral Alaska. The pluton is composed chiefly of granodiorite and quartz monzonite; monzonite and syenite occur as border phases along the southern and southeastern contacts. Earlier reconnaissance mapping and sampling had indicated that these 
border phases are much more radioactive than other parts of the pluton (Miller, 1970; Miller and Ferrians, 1968). Samples collected during this earlier work and during a brief visit in 1974 have been analyzed for their uranium and thorium content by gamma-ray spectrometry methods. The results presented here confirm the high uranium and thorium content of these border phases and suggest a favorable area for exploration. It should be emphasized that the distribution of uranium and thorium is erratic in these rocks and that detailed studies of the area have not been made.

The hornblende-biotite granodiorite that forms most of the pluton is a medium-grained equigranular rock. The hornblende-pyroxene monzonite and syenite of the border phases are generally coarsegrained rocks with a characteristic porphyritic to gneissic texture. The country rock is Lower Cretaceous andesitic flows and tuffs and the pluton has been assigned a Late Cretaceous age based on a K-Ar age determination of $80 \mathrm{~m} . \mathrm{y}$. (Patton and Miller, 1966). Contacts between the border phase rocks and the granodiorite that forms most of the pluton appear to be abrupt. Contacts between the border phase monzonite and syenite and the andesitic country rock, however, are somewhat less sharp and some K-metasomatism appears to have taken place in the andesite. Both the granodiorite and the border phase units are cut by alaskite and aplite dikes. Known mineralization in the area includes copper and molybdenum (Miller and Fer- rians, 1968) and a placer gold mine is operated in the lowlands east of the southeastern border phase.

The southeastern radioactive phase underlies an area of about $13 \mathrm{~km}^{2}$. Eleven samples collected from this area yielded from 11 to $129.5 \mathrm{ppm}$ uranium and 46 to $269 \mathrm{ppm}$ thorium with the highest uranium values found in an aplitic dike (table 2).

Allanite, the most abundant uranium and thorium mineral, was found in all but one sample. Less common uranium and thorium minerals include small amounts of black uranothorianite cubes, bright orange thorite, and dark brown octahedra of betafite. In addition, uranium and thorium are found in the ubiquitous sphene and zircon. The thorium content of two samples of sphene from this unit was 760 and $8,900 \mathrm{ppm}$ and of one zircon, $5,200 \mathrm{ppm}$. Other accessory minerals found in at least some of the samples include pyrite, geothite, lepidocrocite, chlorite, garnet, and molybdenite.

Samples from the southern radioactive phase, which underlies an area of about $25 \mathrm{~km}^{2}$ and includes hybrid diorite as well as monzonite and syenite, contained 14.5 to 33 ppm uranium and 75 to $135 \mathrm{ppm}$ thorium. All of these samples contained moderate amounts of allanite; other uranium and thorium-bearing minerals included sphene and zircon.

These values are high relative to the $7 \mathrm{ppm}$

TABLE 2.-Uranium, thorium and potassium content of selected grab samples from the radioactive phases of the Zane Hills pluton

[Analyses by Carl M. Bunker Precision of RaeU and Th analyses is 0.05 ppm plus 2 percent of stated value Precision of $K$ analyses is 0.03 percent plus 1 percent of stated value]

\begin{tabular}{|c|c|c|c|}
\hline RaeU (ppm) & Th(ppm) & K(percent) & Description \\
\hline \multicolumn{4}{|c|}{ Southeastern phase } \\
\hline $\mathrm{A}-1-74 \ldots 23.12$ & 117.3 & 6.11 & Fine-grained gneissic monzonite \\
\hline $\mathrm{A}-2-74$ & 188.8 & 4.40 & Aplitic dike \\
\hline A-3-74 & 81.94 & 6.43 & Medium-grained gneissic monzonite \\
\hline A-4-74 & 83.23 & 5.41 & Medium-grained gneissic monzonite \\
\hline $\mathrm{A}-5-74$ & 100.6 & 7.83 & Coarse-grained gneissic monzonite \\
\hline A-8-74 & 179.8 & 4.96 & Medium-grained gneissic monzonite \\
\hline $67 \mathrm{AMm} 150$ & 46.10 & 5.67 & Coarse-grained gneissic monzonite \\
\hline $67 \mathrm{AMm} 150$ & 268.85 & 5.94 & Fine-grained gneissic monzonite \\
\hline $67 \mathrm{AMm} 150$ & 69.93 & 4.91 & Coarse-grained gneissic monzonite \\
\hline $67 \mathrm{AMm} 151$ & 106.82 & 5.14 & Coarse-grained gneissic monzonite \\
\hline 67AMm 151 & 167.86 & 5.51 & Fine-grained gneissic monzonite \\
\hline \multicolumn{4}{|c|}{ Southern phase } \\
\hline $67 \mathrm{AMm} 246$ & 117.61 & 4.86 & Dioritic gneiss \\
\hline $67 \mathrm{AMm} 256$ & 75.17 & 4.01 & Medium-grained, porphyritic gneissic monzonite \\
\hline $67 \mathrm{AMm} 259 \ldots$ & 135.0 & 4.65 & Gneissic monzonite \\
\hline
\end{tabular}


uranium and $25.6 \mathrm{ppm}$ thorium reported (Miller and Bunker, 1975) for a sample from the granodiorite that forms the major part of the Zane Hills pluton.

\section{REFERENCES CITED}

Miller, T. P., 1970, Petrology of the plutonic rocks of westcentral Alaska: U.S. Geol. Survey open-file report, 132 p.

Miller, T. P., and Bunker, C. M., 1975, U, Th, and K analyses of selected plutonic rocks from west-central Alaska: U.S. Geol. Survey open-file report 75-217, 5 p.

Miller, T. P., and Ferrians, O. J., Jr., 1968, Suggested areas for prospecting in the central Koyukuk River region, Alaska: U.S. Geol. Survey Circ. 570, 12 p.

Patton, W. W., Jr., and Miller, T. P., 1966, Regional geologic map of the Hughes quadrangle, Alaska: U.S. Geol. Survey Misc. Geol. Inv. Map I-459, scale 1:250,000.

Progress report on new geologic mapping in the Ruby quadrangle

By Robert M. Chapman

Reconnaissance geologic mapping of the Ruby quadrangle (fig. 3 (10)) was begun in the area south of the Yukon River by R. M. Chapman and W. W. Patton, Jr., in 1975 to augment original mapping by J. B. Mertie, Jr., and G. L. Harrington (1924), and H. M. Eakin $(1914,1918)$, and the recompiled map, extended by photointerpretation, of J. T. Cass (1959). Most of the unmapped areas and many areas previously mapped by widely spaced foot traverses were examined briefly (14 days) to establish a base for extending recent mapping in adjacent quadrangles and to expand coverage of the Ruby Geanticline. Bedrock and unconsolidated deposits are concealed by a thick vegetation cover over large areas; considerable work still remains to be done on available exposures.

The individual and relative ages of most of the 12 generalized mapping units (fig. 16) are tentative and largely inferred from lithologic correlations with similar units in the surrounding quadrangles. The only direct age evidence is from two meager fossil collections described by Mertie and Harrington (1924, p. 21-24).

Unit OCas, exposed on one isolated hill, includes maroon and green, banded and mottled argillite and slate with minor amounts of chert, quartzitic sandstone, and basalt which are similar to the Nilkoka Group section. The probable age is Ordovician or Cambrian, possibly Precambrian. Unit Oc, a medium- to dark-gray chert with some thin shale beds, is provisionally assigned an Ordovician age because of its similarity to known or prob-

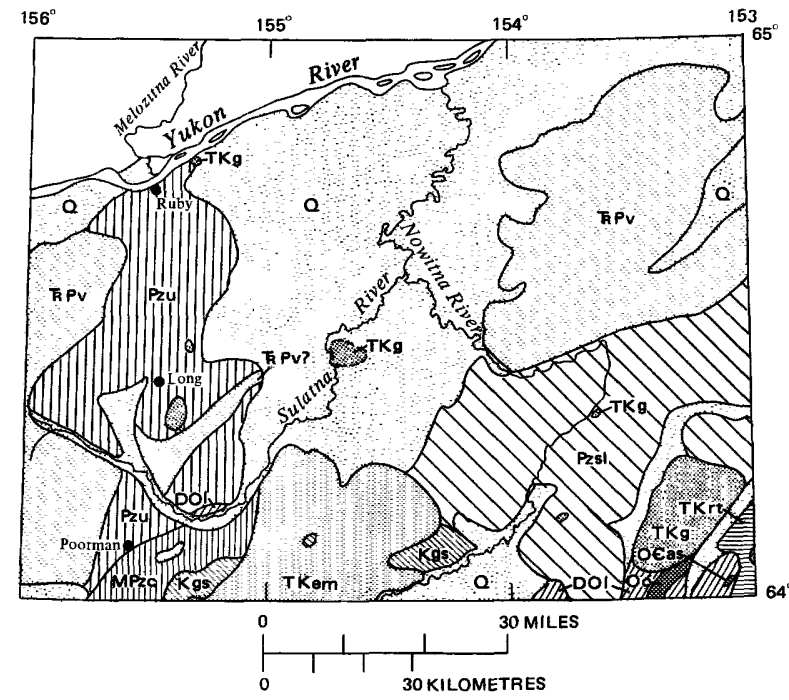

FIGURE 16.-Geologic sketch map of the Ruby quadrangle. Map units are described in text.

able Ordovician chert units in the Kantishna River, Tanana, and Livengood quadrangles. Unit DOl, closely associated with unit Oc, is mediumgray limestone and some dolomite, which locally are slightly foliated but generally are little metamorphosed. The unit is believed to be mainly of Ordovician age, but may include some Devonian and Silurian rocks; more work is needed to establish correlations with similar carbonate rocks in the Medfra and Kantishna River quadrangles.

Unit Pzsl, coestensive with unit Pzsl of the Kantishna River quadrangle (Chapman and others, 1975), includes schist, phyllite, limestone, greenstone and greenschist, and some very fine grained quartzite. These rocks are more highly metamorphosed than those in unit DOl, and presumably are of early Paleozoic (pre-Middle Devonian) and, in part, possibly Precambrian ages.

The greatly deformed, banded chert and argillite, unit MPzc, in the Poorman area was tentatively assigned a Mesozoic(?) age by Mertie and Harrington (1924, p. 22-24). Pending additional work, a correlation with unit $\mathbf{R} \mathrm{Pv}$ is suggested, but conceivably these rocks could be correlative with unit Oc.

Unit Pzu includes a structurally complex, undifferentiated assemblage of schists, greenstone, limestone, phyllite, slate, quartzite, and chert. The stratigraphic relations and ages are uncertain, mainly owing to structural complexity and discontinuous exposures. Devonian limestone, identified by one meager fossil collection (Mertie and Har- 
rington, 1924, p. 21) and possibly some Permian and Triassic rocks (unit $\mathbf{R} \mathrm{Pv}$ ), are included, but most of the rocks probably are of early Paleozoic (pre-Devonian) and possibly in part Precambrian, in part correlative with rocks in unit Pzsl.

Large areas in the western and northeastern parts of the quadrangle are underlain by basalt, diabasic rocks, chert, shale, and tuffaceous rocks of unit $\mathbf{R}$ Pv. This assemblage is typical of the Rampart Group and associated mafic rocks in the Tanana (Chapman and others, 1975) and Nulato quadrangles. The belt of these rocks north and east of the Nowitna River was first identified in 1975. Within this belt, phyllitic schists, apparently underlying and older than unit $\mathbf{R} \mathrm{Pv}$ rocks, occur in small isolated outcrops.

Unmetamorphosed graywacke, shale, siltstone, grit, and small-pebble conglomerate, unit Kgs, were discovered in 1975 at several sites west of the upper Nowitna River. This unit was mapped in part and identified as Cretaceous by Mertie (1937) and Cass (1959), and one poorly preserved ammonite imprint, possibly a Cretaceous or Jurassic type, was found (Mertie and Harrington, 1924, p. 24). These rocks resemble Cretaceous rocks in adjacent areas, but some poorly indurated, tuffaceous(?) clastic rocks included here possibly could be Tertiary. Coal, reportedly found beneath muck and gravel in prospect shafts near Poorman and Long, may belong in this unit.

The intrusive granitic rocks, unit $\mathrm{TKg}$, range from granite to diorite and are assumed to be Tertiary and/(or) Cretaceous in age. Three granitic bodies were discovered in 1975: the large pluton in the southeast corner of the quadrangle, a small stock just east of the Nowitna River, and one of unknown size $10 \mathrm{~km}$ upriver from Ruby. The boundaries of the pluton on the Sulatna River are uncertain as they are interpreted from one riverbluff outcrop, the only rock visible.

Unit TKrt includes light-colored rhyolitic volcanic rocks, some andesite, and tuff. These rocks cap the hills and extend $16-32 \mathrm{~km}$ northward and southward into the adjoining quadrangles. A Tertiary (in part Cretaceous?) age is inferred because of the lack of deformation and the close association with the granitic rocks. Unit TKem consists chiefly of extrusive basalt and andesite but includes some diabasic and rhyolitic rocks. Age relations and structure within the unit are poorly known, but these rocks apparently cap the hills and overlie unit Kgs and therefore probably are
Tertiary.

Alluvial, colluvial, and eolian unconsolidated deposits of Pleistocene and Holocene ages are mapped as unit Q. Additional work is needed to differentiate these deposits.

\section{REFERENCES CITED}

Cass, J. T., 1959, Reconnaissance geologic map of the Ruby quadrangle, Alaska: U.S. Geol. Survey Misc. Geol. Inv. Map I-289.

Chapman, R. M., Yeend, W. E., Brosgé, W. P., and Reiser, H. N., 1975, Preliminary geologic map of the Tanana and northeast part of the Kantishna River quadrangles, Alaska: U.S. Geol. Survey open-file map 75-337.

Chapman, R. M., Yeend, W. E., and Patton, W. W., Jr., 1975, Preliminary reconnaissance geologic map of the western half of Kantishna River quadrangle, Alaska: U.S. Geol. Survey open-file map 75-351.

Eakin, H. M., 1914, The Iditarod-Ruby region, Alaska: U.S. Geol. Survey Bull. 578, 45 p.

- 1918, The Cosna-Nowitna region, Alaska: U.S. Geol. Survey Bull. 667, 54 p.

Mertie, J. B., Jr., 1937, The Kaiyuh Hills, Alaska: U.S. Geol. Survey Bull. 868-D, p. 145-178.

Mertie, J. B., Jr., and Harrington, G. L., 1924, The RubyKuskokwim region, Alaska: U.S. Geol. Survey Bull. 754, $129 \mathrm{p}$.

Newly discovered Upper Triassic and Lower Cretaceous strata in the northern Kuskokwim Mountains

By William W. Patton, Jr.

A heretofore unreported section of Upper Triassic and Lower Cretaceous strata was discovered in the northern Kuskokwim Mountains by W. W. Patton, Jr., J. T. Dutro, Jr., and R. M. Chapman during 3 weeks' field mapping in the Medfra quadrangle (fig. 3(11). The Upper Triassic and Lower Cretaceous section is exposed in a narrow band around the eastern and northern perimeter of the Kuskokwim geosyncline. It overlies Paleozoic carbonate and clastic rocks of the Kuskokwim geosyncline. The Upper Triassic sequence is 100 $150 \mathrm{~m}$ thick and composed of calcareous sandstone, limestone, conglomerate, and chert with abundant Monotis. The Lower Cretaceous sequence conformably overlies the Upper Triassic and consists of about $100 \mathrm{~m}$ of calcareous sandstone, grit, shale, and coquinoidal limestone with Buchia.

This newly discovered Mesozoic section appears to have significant implications for the tectonic history of central Alaska. Lithologically, it has strong affinities for coeval rocks in northern Alaska but contrasts sharply with the Permian to Lower Cretaceous island arc and oceanic volcanic assemblages that lie immediately to the north in 
the Yukon-Koyukuk province (Patton, 1973). The high content of carbonate and quartz detritus and the absence of volcanogenic debris suggest that the provenance of these strata was confined to the carbonate-quartzite-pelitic schist terrane of the Ruby geanticline.

It has been suggested that the Paleozoic and Precambrian(?) terrane of the Ruby geanticline represents a sliver of the Brooks Range-Seward Peninsula continental crust that was rifted away at the end of the Paleozoic (Patton, 1970). From late Paleozoic to Early Cretaceous, the wedgeshaped Yukon-Koyukuk province, situated between the Brooks Range-Seward Peninsula and the Ruby geanticline, was a marginal sea or miniocean basin. Following this model, the nonvolcanic Upper Triassic and Lower Cretaceous section in the northern Kuskokwim Mountains may be interpreted as a clastic wedge which was deposited along the trailing edge of the rifted fragment.

\section{REFERENCES CITED}

Patton, W. W., Jr., 1970, A discussion of "Tectonic history of northern Alaska" by I. L. Tailleur and W. P. Brosgé, in Proceedings of the geological seminar on the North Slope of Alaska: Am. Assoc. Petroleum Geologists, Pacific Sec., p. E20.

1973, Reconnaissance geology of the northern YukonKoyukuk province, Alaska: U.S. Geol. Survey Prof. Paper 774-A, 17 p.

Sedimentary facies and structures of the northern Bering epicontinental shelf

By C. Hans Nelson, Robert W. Rowland and Sam W. Stoker"

Distinctive Holocene transgressive sands and posttransgressive muds with attendant physical and biological structures can be defined on the shallow $(<60 \mathrm{~m}$ ) shelf of northern Bering Sea (fig. 3 (5)). Exposed glacial moraines typically are veneered with a thin gravel lag layer deposited by the Holocene shoreline transgression. Buried thin layers of transgressive beach sand and gravel retain rare medium-scale cross and flat lamination. Where exposed, ancient submerged beach ridges contain faint rippling that probably is caused by modern current reworking. An offshore finegrained sand facies was deposited by the Holocene transgression; it makes up a thin layer over the central area and is without physical structures mainly because of ampelicid amphipod bioturbation.

Post-transgressive silty mud from the Yukon

${ }^{4}$ Institute of Marine Science, University of Alaska.
River blankets the shallow ( $\leqslant 20 \mathrm{~m}$ ) Norton Sound. In places it contains thin horizons of shells and pebbles and thin lenticular sand interbeds that exhibit cross and flat lamination and rippling. The coarse-grained interbeds are interpreted to be lag deposits of modern storm waves and associated storm surge currents that have reworked the shallow sea floor. Well-preserved physical sedimentary structures occur only near the delta fringe, where frequency of physical reworking is highest and low salinity may inhibit benthic faunal activity that usually destroys physical structures.

The predominance of bioturbation on this shelf results from: (1) surface-distributing and shallow-burrowing $(0-5 \mathrm{~cm})$ organisms such as brittle stars, crabs, snails, sand dollars, and perhaps large mammals; (2) shallow- and intermediate-burrowing $(0-10 \mathrm{~cm})$ amphipods, clams, and polychaete worms; and (3) deepburrowing ( $>10 \mathrm{~cm}$ ) clams, polychaete worms, and holothurians.

\section{SOUTHWESTERN ALASKA}

Water-resources reconnaissance of St. George Island, Pribilof Islands

By G. S. Anderson

A hydrologic reconnaissance of St. George Island (fig. 2 (37)) was made in May 1974 to determine the feasibility of locating a source of water containing less sodium chloride than the present supply. Existing wells may be either too deep relative to sea level or too close to the ocean; they may be pumping from a transition zone between the freshwater and saltwater bodies. Surface-water availability is limited. Several freshwater springs suggest the presence of ground water of good quality. The island is relatively narrow, the rate of recharge is low, and the rocks are permeable; it is therefore concluded that the freshwater lens is thin. Fresh ground water should be obtainable near the center of the island, but production wells should be designed so as to skim fresh water off the top of the salt water.

Mercury dispersal in Kuskokwim River and Bay

By C. Hans Nelson, Everett A. Jenne, Bradley R. Larsen, and Dennis H. Sorg

Analyses of mercury in suspended sediments of the Kuskokwim River and Bay system (fig. 3 (5), (26)) detected normal values of $0.1-5 \mathrm{ppm}$ in most places, and anomalies reaching more than 500 ppm near cinnabar lode deposits along the middle 
Kuskokwim River and its tributaries. As did values in bottom sediments, suspended-sediment values dropped to normal within about $20 \mathrm{~km}$ of lode sources. This again emphasizes the significant difference between naturally contaminated systems and polluted systems where anomalies may extend downstream for hundreds of kilometres.

Atomodesma in southwestern Alaska

By Joseph M. Hoare and Warren L. Coonrad

Atomodesma is an uncommon but geographically widespread Permian bivalve. It has long been recognized as a valuable Permian guide fossil in Australia, New Zealand, and elsewhere in the world but has only recently been identified in North America (Kauffman and Runnegar, 1975). During the field season of 1975 we collected Atomodesma at 25 localities in southwest Alaska in the Goodnews, Hagemeister Island, and Bethel 1:250,000 scale quadrangles. We also obtained specimens collected by William Polski of the Shell Oil Co. from a locality in the Taylor Mountains quadrangle.

The specimen suites range in size from only one or two tiny fragments to many large fragments $8-15 \mathrm{~cm}$ in size. Only two essentially complete shell molds were found. From the standpoint of shell morphology and classical paleontology, probably only two of the collections have any value, but from the standpoint of geologic mapping they are all equally valuable because they extend the known stratigraphic and geographic range of Permian strata in southwestern Alaska.

Most of the fossils were found in fetid limestones that range in thickness from a few metres to $300 \mathrm{~m}$. They were found in argillite, graywacke, and coarse conglomerate. At several localities Atomodesma are associated with other fossils (brachiopods, bryozoa, corals, and crinoid columnals) of Permian age, but at most localities other fossil forms are rare, absent, or too fragmentary to be identified. Atomodesma fragments as small as $2-3 \mathrm{~mm}$ were readily identified, with the help of a hand lens, by their rectangular shape and fibrous texture. The detrital nature of Atomodesma shell fragments makes their occurrence highly erratic. They may be concentrated in one or more horizons or thinly disseminated throughout large exposures. Whether concentrated or disseminated, it is commonly necessary to spend considerable time looking for them.
Although the aggregate thickness of fossiliferous rocks of Permian age in southwestern Alaska is relatively small, these rocks indicate the geologic age of a much thicker sequence of nonfossiliferous strata, as they are interbedded with several thousand metres of largely volcanogenic rocks consisting of pillow basalts, tuffs, siliceous argillite, and chert. These and younger rocks of Mesozoic age are isoclinally folded and cut by many low-angle thrust faults. The widespread occurrence of Atomodesma has been helpful in unraveling certain aspects of the structure and stratigraphy.

\section{REFERENCE CITED}

Kauffman, E. G., and Runnegar, Bruce, 1975, Atomodesma (Bivalvia), and Permian species of the United States: Jour. Paleontology, v. 49, no. 1, p. 23-41.

The Togiak tuya

By Warren L. Coonrad and Joseph M. Hoare

Flat-topped volcanoes formed by subglacial eruptions originally were defined as "tuyas" by W. H. Mathews (1947). During the 1975 field season, W. L. Coonrad and J. M. Hoare, who had long speculated about the origin of the isolated volcanic butte (fig. 2 (34)) in Togiak Valley, finally recognized that it was a typical tuya. The lower Togiak Valley is $25-30 \mathrm{~km}$ wide and is considered to be a graben or half-graben. The last glacial advance occurred 12,000-15,000 years ago and the valley was filled with ice to a depth of 500-650 m (1,500 $2,000 \mathrm{ft}$ ).

The tuya erupted on or near the Togiak-Tikchik fault about $3 \mathrm{~km}$ from the east valley wall. It rises

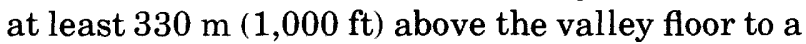
flat summit that slopes slightly southward. The ground plan is an oval about $6 \mathrm{~km}$ (3.5 miles) from north to south and $3 \mathrm{~km}$ (1.5 miles) wide. The slopes are steep to precipitious except at the south end, where they are moderate.

The north end of the tuya is a cone made up largely of fragmented yellow, brown, and black glassy foam. The foamy material is apparently mostly hydrated basaltic glass (palagonized sideromelane). It exhibits a crude bedding and crops out in the broken rim of a shallow saucershaped depression. The dip of the bedding indicates that the depression is a remnant crater in the top of the cone. To the south, the cone is overlain by flows of olivine basalt. The flows dip gently southward and extend only a short distance south of the 
tuya. The flows are fine grained, with considerable interstitial glass, and exhibit small poorly defined columns and apparently cooled and froze quickly after they were extruded.

The construction of the tuya is visualized as follows: It began with the subaqueous eruption of basalt beneath a lake that melted out of the Togiak glacier. The subaqueous eruption continued until a cone consisting largely of hydrated sideromelane breccia at least $330 \mathrm{~m}(1,000 \mathrm{ft})$ high had been built. The cone-building stage ceased when the lake drained and the eruption continued with the effusion of olivine basalt lava flows from the south side of the cone. The Togiak glacier apparently overrode the tuya after volcanic activity ceased because the tuya is littered with glacial erratics and the north side of the cone at the north end of the tuya was truncated by glacial abrasion.

The Togiak tuya is the first such feature recognized in Alaska (R. R. Coats, oral commun., 1975). There should be others on the Alaska Peninsula or in the Alaska Range.

\section{REFERENCE CITED}

Mathews, W. H., 1947, "Tuyas," flat-topped volcanoes in northern British Columbia: Am. Jour. Sci., v. 245, no. 9, p. $560-570$.

Two caldera-forming eruptions on Umnak Island, eastern Aleutian Islands

By Thomas P. Miller and Robert L. Smith

The existence of two ash-flow sheets surrounding Okmok caldera (fig. 2 (36)) on Umnak Island in the eastern Aleutians has been documented. The relation between the ash-flow sheets can best be seen on the northwest side of the island, where they are locally separated by a basalt flow 6-9 m thick. A hiatus between the extrusion of the basalt and the deposition of the upper ash-flow sheet is suggested by a well-developed erosional surface on the basalt; in places, stream channels were cut through the basalt and later filled by the younger ash flow. The occurrence of two ash-flow units indicates at least two major caldera-forming eruptions at Okmok caldera, a possibility first raised by Byers (1959), who suggested Okmok might be a double caldera.

\section{REFERENCE CITED}

Byers, F. M., Jr., 1959, Geology of Umnak and Bogoslof Islands, Aleutian Islands, Alaska: U.S. Geol. Survey Bull. 1028-L, p. 267-369.

\section{SOUTHERN ALASKA}

Hydrologic investigations related to coal resources By D. R. Scully

Beluga area (fig. 2 (23)) water-discharge, suspended-sediment, and water-quality data were collected at six stream locations in August 1975 and at eight stream locations in October 1975. Discharges were in the medium-flow range (1.3 to $\left.6.1\left[\left(\mathrm{ft}^{3} / \mathrm{s}\right) / \mathrm{mi}^{2}\right)\right]$. Specific conductance ranged from 25 to 50 siemens, $\mathrm{pH}$ from 6.9 to 7.5 , and dissolved oxygen was at or near saturation. Water was sampled at two springs in October 1975.

Peters Creek area (fig. 2 (19)) water-discharge, suspended-sediment, and water-quality data were collected at two stream locations in August and October 1975. Discharges were in the mediumflow range (2.1 to $\left.3.2\left[\left(\mathrm{ft}^{3} / \mathrm{s}\right) / \mathrm{mi}^{2}\right]\right)$. Specific conductance ranged from 45 to 55 siemens, $\mathrm{pH}$ from 6.5 to 7.7 , and dissolved oxygen was at or near saturation.

Healy area (fig. 2 (16)) water-discharge, suspended-sediment, and water-quality data were gathered at three stream locations in July 1975 and at one stream location in September 1975. Specific conductances were in the 400 to 500 siemens range, whereas $\mathrm{pH}$ ranged from 7.8 to 8.6. Waters in four wells were sampled in September 1975.

Alaska glaciology studies

By D. C. Trabant

The long-term monitoring programs at Wolverine and Gulkana Glaciers, though considerably reduced in intensity from the level of activity during the International Hydrologic Decade, continue with the gathering of continuously recorded air temperature and precipitation data and summer stream stage data from both glacier basins. Mass balance and ice motion measurements were made at three points on Wolverine Glacier (fig. 2 (31)) in February, June, August, and October of 1975. The development and implementing of a routine ice kinematics monitoring program has resulted in the first year of data being collected at Wolverine Glacier. Mass balance measurements at three points on Gulkana Glacier (fig. 2 (18)) were made in February, June, and August of 1975 . The first ice movement measurements were made during the August trip.

Aerial photography in May, the first of the season, covered the central Alaska Range. June aerial 
photography included glaciers in the central and eastern Alaska Range and the central Chugach and Wrangell Mountains. Special attention was given to Mount Wrangell (fig. 2 (27)) and its summit area to detect changes in the glaciers and glacier activity (fig. 17) that may be related to increased heat flow. August photography of the Alaska Range, Tordrillo, Wrangell (including Mount Wrangell), and Chugach Mountains was the most extensive reconnaissance of the season. Two flights in October again documented snow lines and glacier activity in the central Alaska

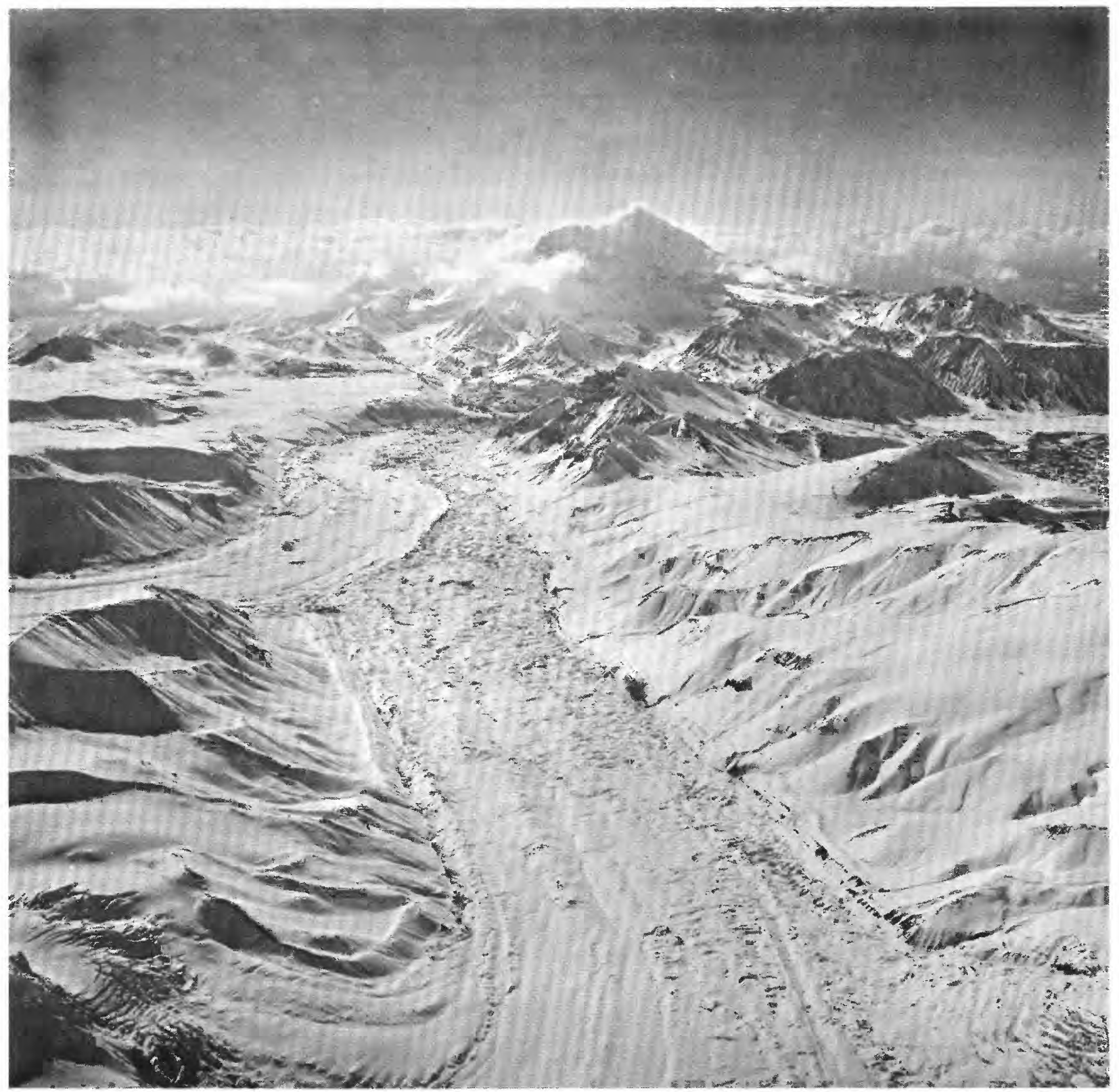

FIGURE 17.-Sanford Glacier with Mount Drum in the background, Wrangell Mountains, April 1974. The increased activity of the glaciers around Mount Wrangell is evident in the photograph. The tributary on the left is on the flanks of Mount Wrangell and is seen here pushing strongly into the main stream of the glacier that heads on Mount Sanford. (USGS photograph 74M1-75.) 
Range and Wrangell Mountains.

Increasing iceberg hazard in front of Columbia Glacier (fig. 2 (32)) was assessed in August and October during aerial photography flights. This photography will be cataloged and a listing published in Glaciological Notes, World Data Center A: Glaciology-U.S. Geological Survey, 1305 Tacoma Avenue South, Tacoma, Wash. 98402.

\section{Glaciers along TAPS route}

By D. C. Trabant

The Black Rapids Glacier (fig. 2 (17)) surge hazard to the trans-Alaska pipeline continued to be monitored. Ice balance and motion measurements were made in February and August of 1975. In August a survey net was established that will permit rapid analysis of ice kinematic data and the integration of mass balance and ice kinematic data for an analysis of the glacier's activity.

Gulkana Glacier (fig. 2 (18)) serves as the best monitor of climatically induced glacier advances in the Alaska Range. Ice mass balance was measured in February, June, and August of 1975. A survey net was established in the Gulkana basin in August and the first ice kinematic measurements have been made.

Aerial photography reconnaissance of glacier and glacier-related hazards to the pipeline were made in May, June, August, and October of 1975. The October photography shows an iceberg plume coming from Columbia Glacier (fig. 2 (32) ) that may prove a hazard to tanker traffic in and out of Port Valdez. A listing of the aerial photography will be published in Glaciological Notes, World Data Center A: Glaciology-U.S. Geological Survey, 1305 Tacoma Avenue South, Tacoma, Wash. 98402. An analysis of the glacier and glacierrelated hazards along the trans-Alaska pipeline will be completed.

Water-resources investigations of the Valdez-Delta Junction area

By C. E. Sloan

Fieldwork in the last year of this project was done along the trans-Alaska pipeline through the Alaska Range from Summit Lake to Delta Junction (fig. 2 (5)). Streamflow in this area is highly seasonal, being low in the major streams and nonexistent in the smaller streams through most of the winter. Summer flow is dominated by a breakup peak in the nonglacial streams.
Reconnaissance geology of the western Talkeetna Mountains quadrangle

By W. H. Nelson, Béla Csejtey, Jr., and R. M. Dean

By the end of the 1975 field season, reconnaissance geologic mapping was completed in most of the western half of the Talkeetna Mountains 1:250,000 quadrangle (fig. 3 (13)).

The oldest rocks in the quadrangle are a sequence of basaltic to andesitic volcanic and volcaniclastic rocks more than $5,000 \mathrm{~m}$ thick, with argillite and limestone interbeds (Csejtey, 1974). Most of these rocks are metamorphosed, commonly to greenschist facies, although locally near plutons they attain amphibolite grade. Several of the metamorphosed limestones yielded identifiable marine faunal assemblages of Early Permian age (Csejtey, 1976). The volcanogenic rocks of this Paleozoic are interpreted to be the remnants of a volcanic arc system.

Probably the next oldest rocks consist of a unit of vescicular basalt and intercalated argillite, a few hundred metres thick, in the northwest part of the quadrangle. These rocks probably correlate with the Nikolai Greenstone of eastern Alaska.

Lower Jurassic rocks constitute a thinly bedded sequence, at least a few hundred metres thick, of layered tan to black chert and tan siliceous argillite in the extreme northwest corner of the quadrangle. The age of these rocks was determined by newly found ammonite fragments (R. W. Imlay, written commun., 1975).

Rocks, determined to be Cretaceous on the basis of a single Inoceramus sp. fragment (D. L. Jones and A. T. Ovenshine, oral commun., 1974) make up a thick and monotonous sequence of black slates and graywackes in the northern half of the quadrangle.

All the Paleozoic and Mesozoic rocks are intensely deformed, and all their major units are in tectonic contact with each other.

Little altered Cenozoic volcanic rocks cap ridges and mountain tops in the central part in the quadrangle. In the western part of their extent, these volcanic rocks consist mostly of gently dipping brown andesitic flows interlayered with minor amounts of tuff. In the eastern part of their known extent, they consist of tan volcaniclastic rocks that contain lenticular brown flows; these eastern volcanic rocks have steeper, irregular attitudes, and seem to be in part at least somewhat more felsic than the volcanic rocks to the west. They contain numerous dikes that locally make up more than 
half the volume of the bedrock. The abundance of dikes, irregularity of attitudes, lenticular nature of flows, and abundance of pyroclastic material suggest deposition near the vent of a stratovolcano, whereas the gentle dipping more widespread flows to the west suggest deposition on gentler slopes on the flank of a stratovolcano or on a shield volcano that formed near the stratovolcano. The eastern and western volcanic rock types interfinger at least in part. These volcanic rocks are fresh and little deformed; most of their structure seems to be depositional. E. M. MacKevett, Jr. (oral commun., 1975) has stated that these rocks seem to be identical with the Wrangell Lava, which ranges from Miocene to Holocene in age. These volcanic rocks provide a link between the andesitic volcanos of the Aleutians and the Wrangell Mountains.

Middle Jurassic to early Tertiary plutonic rocks ranging in composition from diorite to granite occur throughout the quadrangle. The oldest plutonic rocks, tonalites and granodiorites about 165 to $145 \mathrm{~m}$.y. old, underwent strong cataclastic deformation. These old plutonic rocks include one large pluton and several smaller ones associated with intricately migmatized schists and amphibolites derived from the Paleozoic volcanics. The migmatites and associated plutonic rocks are in turn intruded by little-deformed two-mica granites between 140 and $120 \mathrm{~m} . \mathrm{y}$. old. As none of the young granites are appreciably deformed, the most intensive metamorphism, accompanied by plutonism, apparently occurred in the quadrangle during Jurassic time.

The Talkeetna Mountains quadrangle lies just south of the arcuate Denali fault system and a southwest-trending Cretaceous suture zone (Csejtey, 1976; Jones and others, 1976). Many of the structures in the quadrangle can be related to these features. Large-scale structures in the quadrangle are isoclinal folds and high- to intermediate-angle faults, probable thrusts; they all parallel the southwest-trending suture zone to the north. These structures, which determine the distribution of the major sedimentary units in the quadrangle, seem to have originally developed in the Cretaceous when an allochthonous continental block, now the terrane south of the suture zone, collided with the North American plate. The southwesterly regional structural trend of the quadrangle is thought to reflect the shape of the North American continent against which the rocks in the quadrangle have been molded.

There is a fairly sharp bend in the course of the Denali fault system just north of the mapped area. The part of the system east of this bend has been interpreted by Richter and Jones (1973) to be an active dextral strike-slip fault, caused by northwestward subduction and underthrusting by the Pacific plate since the Miocene. Mechanically, it is not possible for strike-slip movement alone to take place along a fault with nonuniform radius of curvature. Csejtey $(1974 ; 1976)$ has argued that while strike-slip movement is dominant along the eastern Denali fault, west of the sharp bend the Denali is but one strand of a not yet fully known zone of overthrusts and underthrusts. The great height of the Alaska Range northwest of the quadrangle could be the result of this thrusting. Several newly discovered steep thrusts, with apparent recent movement near the northern part of the quadrangle, may be part of the postulated thrust zone.

\section{REFERENCES CITED}

Csejtey, Béla, Jr., 1974, Reconnaissance geologic investigations in the Talkeetna Mountains, Alaska: U.S. Geol. Survey open-file report $74-147,48 \mathrm{p}$.

1976, Tectonic implications of a late Paleozoic volcanic arc in the Talkeetna Mountains, south-central Alaska: Geology, v. 4, no. 1, p. 49-52.

Jones, D. L., Pessagno, E. A., Jr., and Csejtey, Béla, Jr., 1976, Significance of the Upper Chulitna ophiolite for the late Mesozoic evolution of southern Alaska: Geol. Soc. America Abs. with Programs, v. 8, no. 3, p. 385-386.

Richter, D. H., and Jones, D. L., 1973, Structure and stratigraphy of eastern Alaska Range, Alaska: Am. Assoc. Petroleum Geologists Mem. 19, p. 408-420.

Geochemical anomalies in the Willow Creek mining district, Talkeetna Mountains

By M. L. Silberm and R. M. O'Leary

A geochemical reconnaissance was carried out for 2 weeks in the Willow Creek mining district (fig. $2(25)$ ) in the southern Talkeetna Mountains. Willow Creek was a lode-gold mining district that produced ore valued at $\$ 18$ million from quartz veins in Mesozoic granodiorite. The geology and mineral deposits were described by R. G. Ray (1954).

Several sets of quartz veins, including the gold bearing, occur in the granodiorite. Ray (1954) reported the occurrence of copper, lead, and zinc sulfides in both barren and gold-bearing veins. Northeast of the Talkeetna Mountains in the eastern Alaska Range many disseminated copperporphyry deposits occur in batholithic granitic 
rocks similar to those in the Talkeetna Mountains. Levels of erosion are deeper in those batholithic complexes than in the southern Talkeetna Mountains. The gold deposits and presence of base-metal sulfides in the veins indicate the possibility of disseminated copper at depth, with the gold occurring in a shallow, zoning relation to deeper base-metal mineralization.

To evaluate this possibility, a sampling program was started in the summer of 1975 , when 100 samples were collected from about 50 locations. Samples consisted of quartz veins, shear-zone material, and altered rocks from mines, prospects, and outcrops. Preliminary results indicate:

(1) Copper content of the samples varies from 0 to 1 percent and tends to be highest in an area of approximately $1 \mathrm{mi}^{2}$ in the northern part of the mining district, just north of several of the major gold mines.

(2) Lead content varies from 0 to about $1 / 2$ percent and is highest in the center of the mining district, in the high-gold-producing area. Zinc is generally very low and follows the distribution of lead. The $\mathrm{Pb}$ and $\mathrm{Zn}$ high values do not overlap those of copper.

(3) By a copper enrichment factor we define as the ratio $\mathrm{Cu} / \mathrm{Cu}+\mathrm{Pb}+\mathrm{Zn}$, a $2 \mathrm{mi}^{2}$ area of strong copper enrichment, values greater than 0.75 , occurs in the northern part of the mining district and includes the area of highest copper values. Areas of $\mathrm{Pb}$ and $\mathrm{Zn}$ enrichment tend to occur peripheral to the area of copper enrichment.

We plan on continuing the study, as we have not yet completely defined the areas of copper enrichment, particularly in the northern part of the district. Our preliminary results do indicate that further evaluation of copper mineralization at depth should be made.

\section{REFERENCE CITED}

Ray, R. G., 1954, Geology and ore deposits of the Willow Creek mining district, Alaska: U.S. Geol. Survey Bull. 1004, 86 p.

LANDSAT data interpretation, Nabesna and McCarthy quadrangIes

By Nairn R. D. Albert

Recent work in the Nabesna and McCarthy quadrangles (fig. 3 (14)) under the Alaskan Mineral Resource Assessment Program (AMRAP) indicates that LANDSAT data can help detect and predict mineral occurrences and provide additional information on geology and structure rele- vant to mineral-resource assessment that may not be acquired by other methods. Visual analysis of false color, "simulated natural color," color ratio, and other computer-enhanced products, in addition to a black and white, single-band photomosaic of Alaska, proved useful when used in conjunction with geologic mapping, geochemical sampling, and aeromagnetic and gravimetric data.

Three nearly orthogonal sets of linears were identified. The predominant set trends approximately N. $43^{\circ} \mathrm{W}$. and N. $48^{\circ}$ E., the other sets approximately N. $72^{\circ}$ W. and N. $20^{\circ}$ E. and N. $87^{\circ}$ E. and north. Parallel linears trending N. $43^{\circ} \mathrm{W}$., N. $48^{\circ}$ E. or N. $87^{\circ} \mathrm{E}$. are spaced approximately $30-35 \mathrm{~km}$ apart. The significance of this regularity is unclear but it may be related to crustal thickness (Vogt, 1974).

The correspondence of known mineral occurrences to linear features in the Nabesna and McCarthy quadrangles is very good. Of 257 known mineral occurrences (Richter and others, 1975; MacKevett and Cobb, 1972; MacKevett, unpublished), 141 (55 percent) occur within $1 \mathrm{~km}$ of a linear feature. Of these 257 occurrences, 124 are prospects or mines, 78 (63 percent) of which occur within $1 \mathrm{~km}$ of a linear feature. Of the 124 prospects or mines, 17 are mines, 14 (82 percent) of which occur within $1 \mathrm{~km}$ of a linear feature.

Circular features identified north of the Denali fault can be correlated with aeromagnetic and geologic data, which suggests that these features may be related to concealed intrusive bodies. Between the Denali and Border Ranges faults, circular features, some nearly $200 \mathrm{~km}$ in diameter, appear to be related to volcanic activity. The relation of circular features to mineralization is not yet clear.

Color anomalies in the Nabesna quadrangle identified on LANDSAT imagery correspond well with known mineral deposits and geochemical anomalies. Of 120 color anomalies identified, 56 (47 percent) correlate with known mineralization and(or) geochemical anomalies. Another 27 (22 percent) occur in areas that have not been sampled geochemically and are considered targets for future exploration.

Other computer-enchanced products include: (1) sinusoidally stretched false color that not only enchances large spectral differences within the image, but also very subtle differences not usually enhanced by other methods; (2) high- and lowfrequency filtration that enhances linear and cir- 
cular features; and (3) a new technique called a "slope stretch" that enhances linear and circular features. Evaluation of these computer enhancement techniques is still in the early stages, but preliminary data indicate that they will significantly help in telegeologic interpretations.

\section{REFERENCES CITED}

MacKevett, E. M., Jr., and Cobb, E. H., 1972, Metallic mineral resources map of the McCarthy quadrangle, Alaska: U.S. Geol. Survey Misc. Field Studies Map MF-395, scale 1:250,000.

Richter, D. H., Singer, D. A., and Cox, D. P., 1975, Mineral resources map of the Nabesna quadrangle, Alaska: U.S. Geol. Survey Misc. Field Studies Map MF-655-K, 1 sheet, scale 1:250,000.

Vogt, P. R., 1974, Volcano spacing, fractures, and thickness of the lithosphere: Earth and Planetary Sci. Letters, v. 21, p. 235-252.

Relations between Triassic carbonate sabkhas and Kennecotttype copper deposits, Wrangell Mountains

By A. K. Armstrong and E. M. MacKevett, Jr.

Recent investigations indicate that sabkha environments were important in the gcnesis of the Kennecott-type copper ores. The massive chalcocite-rich lodes at Kennecott (fig. 2 (28)) and nearby deposits formed in the lower $110 \mathrm{~m}$ of the Upper Triassic Chitistone Limestone. The Chitistone Limestone, some $700 \mathrm{~m}$ thick, disconformably overlies Nikolai Greenstone (late Middle and(or) early Late Triassic). The lowermost $110 \mathrm{~m}$ of the Chitistone contains three cyclic sequences that consist of shallow subtidal pelecypod limestones grading upward to intertidal laminated stromatolitic microdolomite. The youngest cycle contains sabkha features, mud cracks, pseudomorphs of gypsum, and fossil caliches. This is overlain by shallow marine limestones. Underground studies at the Kennecott mines indicate a stratigraphic relation between ore deposition and the third supratidal cycle. These beds are the zebra horizon of the miners. By certain features, we interpret them as representing sediments that were deposited in a sabkha environment: (1) the sedimentary structures and shape of the dolomiteand calcite-filled vugs, their flat bottom, lenticular, enterolithic shape; and (2) the matrix formed by 50 - to $200-\mu \mathrm{m}$ dolomite rhombs.

The sequence of events for the formation of the zebra beds, as indicated from the study of the polished slabs and thin sections, is believed to be:

(1) The development of a coastal sabkha carbonate sediment offlap facies during Chitistone deposition at a stratigraphic level some 100-120 $\mathrm{m}$ above the Nikolai Greenstone contact.

(2) Sabkha diagenesis of the carbonate sediments of the zebra beds probably included dolomitization of the matrix and the concurrent emplacement of diagenetic gypsum and anhydrite above the saline water table.

(3) The dissolution of the gypsum and anhydrite nodules from the zebra beds. Field and petrographic studies do not clearly define when this event occurred. The outcrop sections have a 0.3 to $0.7-\mathrm{m}$ thick caliche or calcrete bed on top of the sabkha facies. The caliche bed represents a regional development of supratidal vadose weathering and possibly meteoric ground-water penetration and dissolution of the gypsumanhydrite nodules within the sabkha sediments and the development of the vugs.

(4) Deposition of coarse-grained, white, zoned, lipid dolomite on the vug walls. Petrographic evidence does not define the time of this event. The extensive voids created by the removal of the gypsum-anhydrite would indicate that a thick section of sediments above this zone would result in the collapse of the dolomite matrix framework and brecciation of the zebra beds.

It can thus be argued that the partial filling of the vugs by lipid dolomite occurred near the surface in a schizohaline sabkha environment.

(5) The fracturing of the zebra beds at a much later date, possibly in the Late Jurassic-Early Cretaceous, and formation of numerous 10- to $100-\mu \mathrm{m}$-wide fractures. The fractures cut the dolomite matrix and lipid dolomite of the vugs. The deposition of coarse-grained sparry calcite fills the fractures, the remaining central areas within the lipid dolomite-lined vugs, and the intercrystalline porosity between the dolomite rhombs of the matrix.

Our favored hypothesis of ore deposition is that the copper was derived from the subjacent Nidolai Greenstone, a thick, largely subaerial tholeiitic basalt with a high mean copper content of about $160 \mathrm{ppm}$. In south-central Alaska and adjacent Yukon Territory, the Nikolai underlies several thousand square kilometres. Most of it underwent subaerial weathering in Late Triassic and Jurassic time, when it was only locally covered by a marginal sea. It is postulated that highly oxygenated meteoric waters leached copper from the exposed Nikolai terrane and that the copper-rich 
solutions migrated into the sabkha-vuggy calcrete aquifer, where reducing conditions promoted copper precipitation. Such a process could have operated from Late Triassic to near the close of the Jurassic, when it was terminated by activity of a regional orogeny. Residual gypsum-anhydrite in the sabkha sediments may have provided the sulfur for the ore.

Stable isotope, sulfide mineralogy, fluid inclusion, and K-Ar age study of the massive sulfide deposits at Kennecott By M. L. Silberman, R. W. Potter II, and Arie Nissenbaum ${ }^{5}$

As support for the geologic and stratigraphic studies on the Kennecott massive copper sulfide deposits (fig. 2 (28)) near McCarthy by E. M. MacKevett, Jr., and A. K. Armstrong, detailed studies are deing carried out on stable isotopes, sulfide mineralogy, fluid inclusion, and K-Ar age determination. Oxygen and carbon isotopes of carbonate minerals are being investigated by Nissenbaum. Oxygen and deuterium-hydrogen analyses on silicate minerals are being conducted by Alan Mathews of the Hebrew University, Jerusalem, Israel. Sufide mineralogy and fluid inclusion analyses are being done by Silberman.

Twenty-four samples of carbonate minerals from parts of the measured sections of the Chitistone Limestone, the host rock for the ore deposits, and calcite and dolomite from wall rocks and calcite from veinlets that contain disseminated sulfides within and adjacent to the ore bodies, have been analyzed for their isotope compositions of oxgen and carbon. The results indicate that the Chitistone section near the deposits has undergone some depletion of $\mathrm{O}^{18}$. Unaltered parts of the Chitistone have a range in.$\delta \mathrm{O}^{18}(\mathrm{SMOW})$ of +25 to $+20 \%$, which overlaps part of the low range of normal marine carbonates. The carbon isotope composition as $\delta \mathrm{C}^{13}(\mathrm{PDB})$ ranges from +3.7 to $+1.5 \%$, which is, in general, slightly heavier than normal marine carbonates as would be expected in a sabkha or lagoonal environment. The high temperatures and consequently high rates of evaporation in this environment would tend to enrich both $\mathrm{C}^{13}$ and $\mathrm{O}^{18}$ relative to a normal marine carbonate. Since the altered Chitistone carbonate shows a depletion of $\mathrm{O}^{18}$ of 5 to $10 \%$, a fluid of low $\mathrm{O}^{18}$ content and very little carbonate is postulated as the altering agent. Meteoric water similar to the present modern isotopic composition in the region is a good possible candidate.

${ }^{5}$ Weizmann Institute of Science, Rehovot, Israel.
Samples from the Chitistone Limestone near the ore deposits are further depleted in $0^{18}$, with $\delta \mathrm{O}^{18}$ ranging from +22 to $+17 \%$ and have the same $\delta \mathrm{C}^{13}$ as the unaltered samples. Coarse sparry calcite, containing disseminated copper sulfides, shows even greater $\mathrm{O}^{18}$ depletion, with $\delta \mathrm{O}^{18}$ of +18 to $+9 \%$ and, again, about the same $\delta \mathrm{C}_{13}$ as the unaltered samples. On the evidence of the small number of gangue samples analyzed to this time (4), we cannot claim that there is an areal variation of the $\delta \mathrm{O}^{18}$ relative to the ore bodies. The stable isotope relations do indicate that the copper sulfides were deposited, at least the last time, by a fluid of very low $\delta \mathrm{O}^{18}$, probably similar to modern meteoric water.

Sulfide mineralogical analyses by Potter indicate that the deposit originally formed as a pyrite-chalcopyrite-bornite-covellite-luzonite assemblage, implying a low temperature of formation. Textural evidence is suggestive of complex multistage processes in the replacement of the original assemblage by chalcocite, djurleite, digenite, anilite, blaubleiblender covellite, and normal covellite. The resulting assemblage indicates temperatures of formation less than $90^{\circ} \mathrm{C}$. Fluid inclusions from calcite associated with and including copper sulfides have average homogenization temperatures of about $50^{\circ} \mathrm{C}$. In general, the results of both stable isotope and fluid-inclusion studies indicate that cool, relatively dilute waters strongly depleted in $\mathrm{O}^{18}$ were responsible for at least the last stages of ore deposition.

We have not been successful in obtaining a mineralization age for the ore deposit. No K-bearing phases are present in the ore bodies, nor in the altered wall rocks surrounding them. A sample of K-silicate altered Nikolai Greenstone, caught as a wedge in a thrust fault exposed about half a kilometer from one of the ore bodies, yielded a K-feldspar age of $180 \mathrm{~m} . \mathrm{y}$. We tentatively interpret this as a deuteric alteration age of the greenstone, since the $\mathrm{K}$-silicate assemblage implies a much higher temperature of alteration than is indicated for the copper sulfide deposition. A mass of rhyolite porphyry as a $2-\mathrm{km}$-long subvolcanic intrusive is exposed $2 \mathrm{~km}$ south of the ore deposits. Smaller masses of porphyry, some hydrothermally altered, are exposed regionally. The porphyry $2 \mathrm{~km}$ from the ore bodies gave a crystallization age of $6.5 \pm 0.2 \mathrm{~m} . \mathrm{y}$.

A suggestion for the origin of the ore deposits as they are presently constituted is that a meteoric 
water circulation cell could have been set up by these igneous masses, thereby causing modification of the already present ore deposits localized in the sabkha facies. Stable isotope analyses of altered porphyry minerals, chlorite, sericite, and $\mathrm{K}$-feldspar, are being done to see if the fluids involved in altering the igneous rocks can be related to those responsible for the existing ore deposits.

Ash flows associated with Wrangell Volcano.

By Thomas P. Miller and Robert L. Smith

Ash-flow tuffs have been found on the southern slopes of Wrangell Volcano (fig. 2 (27)), a snowcovered shield volcano, summit elevation of $4,317 \mathrm{~m}$, located about $80 \mathrm{~km}$ east of Glennallen in the Wrangell Mountains of east-central Alaska. Wrangell Volcano has a pear-shaped summit caldera about $6.5 \mathrm{~km} \times 3.5 \mathrm{~km}$ in diameter that is largely filled with ice and snow; intracaldera cones, two of which are in a fumerolic stage, occur in the west and north parts of the caldera.

Ash-flow outcrops were found south of the volcano in the Kotsina River, the Chetaslina River and its East Fork, and in two unnamed rivers to the west of the Chetaslina at distances as great as $50 \mathrm{~km}$ from the caldera rim. The ash-flow sheets, presumably part of the caldera-forming eruption, probably reached as far as the present course of the Copper River, as ash flow tuffs are found within 1.5 $\mathrm{km}$ of the river. The ash flows are as much as $20 \mathrm{~m}$ thick and in several places are overlain by basalt flows. They range in composition from andesite to dacite and consist of bombs and fragments of scoria, glass, and pumice in a poorly sorted, nonwelded ash matrix. A C-14 age of $1,760 \pm 200$ years B.P. has been obtained (Meyer Rubin, written commun., 1975) from charcoal in a soil horizon overlying a 60-150-cm-thick mud flow which in turn overlies an ash-flow tuff. This is a minimum age for the ash flow; the actual age is thought to be not much older.

Engineering geology of the Greater Anchorage Area Borough By Ernest Dobrovolny and Henry R. SchmolI

Age determinations by uranium and radiocarbon methods on the same shell samples from the Bootlegger Cove Clay are in substantial agreement, further confirming a 14,000-year age (Schmoll and others, 1972). It follows that the Elmendorf moraine is latest Wisconsin, and that the older glacial deposits in the lowland represent the main Wisconsin rather than pre-Wisconsin glaciation.
Many lakes in the mountain valleys are confined by large landslides and rockslides of Holocene age rather than by moraines.

Reports on geology and water resources provided by the U.S. Geological Survey have been utilized by the Planning Department of the Greater Anchorage Area Borough (fig. 3 (16)) in a variety of ways ranging from subdivision review and analysis to the preparation of a comprehensive plan for development of the entire Borough. A subdivision ordinance on hillside development requires in-depth review of the effects of topography, geology, hydrology, and engineering where the terrain has slopes exceeding 25 percent. On more gently sloping ground, subdivision development is modified to conform to geologic and hydrologic constraints. Development of the comprehensive plan used the U.S. Geological Survey reports (Schmoll and Dobrovolny, 1972a, b, 1974; Zenone and others, 1974) as guidelines for certain longrange projections of community needs. These included: (1) development of additional water-supply facilities, such as dam-site locations, and reservation of land for artificial ground-water recharge, (2) location of sites for waste disposal, and (3) selection of open-space areas.

\section{REFERENCES CITED}

Schmoll, H. R., Szabo, B. J., Rubin, M., and Dobrovolny, E., 1972, Radiometric dating of marine shells from the Bootlegger Cove Clay, Anchorage area, Alaska: Geol. Soc. America Bull., v. 83, p. 1107-1114.

Schmoll, H. R., and Dobrovolny, Ernest, 1972a, Generalized geologic map of Anchorage and vicinity, Alaska: U.S. Geol. Survey Misc. Geol. Inv. Map I-787-A.

1972b, Slope map of Anchorage and vicinity, Alaska: U.S. Geol. Survey Misc. Geol. Inv. Map I-787-B.

1974, Foundation and excavation conditions map of Anchorage and vicinity, Alaska: U.S. Geol. Survey Misc. Geol. Inv. Map I-787-D.

Zenone, Chester, Schmoll, H. R., and Dobrovolny, Ernest, 1974, Geology and ground water for land-use planning in the Eagle River-Chugiak area, Alaska: U.S. Geol. Survey open-file report $74-57,36 \mathrm{p}$.

Geohydrology of the Anchorage area By Chester Zenone

In the Anchorage area (fig. 3 (16)), artificial recharge studies were continued on the Ship Creek alluvial fan. Recharge rates of 4 to $6 \mathrm{Mgal} / \mathrm{d}$ (millions of gallons per day) attained in experiments in two previous summers were repeated at the original 11-acre infiltration pond. Materials in a second infiltration basin, where flooding began in midAugust, were coarser and apparently more permeable than at the first site. Over a 1-month test 
period, recharge rates for the second basin were nearly four times as great as rates for the original basin.

A test-well drilling program and aquifer hydraulics tests were carried out in the lower Ship Creek valley. Proposed expansion of the fishrearing facilities by Alaska Department of Fish and Game depend on the availability of shallow ground water in this area. The interrelation of the ground water and streamflow is not fully defined.

Electrical earth resistivity surveys were conducted in the two study areas discussed above. Qualitative evaluation of these resistivity data indicates the general distribution and extent of shallow alluvial aquifers, critical parameters in hydrologic studies in areas where surficial deposits are a complex mixture of unconsolidated glacial materials.

Water-quality data collection on lakes and streams were increased in 1975 . New well inventories were made south of Rabbit Creek, where ground-water data were previously lacking.

Estimate of time required for natural restoration of the effects of the 1964 earthquake at Portage

By A. T. Ovenshine and Reuben Kachadoorian

At Portage (fig. 2 (30)), the land subsided about 2 $m$ during the Alaskan Earthquake of 1964 (Kachadoorian, 1968; McCulloch and Bonilla, 1970), lowering an area of approximately $18 \mathrm{~km}^{2}$ into the intertidal zone of Turnagain Arm (Ovenshine and others, 1976). Marine waters thus introduced killed forest, shrub, and grassland communities that the area supported, and caused rapid deposition of silt. By 1974 , nearly $20 \times 10^{6}$ $\mathrm{m}^{3}$ of silt had accumulated in a layer averaging $1.5 \mathrm{~m}$ thick on the seaward side of the Seward Highway and $0.9 \mathrm{~m}$ thick on the landward side (Ovenshine and others, 1976). This change in the environment of the Portage area was dramatic and profound, but in the last few years there have been indications that sedimentation has slowed to the point at which revegetation is beginning; grasses of several types have returned and a few willows thought dead have sprouted new growth.

The sequence of events observed and inferredsubsidence $\rightarrow$ inundation $\rightarrow$ vegetation kill $\rightarrow$ deposition $\rightarrow$ revegetation-suggests that natural processes are restoring the Portage landscape to its pre-1964 condition. Available geologic data on preearthquake sediments suggest that the cycle of subsidence and restoration has occurred at least twice previously during late Holocene time (Ovenshine and others, 1976, fig. 3D). Our purpose in this note is to develop a minimum estimate of the time required for restoration based on data from the cycle initiated by the 1964 earthquake.

Data available for use in estimating the rate of sedimentation in the Portage area are: (1) the total subsidence that occurred in $1964,2 \mathrm{~m}$; (2) the rate of sedimentation measured over the interval August $1974-$ August $1975,5 \mathrm{~cm} / \mathrm{yr}$; and (3) total thickness of sediment accumulated to 1974 , $1.55 \mathrm{~m}$. Comparison of the thickness of sediment deposited between March 1964 and August 1974 $(1.55 \mathrm{~m})$ and the thickness added during 1974-75 $(5 \mathrm{~cm})$ indicates a nonlinear buildup of sediment that we assume will continue until a total of $2 \mathrm{~m}$ of sediment has accumulated.

A model for sedimentation derived from these data is shown as figure 18 , a curve providing the total thickness of sediment accumulated at any given time after the onset of deposition in 1964 . The formula for the curve is:

$$
A=S\left(1-\mathrm{e}^{\mathrm{kt}}\right)
$$

where: $A=$ total thickness of sediment accumulated at time $\mathrm{t} ; S=$ total subsidence, $e=2.718$; $k=0.1492$; and $t=$ time in years since 1964 . The constant $k$ was determined at $S=2 \mathrm{~m}, A=1.55 \mathrm{~m}$,

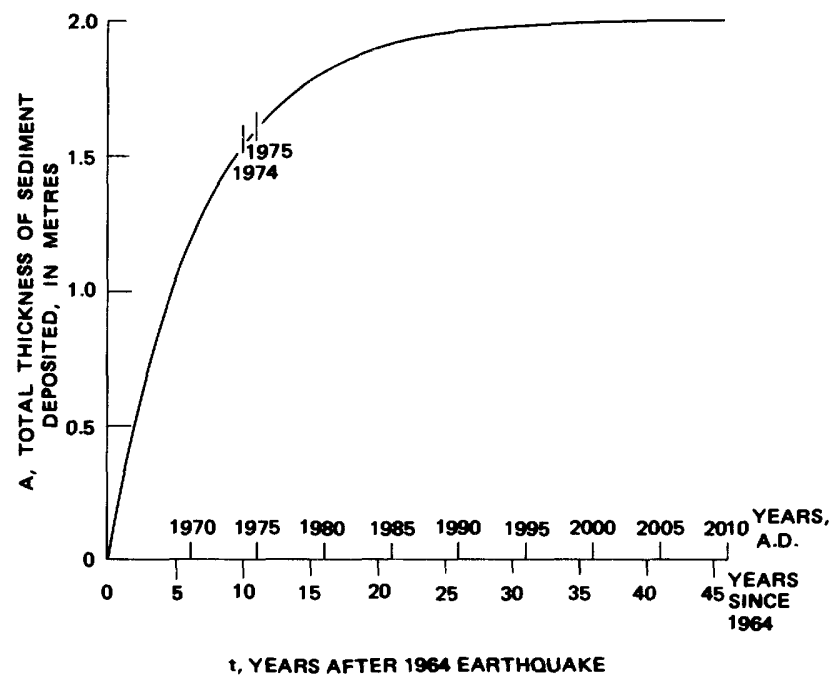

Figure 18.-Curve depicting the rate of buildup of the intertidal sediment surface at Portage. The portion of the curve between years 1974 and 1975 is based on field measurements; the remainder is calculated from the formula developed in this paper. Sedimentation is expected to cease in the early part of the next century as the total thickness of the deposit approaches $2.0 \mathrm{~m}$, the amount the land subsided during the 1964 earthquake. 
and $t=10$ years. Using this formula, $A$ for 11 years (1975) is $1.61 \mathrm{~m}$ or $6 \mathrm{~cm}$ of deposition for the 1-year period 1974-75. This compares favorably with the field measurement of $5 \mathrm{~cm}$ for the same 1-year period. The curve of figure 18 indicates that sedimentation in the Portage area will cease by 2014 ; will be approximately 98 percent complete by 1989 .

A better estimate of the time required for sediment to accumulate to the preearthquake level would require: (1) determining rates of sedimentation at at least 25 additional locations scattered over the Portage area (our estimate of present rates is from measurements at only two sites); (2) considering the effects of increased vegetation density on trapping sediment; (3) evaluating the possibility that depocenters shift landward as filling progresses; and (4) further and more refined analysis and modeling. Without these refinements, we suspect our estimate of 45 years until cessation of sedimentation is correct only within a factor of 2 .

Although we can develop only an estimate of the time required for natural restoration of the Portage area, our analysis clearly shows that the pulse of sedimentation caused by the earthquake will be of very short duration in comparison to the scale of geologic time.

\section{REFERENCES CITED}

Kachadoorian, Reuben, 1968, Effects of the Earthquake of March 27, 1964, on the Alaska highway system: U.S. Geol. Survey Prof. Paper 545-C, 66 p.

McCulloch, D. S., and Bonilla, M. G., 1970, Effects of the Earthquake of March 27, 1964, on The Alaska Railroad: U.S. Geol. Survey Prof. Paper 545-D, 161 p.

Ovenshıne, A. 'T., Lawson, D. E., and Bartsch-Winkler, Susan, 1976, The Placer River Formation--Intertidal sedimentation caused by the Alaska Earthquake of March 27, 1964: U.S. Geol. Survey Jour. Research (in press).

Lake-level fluctuations, North Kenai area

By G. S. Anderson

In October 1975 the fifth consecutive year of lake level measurements was completed in the North Kenai area (fig. 2 (29)). The lake level of Cabin Lake, one of the two lakes closest to the industrial pumping center, was the only one that in 1975 remained below the 1970 level. A statistical analysis of available data is being performed to determine the correlation between yearly lake level changes, yearly precipitation variability, and proximity of the lakes to the center of industrial pumping.
Summary of geology and coal resources of the Bering River Coal Field

By R. B. Sanders

Evidence collected from the Kushtaka Mountain and Cunningham Ridge blocks of the Bering River Coal Field (fig. 2 (33)) indicates that although large quantities of high-quality coal are present, the coal is so complexly deformed that profitable mining by traditional methods may be difficult. The coal is very low in both sulphur and ash and varies in rank from bituminous $B$ to anthrocite. Locally, it has been "coked" by diabase dikes, but to this time no samples having favorable coking analysis (F.S.I.) have been collected. The coal-bearing Kushtaka Formation has reacted to the extreme regional compression with less competence than the adjacent units, resulting in chevron (accordion) folds which are axially thrusted and limbs rotated such that adjacent limbs appear conformable. The coal, being the least competent material present, has tended to flow into the zones of axial dilation along the crests of the folds with such accompanying attenuation of the coal beds along the limbs that it is better described in such terms as pods, wedges, or lenses, rather than as beds.

Reconnaissance engineering geology and geologic hazards of the Yakutat area

By L. A. Yehle

In the Yakutat area (fig. 2 (38)), surficial deposits of several types and predominantly of glacial origin, possibly more than 335 feet (102 m) in average thickness, probably overlie moderately soft sedimentary rocks of Tertiary age. Some of the deposits are potentially hazardous during large earthquakes such as the five of magnitudes between 7.0 and 8.6 that shook the area between 1893 and 1974. Local effects included severe ground shaking, liquefaction of some deltaestuarine, alluvial, and fine-grained outwash deposits, and extensive fountaining. Earthquakerelated water waves as high as 15 feet $(4.6 \mathrm{~m})$ were reported. Landslides and the break-out of glacierdammed lakes are nonearthquake-related hazards that affect nearby areas. The data on which these conclusions are based are contained in a recent open-file report (Yehle, 1975).

\section{REFERENCE CITED}

Yehle, L. A., 1975, Preliminary report on the reconnaissance engineering geology of the Yakutat area, Alaska, with emphasis on evaluation of earthquake and other geologic hazards: U.S. Geol. Survey open-file report 75-529, 130 p. 
Gulf of Alaska seismicity

By John C. Lahr and Michael Blackford

The installation of 12 new seismic stations during the 1974 field season in the coastal zone between Prince William Sound and Yakutat Bay, Alaska, provided for the first time data sufficient to investigate the microearthquake activity there. Sykes (1971) and Kelleher and his coworkers (1973) have labeled this zone as a "seismic gap," or region of current low seismicity bounded by the 1964 Alaskan earthquake ( $M=8.3$ ) rupture on the west and by the 1958 Fairweather fault rupture $(M=7.9)$ on the east. The most recent major $(M>8)$ events within the gap were in 1899 and 1900 . The zone therefore is suspected to be an area of high stress concentration.

In April 1970 a sequence of events occurred off the coast of Yakataga. W. H. Gawthrop and R. A. Page relocated these events using a master event technique and found they form a NNE-trending zone $50 \mathrm{~km}$ long and $10 \mathrm{~km}$ wide. This zone parallels the fault-bounded Pamplona Ridge. Analysis by L. L. Kay and J. A. Thomas of data from microearthquakes in the coastal zone from September 1974 through May 1975 indicates that the Pamplona Ridge is seismically quiet at this time.

The most pronounced source of earthquakes we have found forms a northeast-trending zone extending inland from Icy Bay approximately $75 \mathrm{~km}$. There is scattered activity along the Chugach Mountains between Cordova and Yakutat Bay. The northern part of the Fairweather fault passes through our network and is not a source of many events.

Fewer earthquakes have been located offshore than onshore, in part because of the onshore location of our seismograph network. The highest concentration of offshore events forms a tight cluster $50 \mathrm{~km}$ due south of Yakutat.

The significance of seismicity in the Gulf of Alaska merits close attention in the light of possible continental shelf oil leases. Our research is funded in part by NOAA that we may better evaluate the hazards that pose a threat to the safety of petroleum exploration and development.

\section{REFERENCES CITED}

Kelleher, John, Sykes, Lynn, and Oliver, Jack, 1973, Possible criteria for predicting earthquake locations and their application to major plate boundaries of the Pacific and the Caribbean: Jour. Geophys. Research, v. 78, p. 2547-2585.
Sykes, L. R., 1971, Aftershock zones of great earthquakes, seismicity gaps, and earthquake prediction for Alaska and the Aleutians: Jour. Geophys. Research, v. 76, p. 80218041 .

Submarine mass movement of Holocene sediments seaward of the Copper River

By Paul R. Carlson and Bruce F. Molnia

High-resolution seismic profiles from the continental shelf of the northern Gulf of Alaska show a large submarine slide at the eastern edge of the Copper River (fig. 3 (17)) prodelta. This slide (fig. 19), which has moved down a slope of about $1^{\circ}$ to the bottom of Kayak Trough, is $17 \mathrm{~km}$ in length, 12 $\mathrm{km}$ in maximum width, and has a minimum thickness of $115 \mathrm{~m}$. The estimated volume of material affected is approximately $5.9 \times 10^{11} \mathrm{~m}^{3}$. In addition to very irregular surface morphology and disrupted internal reflectors, this massive slide has a fairly well preserved pull-apart scarp with a relief of about $10 \mathrm{~m}$ and a well-developed toe that is $20 \mathrm{~m}$ thick about $2 \mathrm{~km}$ from the distal end. The toe is partially buried, suggesting a "snowplow" type of movement as the slide moved down the gentle slope into Kayak Trough.

Sediment samples collected with a box corer from the surface of this slide consisted of structureless gray clayey silt of extremely low strength. Laboratory tests with a vane shear apparatus yielded a peak strength of $0.02 \mathrm{~kg} / \mathrm{cm}^{2}$.

Additional evidence of mass movement of Holocene sediment was seen on high-resolution profiles across the entire Copper River prodelta from Kayak Trough to Hinchinbrook Island; the evidence included disrupted bedding and irregular topographic expression. Reimnitz (1972) found similar structures on several profiles obtained from this area shortly after the 1964 Alaskan earthquake. We conclude that these structures were probably caused by the intense ground shaking that accompanied the 1964 Alaskan earthquake.

The Copper River is a major source of Holocene sediment that annually supplies $107 \times 10^{6}$ metric tons of detritus (Reimnitz, 1966). Much of this sediment has accumulated on the prodelta, reaching a maximum thickness of $355 \mathrm{~m}$ southeast of the main channel and averaging about $150 \mathrm{~m}$ in thickness across the entire prodelta (Carlson and Molnia, 1975). According to Morgenstern (1967), the lag between accumulation and consolidation in regions such as deltas, which have high rates of sedimentation, gives rise to excess pore pressure. 
Underconsolidated sediment is prone to sliding; such effects must be considered in the design of offshore facilities that will no doubt follow the oil and gas lease sales of Gulf of Alaska Offshore Continental Shelf tracts.

\section{REFERENCES CITED}

Carlson, Paul R., and Molnia, Bruce F., 1975, Preliminary isopach map of Holocene sediments, northern Gulf of Alaska: U.S. Geol. Survey open-file report 75-507, 1 sheet, scale 1:500,000.

Morgenstern, N. R., 1967, Submarine slumping and the initiation of turbidity currents, in Richards, A. F., Marine geotechniques: Chicago, Univ. Illinois Press, p. 189-220.

Reimnitz, Erk, 1966, Late Quaternary history and sedimentation of the Copper River delta and vicinity, Alaska: California Univ., San Diego, La Jolla, Ph.D. dissert., 160 p. 1972, Effects in the Copper River Delta, in The great Alaska earthquake of 1964; Oceanography and coastal engineering: Washington, D.C., Natl. Acad. Sci., p. 290302 .

Surface sedimentary units of the northern Gulf of Alaska continental shelf

By Bruce F. Molnia and Paul R. Carlson

Analyses of seismic and sediment information collected from the R/V THOMPSON, NOAA SHIP SURVEYER, and FRS CROMWELL by Bruce F. Molnia and Paul R. Carlson indicated the presence of four major sedimentary units on the sea floor of the continental shelf in the northern Gulf of Alaska (fig. 3 (18)). These units, which are characterized by distinctive morphology in siesmic profile, are: (1) Holocene sediments, (2) Holocene end moraines, (3) Quaternary glacial marine sediments, and (4) Tertiary and Pleistocene lithified deposits.

The ages used to describe this material are based on relative stratigraphic positions and not on isotopic dates. The term Holocene is applied to sediment accumulating today and to end moraines formed in historic time. The term Quaternary is applied to glacial marine deposits interpreted as having been deposited on the continental shelf during Pleistocene time when sea level was lowered eustatically. This unit may include Holocene ice-rafted sediment. Tertiary and Pleistocene ages are applied to the stratified sedimentary rocks, which are at many places folded, faulted, and trun-

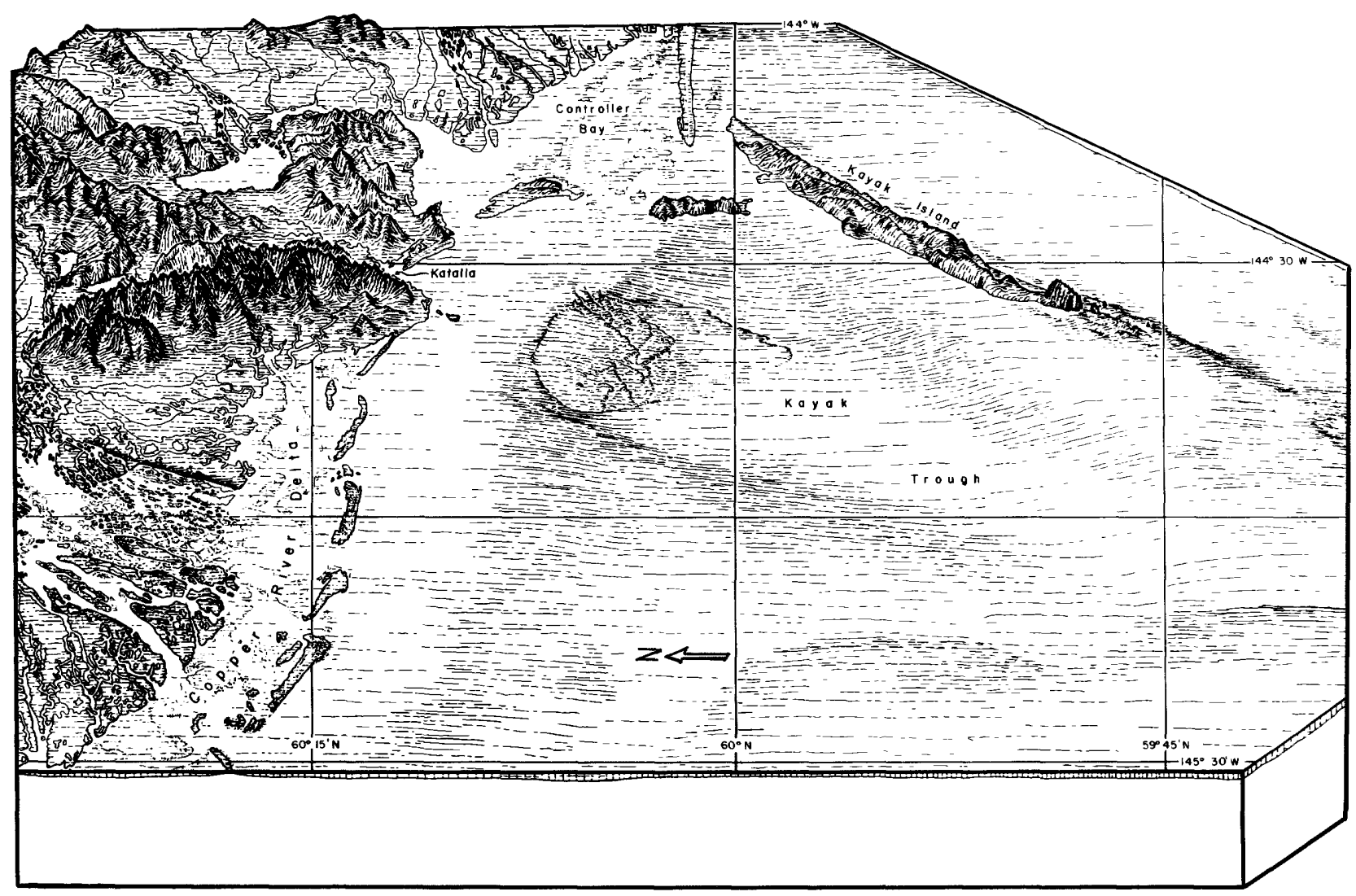

FiguRe 19.-Large submarine slide on Holocene sediment into Kayak Trough. Orthographic drawing by Tau Rho Alpha. 
cated. These rocks are similar in lithology and structure to onshore lithified deposits. Stratigraphically, Holocene sediment overlies Quaternary glacial marine sediment or Tertiary and Pleistocene lithified deposits. Quaternary glacial marine deposits overlie the lithified material.

Holocene sediment blankets the entire nearshore area between Hinchinbrook Island and the south end of Kayak Island. And Holocene sediment forms the surface fill in the Hinchinbrook Seavalley and covers the area south of Tarr Bank and north of Middleton Island. East of Kayak Island, Holocene sediment blankets the nearshore area except for Holocene morainal areas at Icy Bay and the Bering Glacier, and an area of Tertiary and Pleistocene bedrock that crops out southwest of Cape Yakataga between Cape Suckling and Icy Bay. Holocene sediment occurs in a series of isolated pods toward the outer edge of the continental shelf. Characteristically, Holocene sediment is well stratified with continuous reflectors extending for many kilometres. Maximum thicknesses observed are greater than $350 \mathrm{~m}$.

Holocene end moraines are found at the mouth of Icy Bay and south of Bering Glacier and may lie south of the Malaspina Glacier and at the mouth of Yakutat Bay. In seismic profile, end moraines have very irregular surfaces with hummocky lobes exhibiting rapid changes in depth; they typically show discontinuous subbottom reflectors. Pockets of flat-lying sediment are frequently found ponded behind morainal lobes.

Quaternary glacial marine sediments are found in a narrow arc that borders the north and west sides of Tarr Bank and in a large arc $20 \mathrm{~km}$ or more offshore that parallels the shoreline between Kayak Island and Yakutat Bay. In profile glacial marine sediments show many hummocky discontinuous subbottom reflectors. In many places, glacial marine sediments have filled parts of glacially carved U-shaped bedrock valleys.

Tertiary or Pleistocene stratified sedimentary rocks, in profile commonly folded, faulted, and truncated, crop out on Tarr Bank, offshore of Montague Island, and in several localities southeast and southwest of Cape Yakataga.

Five open-file reports dealing with the distribution of surficial units, thickness of Holocene sediments, structure, bathymetry, and the distribution of near-surface faults and slumps were released during 1975.

\section{SOUTHEASTERN ALASKA}

Late Holocene offset features along the Fairweather fault By George Plafker, Travis Hudson, and Meyer Rubin

As part of the Alaska geologic earthquake hazards project, detailed studies were made of offset stream courses and lateral moraines along the trace of the Fairweather fault southeast of Lituya Bay (fig. 2 (39)). These studies focused on the few segments along the prominent trench that marks the fault for $230 \mathrm{~km}$ from Palma Bay on the southeast to Hubbard Glacier on the northwest, where the trace is not concealed by glacier ice, water, or alluvium. During the Lituya Bay earthquake ( $M=7.9$ ) of July 9, 1958, movement probably occurred along the entire onshore length of the Fairweather fault with maximum measured displacements of $6.5 \mathrm{~m}$ dextral slip and $1 \mathrm{~m}$ dip slip near Crillon Lake (Tocher, 1960). On the basis of geomorphic observations at Crillon Lake and the 1958 displacements, Page (1969) deduced a dextral displacement rate of $4 \mathrm{~cm} / \mathrm{yr}$ since deglaciation, approximately 1,000 years ago.

Our field studies show that streams near Crillon Lake that flow on glacial till and bedrock have systematic dextral displacements of $50-60 \mathrm{~m}$ and that a lateral moraine of Finger Glacier southeast of Crillon Lake appears to have been offset about $50 \mathrm{~m}$ in the same sense. Radiometric dating of wood from moraines near Crillon Lake and at Finger Glacier indicates that the offset stream drainages are probably not older than 940 years B.P. and that the offset lateral moraine is about 1,300 years old. These data indicate that the minimum displacement rate along this part of the Fairweather fault for the last millenium was at least $5 \mathrm{~cm} / \mathrm{yr}$, an amount approximately equal to the full relative displacement rate of about 5.3 $\mathrm{cm} / \mathrm{yr}$ between the Pacific and North American plates in the Gulf of Alaska region that has been deduced from deep sea paleomagnetic data (LePichon, 1968).

The new offset data imply that the Fairweather fault is presently a transform boundary along which most, if not all, of the relative motion between the Pacific and North American plates is currently being taken up. Major valleys that cross the Fairweather fault and are probably older than Sangamon appear to be systematically offset in a dextral sense approximately $5 \mathrm{~km}$. This suggests that the present high displacement rate was begun only about 100,000 years ago and implies that 
prior to that time the relative motion between the plates was probably taken up on one or more submarine faults.

\section{REFERENCES CITED}

LePichon, Xavier, 1968, Sea-floor spreading and continental drift: Jour. Geophys. Research, v. 73, no. 12, p. 3661-3697.

Page, Robert, 1969, Late Cenozoic movement on the Fairweather fault in southeastern Alaska: Geol. Soc. America Bull., v. 80, no. 9, p. 1873-1878.

Tocher, Don, 1960, The Alaska earthquake of July 10, 1960Introduction: Seismol. Soc. America Bull., v. 50, no. 2, p. 217-220.

Miocene mollusks from the Topsy Formation, Lituya district By Louie Marincovich

The first find of well-preserved fossils from the Topsy Formation of the Lituya district, Gulf of Alaska Tertiary Province, indicates the approximate age and depositional environment of the rocks. The fauna, collected from four localities by George Plafker and Louie Marincovich, consists of 22 molluscan taxa, represented by numerous specimens, and one fish vertebra.

The Topsy Formation consists of about 1,200 feet (366 $\mathrm{m}$ ) of hard calcareous siltstone and sandstone that crops out intermittently for $30 \mathrm{mi}(48 \mathrm{~km})$ in coastal mountains from Lituya Bay south to Icy Point (fig. 3 (22)). On the basis of very poorly preserved and fragmental molluscan remains, the strata were thought to be marine and of probable Oligocene or Miocene age (Plafker, 1971). Because the rocks are well indurated, they were thought to be older than the bulk of the middle Miocene to Pleistocene Yakataga Formation and probably in part correlative with the underlying Oligocene to lower Miocene Poul Creek Formation.

Several molluscan species in the Topsy fauna are useful in delimiting age relations, including the gastropods Natica (Cryptonatica) clausa (Broderip \& Sowerby), N. (C.) oregonensis (Conrad), Fusitriton oregonensis (Redfield), and the bivalve Acila (Truncacila) taliaferroi Schenck. Taken together, these suggest a middle Miocene age for the Topsy strata. This age determination places the Topsy beds correlative with the lowermost Yakataga Formation, rather than with the underlying Poul Creek rocks. In turn, this refutes the previously considered correlation of the Topsy beds with the Cenotaph Island volcanic sequence, thought to be of early Miocene or possibly Oligocene age.
Bivalves are the dominant element in the Topsy fauna, as they are in many other deposits throughout the Gulf of Alaska Tertiary province. Most of the bivalves are articulated, with closed valves, and are generally not broken or badly abraded, strongly suggesting that they were not transported any significant distance before final burial. Species in the Topsy fauna that are still living or that have very similar living analogues include the bivalves Periploma (Aelga) cf. P. (A.) besshoensis (Yokoyama) and Spisula addicotti Kanno, and the gastropod Fusitriton oregonensis (Redfield). The sum of their known bathymetric ranges suggests deposition of the Topsy beds in depths of 20 to $90 \mathrm{~m}$, within the upper part of the continental shelf. The Topsy fauna is thus equivalent in paleoecology as well as age to the lower Yakataga Formation.

\section{REFERENCE CITED}

Plafker, George, 1971, Pacific margin Tertiary basin, in Cram, I. H., ed., Future petroleum provinces of North America: Am. Assoc. Petroleum Geologists Mem. 15, p. 120-135.

Glacier Bay National Monument mineral-resource studies recommenced

By David A. Brew, Donald Grybeck, B. R. Johnson, and Constance J. Nutt

The mineral-resource potential studies in Glacier Bay National Monument (fig. 3 (23)) reported on by MacKevett and others (1971) have been recommenced as a result of a U.S. National Park Service plan to include the Monument in the National Wilderness Preservation System. The current project involves both Geological Survey and U.S. Bureau of Mines personnel.

Studies made during summer 1975 were directed mainly toward resampling of selected areas to test the applicability of previously obtained geochemical data and toward reconnaissance geologic mapping and sampling of previously unvisited areas.

Geologic mapping in the area southeast of the Mount Crillon-La Perouse layered gabbro body (Rossman, 1963) and southwest of the Brady Glacier confirmed Rossman's unpublished descriptions of metamorphosed graywacke and slate in that area. Rossman (1963) correlated the unit with the Late Jurassic-Early Cretaceous Sitka Graywacke of northeastern Chicagof Island (Rossman, 1959). Our previous studies (MacKevett and others, 1971; Brew and Ovenshine, 
1974) indicate that the unit extends northwestward throughout the Fairweather Range and that it is unfossiliferous. Travis Hudson (oral commun., 1975) has suggested that the unit correlates with Paleozoic rocks still farther northwest. In the area southeast of the Mount Crillon-La Perouse body, this unit was found to be cut (1) by leucocratic granitic bodies of inferred middle Tertiary age that are surrounded by well-defined low-pressure metamorphic facies series aureoles to a few hundred meters wide, and (2) by at least one newly recognized small layered gabbro body.

Geologic mapping in the upper Wachusett Inlet area exposed by the recent rapid recession of the Plateau Glacier revealed that the highly fractured and altered granitic rocks characteristic of the upper Muir Inlet area extend farther south than previously assumed and that at least one thin (10 $\mathrm{m}$ ) layered hornblende gabbro sill cuts those rocks. This is the first gabbro sill recognized in this part of the Monument.

\section{REFERENCES CITED}

Brew, D. A., and Ovenshine, A. T., 1974, Summary of recent studies in Glacier Bay National Monument, Alaska, in Carter, Claire, ed., U.S. Geological Survey Alaska Program, 1974: U.S. Geol. Survey Circ. 700, p. 53-54.

MacKevett, E. M., Jr., Brew, D. A., Hawley, C. C., Huff, L. C., and Smith, J. G., 1971, Mineral resources of Glacier Bay National Monument, Alaska: U.S. Geol. Survey Prof. Paper 632, $90 \mathrm{p}$.

Rossman, D. L., 1959, Geology and ore deposits of northwestern Chicagof Island, Alaska: U.S. Geol. Survey Bull. 1058-E, p. $139-216$.

1963, Geology and petrology of two stocks of layered gabbro in the Fairweather Range, Alaska: U.S. Geol. Survey Bull. 1121-F, $50 \mathrm{p}$.

Apparent pre-middle Tertiary right-lateral offset on Excursion Inlet fault, Glacier Bay National Monument

By David A. Brew, Christine Carlson, and Constance J. Nutt

The Excursion Inlet fault (fig. 2(40)) is one of the complex of faults that make up the Chatham Strait and Fairweather fault systems (Ovenshine and Brew, 1972; Loney and others, 1975). Near the southeastern corner of Glacier Bay National Monument it cuts mainly lower Paleozoic graywacke, slate, and some volcanic and carbonate rocks (MacKevett and others, 1971; Lathram and others, 1959). The fault has been traced for about $90 \mathrm{~km}$ ( $56 \mathrm{mi}$ ) from its northernmost exposure, where it is apparently truncated by a large granitic body of middle Tertiary age (D. A. Brew and M. A. Lanphere, unpub. data), southsoutheast to the waters of Excursion Inlet and Icy Strait. As the fault apparently does not extend into the lower and middle Paleozoic rocks of Chichagof Island on the south side of the Strait (Loney and others, 1975) it is inferred to be either truncated by another northwest-striking fault beneath Icy Strait (R. W. Couch, unpub. data) or to change strike rather abruptly and continue southeastward to join the Chatham Strait fault (Ovenshine and Brew, 1972).

The present position of an east-west striking dike swarm exposed to the west on the west side of Excursion Inlet and to the east on the northeast side of Icy Strait in the vicinity of triangulation stations MUD and DAY (Lathram and others, 1959 ) indicates about $14 \mathrm{~km}$ (9 mi) of right-lateral offset. The dikes are $10 \mathrm{~cm}$ to $1.3 \mathrm{~m}$ wide, occur in thin-bedded graywacke and slate country rock, and consist of locally composite, locally magnetite-bearing, augite-hornblende and hornblende-augite andesite and diabase.

Studies planned or now in progress will reexamine the apparent northward truncation of the fault and date the dikes; they are expected to result in close bracketing of the age of movement on the fault. The available regional and local evidence suggests that the movement was probably of early Tertiary age (Loney and others, 1967; Ovenshine and Brew, 1972; Brew and Ovenshine, 1974).

\section{REFERENCES CITED}

Brew, D. A., and Ovenshine, A. T., 1974, Summary of recent studies in Glacier Bay National Monument, Alaska, in Carter, Claire, ed., U.S. Geological Survey Alaska Program, 1974: U.S. Geol. Survey Circ. 700, p. 53-54.

Lathram, E. H., Loney, R. A., Condon, W. H., and Berg, H. C., 1959 , Progress map of the geology of the Juneau quadrangle, Alaska: U.S. Geol. Survey Map I-303.

Loney, R. A., Brew, D. A., and Lanphere, M. A., 1967, PostPaleozoic radiometric ages and their relevance to fault movements, northern southeastern Alaska: Geol. Soc. America Bull., v. 78, p. 511-526.

Loney, R. A., Brew, D. A., Muffler, L. J. P., and Pomeroy, J. S., 1975, Reconnaissance geology of Chichagof, Baranof, and Kruzof Islands, southeastern Alaska: U.S. Geol. Survey Prof. Paper 792, 105 p.

MacKevett, E. M., Jr., Brew, D. A., Hawley, C. C., Huff, L. C., and Smith, J. G., 1971, Mineral resources of Glacier Bay National Monument, Alaska: U.S. Geol. Survey Prof. Paper 632, $90 \mathrm{p}$.

Ovenshine, A. T., and Brew, D. A., 1972, Separation and history of the Chatham Strait fault, southeast Alaska, North America: Internat. Geol. Cong., 24th, Montreal, Proc., sec. 3, p. 245-254. 
Key foliated quartz diorite sill along southwest side of Coast Range complex, northern southeastern Alaska

By David A. Brew, A. B. Ford, Donald Grybeck, Bruce R. Johnson, and Constance J. Nutt

The southwestern boundary of the Coast Range batholithic complex southeast and east of Juneau, Alaska, is marked by a 3 - to 8 -km- (2- to 5 -mile-) wide foliated biotite-hornblende quartz diorite sill now believed to be exposed for at least $225 \mathrm{~km}$ ( 140 miles) along strike (fig. 2 (42)). What are probably the northernmost exposures have been mapped as the Mount Juneau pluton (Ford and Brew, 1973; Sainsbury, 1953); they are inferred to connect southeastward with the Speel River-Fords Terror pluton (Brew, 1974; Brew and others, 1975; Brew and others, unpub. data) and that body may in turn connect with a generally similar body in the Port Houghton-Thomas Bay area (A. L. Clark and others, unpub. data).

The sill is generally bordered on the southwest by amphibolite grade schists that are part of the Barrovian sequence of the WrangellRevillagegedo metamorphic belt; their original age is late Paleozoic through Early Cretaceous and the age of metamorphism is probably middle or Late Cretaceous. The sill was metamorphosed along with these rocks and was probably emplaced during the deformation-metamorphism episode. Northeast of the sill are gneiss, schist, and marble of the Coast Range gneiss complex, which are also amphibolite facies. The original age of the rocks of the gneiss complex is uncertain, but sparse evidence suggests they are at least in part late Paleozoic in age. The age of the metamorphism is uncertain, but lacking contrary evidence, it is tentatively considered to be Cretaceous.

The studies of the sill and its surroundings completed to this time show that it is close to and consistently parallels the "Coast Range megalinear," an enigmatic, and probably younger, structure that extends the length of southeastern Alaska (D. A. Brew, unpub. data). The association of these two features and the slight contrast in rock units on either side of the sill suggest that the zone they occupy may have been a significant structural discontinuity for a large part of Mesozoic and Cenozoic time.

\section{REFERENCES CITED}

Brew, D. A., 1974, Preliminary results of studies in the Tracy Arm-Fords Terror Wilderness Study Area, in Carter, Claire, ed., U.S. Geological Survey Alaska Program, 1974: U.S. Geol. Survey Circ. 700 , p. 56 .
Brew, D. A., Ford, A. B., Grybeck, Donald, and Nutt, C. J., 1975, Coast Range transect in Tracy Arm-Fords Terror Wilderness Study Area contains seven major belts of rock, in Yount, M. E., ed., U.S. Geological Survey Alaska Program, 1975: U.S. Geol. Survey Circ. 722, p. 53.

Ford, A. B., and Brew, D. A., 1973, Preliminary geologic and metamorphic-isograd map of the Juneau B-2 quadrangle, Alaska: U.S. Geol. Survey Map MF-527.

Sainsbury, C. L., 1953, Geology of the Olds Mountain-Clark Peak area, Juneau vicinity, Alaska: U.S. Geol. Survey open-file report, $43 \mathrm{p}$.

Aquifer investigations in Mendenhall Valley near Juneau By Gary O. Balding

An 82-foot- deep (25-m) test well and two observation wells ( 70 and 71 feet ( 21.3 and $21.6 \mathrm{~m}$ ) deep) were cased and screened at a potential waterbearing zone in the alluvial deposits in Mendenhall Valley (fig. 2 (41)). Drill cuttings and water samples were collected and analyzed. Several short-term step-drawdown tests were run, but lack of funding prevented further important aquifer tests.

Automated observatory system installed at Sitka Observatory By Willie E. Osbakken

In an effort to improve geomagnetic recording capabilities at Sitka (fig. 2 (43)), automated electronic observatory equipment has been installed. Initial installation was begun in December 1974 by Richard Kuberry aided by Willie Osbakken. In February 1975 Maurice Nelson, of the College Observatory, modified the electronics building and installed equipment to furnish uninterrupted power to the automated system. The Storm and Rapid Run Magnetographs were discontinued but the Normal Magnetograph was left in operation to assure continuity of observational baselines and data. The new systems essentials are: two magnetometers, a digital data logger, a magnetic tape recorder, and an analog recorder. A triaxial fluxgate magnetometer monitors the geomagnetic field along orthogonal axes. Total field intensity is provided with a proton resonance magnetometer. Real time analog information is displayed on a strip chart recorder operating directly from the fluxgate magnetometer. The digital output of the proton magnetometer is converted to an analog signal and is displayed on the same recorder. Digital data are recorded on magnetic tape in computer-compatible format. The fluxgate magnetometer is a model FM-100 manufactured by EDA Electronics Ltd. of Canada and was modified to give a range of \pm 1500 gammas. The Geometrics 
Model G826T proton magnetometer is capable of giving $1 / 4$ gamma resolution but is currently being operated in the 1-gamma mode. The data logger is a Monitor Labs Model 9400 capable of handling 10 channels of analog input; at present only 4 are being used. A data scan is made every 10 seconds and the data stored on the Digi-Data Model 1337 7-track tape recorder. Analog data is displayed on a Soltec Model B-4061 strip-chart recorder. Except for a few problems caused by lightning and component failure, the system has been operating quite well. Continuity of recording and baseline control are highly acceptable.

\section{Limnological investigations in southeastern Alaska} By G. A. McCoy

The water quality of six lakes in southeastern Alaska was tested as part of hydrological studies for fisheries enhancement. Low productivity is indicated by low specific conductance, the small amounts of suspended chlorophyll and nutrients, and low dissolved-solids contents. The water in all of the lakes except Redoubt circulates to the lake bottoms (holomictic) twice a year (dimictic). Redoubt Lake is meromictic in that it has an isolated anoxic basal zone that does not circulate (monimolimnion). With the exception of Redoubt Lake, all these lakes are well oxygenated to the bottom or to a depth of $100 \mathrm{~m}$ in those lakes deeper than $100 \mathrm{~m}$. Redoubt Lake (fig. 2 (44)) is believed to be a relict fiord that was isolated from the sea by uplift about 700 years ago. Two reports on this work will be released in the spring of 1976 .

Progress report on geologic investigations in the Craig quadrangle

By G. Donald Eberlein and Michael Churkin, Jr.

The 1975 field program of the Craig quadrangle (fig. 3 (24)) geologic mapping project was focused principally upon extending previously obtained detailed and semidetailed shoreline control inland into the remote and commonly poorly exposed parts of Prince of Wales and adjacent islands within the quadrangle boundaries. During the month of July, H. C. Berg, R. L. Elliott, and two assistants extended mapping of the AnnetteGravina Islands belt into the Craig $\mathrm{C}-1, \mathrm{D}-1$, and part of the D-2 quadrangle. Their work was facilitated by the use of a helicopter and chartered motor vessel. Using the Survey's R/V DON J. MILLER II as a base for helicopter-supported op- erations from August 18 to September 21, G. Donald Eberlein, Michael Churkin, Jr., and two assistants completed field geologic mapping of the interior areas of Prince of Wales, Suemez, Sukkwan, Noyes, Baker, Lulu, and San Fernando Islands. As a result of these combined efforts, it is felt that field geologic control adequate for the preparation of an up-to-date 1:250,000-scale geologic map has now been completed.

The recently completed mapping has resulted in some modification of our earlier views concerning stratigraphic relations among certain previously described units. In the Heceta Island area, along the west coast of Prince of Wales Island, the Upper Silurian through Lower Devonian interval is represented by two formations: the Heceta Limestone, a thick biogenic limestone formation; and the overlying Karheen Formation, a predominantly clastic unit with red-bed affinities (Eberlein and Churkin, 1970). Mapping last season in conjunction with paleontologic studies by N. M. Savage, University of Oregon, has shown that east of Heceta Island toward the interior of Prince of Wales Island, the limestone and red-bed lithologies of the Heceta Limestone and Karheen Formation are interlayered and fossils characteristic of each occur together in a sequence that is cyclically repeated. This sequence is considered to be a new, as yet unnamed, formation. We believe the indicated dramatic facies change reflects sedimentation in a basin off the flank of a large volcanic center, dominated by andesitic and basaltic lithologies, that radiometric and paleontologic dating indicate was active during Late Ordovician-earliest Silurian time.

Volcanic rocks identified with the center were first recognized in the nearby Kogish MountainStaney Cone area of the Craig C-4 quadrangle (Churkin and Eberlein, 1975) and consist mainly of breccia. The breccia is now known to underlie most of the Craig C-3 and D-3 quadrangle as well as the $\mathrm{C}-2$ quadrangle. In places the breccia is crudely layered and appears to be locally interbedded with lithofacies of the Descon Formation (Eberlein and Churkin, 1970). Elsewhere the rocks are more massive and appear to be intrusive.

In addition to supporting the major mapping effort, the availability of the R/V DON J. MILLER II and a helicopter made it possible for Dr. Savage to greatly augment his previously acquired condonont and brachiopod collections with additional material from stratigraphic units of Silurian and 
Devonian age. Of particular interest are the preliminary results from one locality within the Karheen Formation that heretofore had been assigned to the Late Silurian on the basis of megafossils collected by Eberlein in 1947 (Kirk and Amsden, 1952). Dr. Savage reports that his new collections have yielded a fauna, including several key forms, that is indicative of a Middle Siegenian (middle Lower Devonian) age. The assemblage is identical to that previously reported in close association with the graptolite Monograptus yukonensis from the Port St. Nicholas slide area approximately $43.5 \mathrm{~km}$ to the southeast (Churkin, Jaeger, and Eberlein, 1970). This supports Eberlein's previously held view that the Karheen Formation on eastern Heceta Island contains the Silurian/ Devonian systemic boundary.

The summer field program and available logistic support enabled Dr. Rob VanderVoo, University of Michigan, to collect some 300 oriented core samples from 44 sites selected to assess the paleomagnetic research potential of dated, unmetamorphosed stratigraphic units that collectively span the Ordovician to Pennsylvanian time interval. Preliminary results obtained by laboratory demagnetization techniques applied to a few carefully selected samples are encouraging and held promise of yielding useful information on indicated paleomagnetic pole positions for at least parts of the time span in question. Such information could have an important bearing on the development of an understanding of the tectonic history of this area in terms of modern plate tectonic concepts.

\section{REFERENCES CITED}

Churkin, Michael, Jr., Jaeger, Herman, and Eberlein, G. D., 1970, Lower Devonian graptolites from southeastern Alaska: Lethaia, v. 3, p. 183-202.

Churkin, Michael, Jr., and Eberlein, G. Donald, 1975, Geologic map of the Craig C-4 quadrangle: U.S. Geol. Survey Geol. Quad. Map GQ-1169, scale 1:63,360.

Eberlein, G. Donald, and Churkin, Michael, Jr., 1970, Paleozoic stratigraphy in the northwest coastal area of Prince of Wales Island, southeastern Alaska: U.S. Geol. Survey Bull. 1284, 67 p.

Kirk, Edwin, and Amsden, T. W., 1952, Upper Silurian brachiopods from southeastern Alaska: U.S. Geol. Survey Prof. Paper 233-C, p. 53-66.

Progress report on geology and mineral resources of the Ketchikan $q$ ddrangle

By H. C. Berg, R. L. Elliott, and R. D. Koch

The Ketchikan quadrangle (fig. 3 (25)) is divided roughly in half by east Behm Canal, a deep, north-trending linear fiord that may mark a major fault (Berg and others, 1976). To the west, the quadrangle is underlain mainly by a broad belt of greenschist to epidote-amphibolite-grade regionally metamorphosed upper Paleozoic and Mesozoic sedimentary and volcanic rocks intruded by numerous granitic dikes, sills, and stocks. To the east, it is underlain mainly by sillimanite-grade metamorphic rocks and by massive to gneissic plutons of the Coast Range Batholith.

Area west of east Behm Canal.-Fieldwork in 1975 consisted of shoreline reconnaissance geologic mapping and geochemical sampling on Cleveland Peninsula and on southwestern Revillagigedo and adjacent islands. Near Clarence Strait and Tongass Narrows, the bedded rocks are chiefly pelitic metasedimentary rocks intercalated with subordinate andesitic metatuff and agglomerate and with minor roundstone metaconglomerate containing conspicuous granitic clasts. Fossils have not been found in this assemblage; it is inferred to be late Mesozoic in age because it is lithically similar to faunally dated rocks nearby on Annette and Gravina Islands (Berg, 1972, 1973). The strata are faulted, isoclinally folded, and regionally metamorphosed to phyllite and finegrained schist containing variable amounts of quartz, sodic plagioclase, epidote-clinozoisite, chlorite, muscovite, biotite, garnet, actinolite, calcite, and graphite. Near some plutonic contacts the phyllite is thermally metamorphosed to hornfels and schist containing randomly oriented porphyroblasts of actinolite, muscovite, biotite, garnet, and, rarely, cordierite. The bedded rocks are intruded by stocks, dikes, and sills of quartz diorite, granodiorite, and quartz monzonite that range in texture from aplitic to feldspar porphyritic and from nonfoliated to gneissic. Many of the stocks are concentrically zoned from a core of nonfoliated quartz monzonite to a rim of foliated feldspar porphyritic granodiorite. Many of the intrusives, particularly the margins of zoned plutons, characteristically contain tiny euhedra of pink garnet. Two of the plutons have been dated at about 87 m.y. by potassium-argon methods (Berg, 1972; J. G. Smith, unpub. data).

Northeast of the belt of recrystallized pelitic and andesitic strata near Clarence Strait and Tongass Narrows, the bedded rocks of Cleveland Peninsula and Revillagigedo Island make up a polymetamorphic, structurally complex assemblage of metapelite, felsic to mafic metavol- 
canic rocks (including pillow flows), marble, and stretched pebble-to-cobble metaconglomerate containing conspicuous granitic clasts. Upper Paleozoic fossils occur in some of the marble, and Upper Triassic fossils have been found in two small outcrops of marble and metapelite, but the stratigraphic relations among the fossiliferous and unfossiliferous units is uncertain. Preliminary lithostratigraphic evidence suggests that at least some of the granite clast-bearing metaconglomerate is intraformational, late Paleozoic in age, and that the granitic clasts are derived from older plutons on Annette (Berg, 1972) or southwestern Revillagigedo Island. The bedded rocks are deformed into isoclinal folds, locally with northeast-dipping semirecumbent and refolded axial surfaces, and cut by numerous faults ranging in dip from shallow northeast to vertical. The regional metamorphic grade increases irregularly from southwest to northeast with accompanying increase in grain size, fissility, and abundance of such metamorphic minerals as biotite, muscovite, garnet, and actinolite-hornblende. Subsequent thermal metamorphism, primarily in aureoles surrounding stocks and batholiths on interior Revillagigedo Island, commonly produces coarse muscovite schist (garbenshiefer) containing porphyroblasts of actinolite and garnet. In Carroll Inlet, this schist forms outcrops containing spectacular rosettes of actinolite crystals to $2 \mathrm{~m}$ in diameter and garnet euhedra as much as $3 \mathrm{~cm}$ in diameter. The latest metamorphic event is greenschist-facies retrogressive metamorphism. Its distribution is still unknown, but it has been observed in scattered localities in George Inlet and Thorne Arm. The metamorphosed strata are intruded by plutons to batholothic size of quartz diorite to quartz monzonite that underlie most of the interior parts of Revillagigedo Island. Preliminary potassium-argon dating indicates that they range in age from about 70 to $80 \mathrm{~m}$.y. (J. G. Smith, unpub. data).

Mineral deposits on Cleveland Peninsula and southwestern Revillagigedo Island include small inactive lode mines that have produced ore containing gold, zinc, copper, lead and silver (Berg and Cobb, 1967). Numerous other occurrences of these commodities, and one of antimony, have been prospected but not mined. Reconnaissance geochemical investigations in 1975 suggest that these lodes are part of a northwest-trending belt several kilometres wide of sulfide-bearing metamorphosed sedimentary and igneous rocks containing traces to possibly economically significant amounts of metals. Some of the most conspicuous sulfide deposits are associated with ironstained pyritic quartz-muscovite-carbonate schist that may be recrystallized sills or flows. The possibility that the mineral deposits are locally remobilized stratabound volcanogenic sulfide deposits is being investigated.

A structural feature of possible regional significance discovered in 1975 is an Upper Cretaceous or older fault zone a kilometre or more wide along Revillagigedo Channel that may be the boundary between two major tectonostratigraphic units in southeastern Alaska (Berg and others, 1972, p. D2). The zone trends northwest, dips about $50^{\circ}$ $\mathrm{NE}$., and has been mapped discontinuously for about $6 \mathrm{~km}$. In most places it consists of recrystallized cataclastic to submylonitic quartz diorite ranging from coarse porphyroclastic breccia to fine-grained schist containing minute augen of bluish quartz. Near Bold Island, the zone is intruded by hydrothermally altered, but relatively undeformed dikes and sills of feldspar-porphyritic, locally garnet-bearing granodiorite inferred to correlate with isotopically (K-Ar) dated 80-90 m.y.-old plutons on southwestern Revillagigedo and adjacent islands (Berg, 1972; J. G. Smith, unpub. data).

Area east of east Behm Canal.-The eastern half of the Ketchikan quadrangle is underlain mainly by metamorphic and plutonic rocks of the Coast Range batholithic complex. Broad structural and lithologic trends are generally north-south throughout much of the area and are similar to those previously mapped in the Granite Fiords area (Berg and others, 1976).

A typical west-east transect from Revillagigedo Channel-east Behm Canal to Portland Canal crosses several characteristic, but irregular and locally discontinuous, belts of rock. The westernmost belt is characterized by a variety of schists with associated marble, which are similar to the schists and marble of southeastern Revillagigedo Island. These schists are largely restricted to the area south of Smeaton Bay and are approximately on trend with their presumed counterparts on Revillagigedo Island.

A relatively continuous belt of amphibolite and amphibolitic gneiss with minor pelitic gneiss lies to the east of the schists. This predominantly amphibolitic terrane is bordered on the northeast by a 


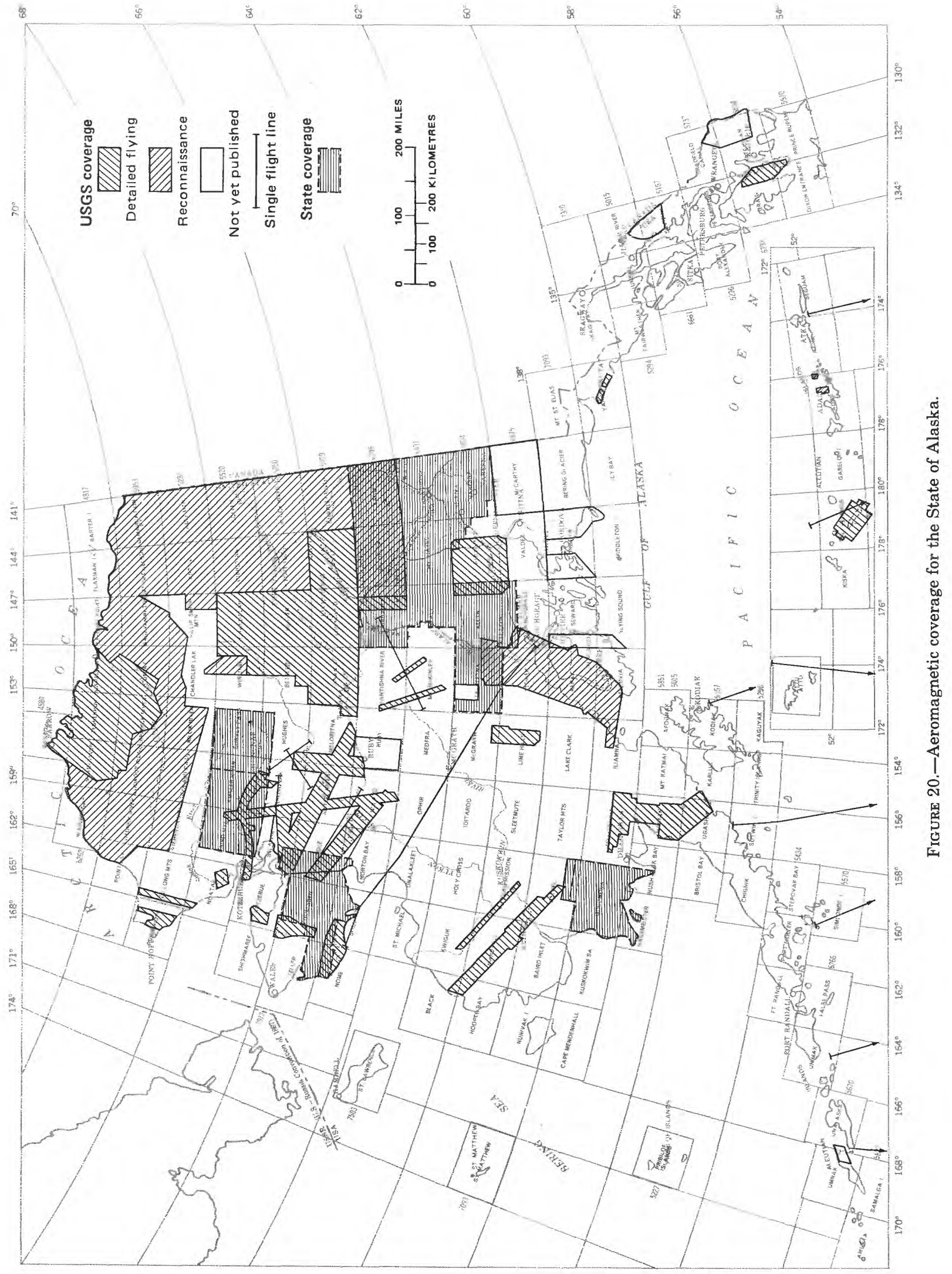


less regular belt characterized by gneisses of granodioritic to quartz dioritic composition that are gradational with foliated granodiorite and quartz diorite.

A discontinuous belt of amphibolite (sillimanite)-grade pelitic gneiss and associated foliated granodiorite is lithologically similar to the paragneiss terrane of the western Granite Fiords area, but is less extensive and less continuous.

The easternmost belt of the series consists of a broad terrane of granodiorite and quartz monzonite plutons. These plutons intrude the foliated plutons and gneisses which lie to the west, and are markedly less foliated and less mafic. Occasional small pendants and screens of paragneiss in this terrane generally trend northeast.

A few small non-foliated plutons of inferred Tertiary age crop out within the gneissic belts of the western half of the region. In at least two instances there is notable mineralization associated with these small plutons.

\section{REFERENCES CITED}

Berg, H. C., 1972, Geologic map of Annette Island, Alaska: U.S. Geol. Survey Misc. Geol. Inv. Map I-684, scale 1:63,360. 1973, Geology of Gravina Island, Alaska: U.S. Geol. Survey Bull. 1373, $41 \mathrm{p}$.

Berg, H. C., and Cobb, E. H., 1967, Metalliferous lode deposits of Alaska: U.S. Geol. Survey Bull. 1246, 254 p.

Berg, H. C., Jones, D. L., and Richter, D. H., 1972, GravinaNutzotin belt-tectonic significance of an Upper Mesozoic sedimentary and volcanic sequence in southern and southeastern Alaska, in Geological Survey research 1972: U.S. Geol. Survey Prof. Paper 800-D, p. D1-D24.

Berg, H. C., Elliott, R. L., Smith, J. G., Pittman, T. L., and Kimball, A. L., 1976, Mineral resources of the Granite Fiords Wilderness Study Area, Alaska: U.S. Geol. Survey Bull. 1403 (in press).

\section{REPORTS ON ALASKA PUBLISHED BY MEMBERS OF \\ THE U.S. GEOLOGICAL SURVEY IN LATE 1974 AND 1975 Compiled by M. E. Tailleur}

Adams, M. V., John, C. B., Kelly, R. F., LaPointe, A. E., and Meurer, R. W., 1975, Mineral resource management of the Outer Continental Shelf: U.S. Geol. Survey Circ. 720, 32 p.

Addicott, W. O., 1974, Recognition and distribution of Mytilus condoni: California Malacozoological Soc., The Veliger, v. 16, no. 4, p. 354-358.

Adkison, W. L., Kelley, J. S., and Newman, K. R., 1975, Lithology and palynology of Tertiary rocks exposed near Capps Glacier and along Chuitna River, Tyonek quadrangle, southern Alaska: U.S. Geol. Survey open-file report 75-21, 58 p., 1 pl.
1975, Lithology and palynologyof the Beluga and Sterling Formations exposed near Homer, Kenai Peninsula, Alaska: U.S. Geol. Survey open-file report 75-383, 244 p. 1 $\mathrm{pl}$.

Ager, T. A., 1975, Late Quaternary pollen record from Birch Lake, Tanana Valley, Alaska: Geol. Soc. America Abs. with Programs, v. 7, no. 3, p. 289-290.

Albert, N. R. D., 1975, Interpretation of Earth Resources Technology Satellite imagery of the Nabesna quadrangle, Alaska: U.S. Geol. Survey Misc. Field Studies Map MF655-J, 2 sheets, scale 1:250,000.

Armstrong, A. K., 1975, Carboniferous corals of Alaska-a preliminary report: U.S. Geol. Survey Prof. Paper 823-C,p. 45-57.

1975, Carboniferous tidal flat deposits of the north flank, northeastern Brooks Range, Arctic Alaska, in Ginsburg, Robert, ed., Tidal deposits - a casebook of recent examples and fossil counterparts: New York, Springer-Verlag, p. 381-386.

1975, Stratigraphy and paleoecology of Carboniferous corals, Lisburne Group, Brooks Range, arctic Alaska: Bull. Am. Paleontology, v. 67, no. 287, p. 17-35.

1975, Depositional environments and facies relations of carbonate rocks, Arctic Alaska, in Recent and ancient sedimentary environments in Alaska: Alaska Geol. Soc. Symposium, Anchorage 1975, Program and Abs., p. 4.

Armstrong, A. K., and Bird, K. J., 1975, Carboniferous environments of deposition and facies, arctic Alaska, in Recent and ancient sedimentary environments in Alaska: Alaska Geol. Soc. Symposium, Anchorage 1975, Program and Abs., p. 4.

Armstrong, A. K., and MacKevett, E. M., Jr., 1975, Relations between Triassic carbonate sabkhas and Kennecott-type copper deposits, Wrangell Mountains, Alaska: Geol. Soc. America Abs. with Programs, v. 7, no. 7, p. 980.

Armstrong, A. K., and Mamet, B. L., 1975, Carboniferous biostratigraphy, northeastern Brooks Range, Arctic Alaska: U.S. Geol. Survey Prof. Paper 884, 29 p.

Averitt, Paul, 1975, Coal resources of the United States, January 1, 1974: U.S. Geol. Survey Bull. 1412, 131 p.

Balding, G. O., 1975, Water-resources data for Skagway, Alaska: U.S. Geol. Survey open-file report, 34 p.

Barnes, D. F., 1975, U.S. Geological Survey Alaskan gravity data maps of the Port Alexander, Sitka, Juneau, Mt. Fairweather, and Skagway 1:250,000 quadrangles, Alaska: U.S. Geol. Survey open-file report $75-6,5$ sheets, scale $1: 250,000$.

1975, Features of a new gravity map of Alaska [abs.]: Am. Geophys. Union Trans., EOS, v. 56, no. 11, p. 900 .

1975, Tectonic interpretation of Bouguer gravity anomalies from the Gulf of Alaska coast [abs.]: Am. Geophys. Union Trans., EOS, v. 56, no. 12, p. 1065.

Barnes, D. F., Erwin, M. J., Holden, K. D., and Morin, R. L., 1975, Additional tabulated gravity data from the Port Alexander, Sitka, Juneau, Mt. Fairweather and Skagway quadrangles, Alaska: U.S. Geol. Survey open-file report 75-6, $58 \mathrm{p}$.

Barnes, D. F., and Morin, R. L., 1975, Gravity map of the Nabesna quadrangle, Alaska: U.S. Geol. Survey Misc. Field Studies Map MF-655-I, 1 sheet, scale 1:250,000.

Barnes, Ivan, and Miller, T. P., 1974, Geothermal studies in Alaska: Geol. Soc. America Abs. with Programs, v. 6, no. 7, p. $645-646$. 
Barnes, P. W., 1975, Preliminary results of marine geologic studies of the northern coast of Alaska, in WEBSEC 71-72, An ecological survey in the Beaufort Sea, Aug.Sept. 1971-1972: U.S. Coast Guard Oceanog. Rept., CG 373-64, p. 183-227.

Barnes, P. W., and Garlow, Richard, 1975, Surface current observations-Beaufort Sea, 1972: U.S. Geol. Survey open-file report 75-619, 8 p., 1 sheet.

Barnes, P. W., and Reimnitz, Erk, 1975, Sedimentary processes on arctic shelves off the northern coast of Alaska, in Reed, J. C., and Sater, J. E., eds., The coast and shelf of the Beaufort Sea: Arlington, Va., Arctic Inst. North America, p. 439-476.

Barnwell, W. W., George, R. S., Dearborn, L. L., Weeks, J. V., and Zenone, Chester, 1972, Water for Anchorage-an atlas of the water resources of the Anchorage area, Alaska: U.S. Geol. Survey open-file report (pub. by the city of Anchorage and the Greater Anchorage Area Borough), 77 p.

Bartsch-Winkler, S. R., and Ovenshine, A. T., 1975, Sedimentological maps of the Girdwood Bar, Turnagain Arm, Alaska, for July-August 1974: U.S. Geol. Survey Misc. Field Studies Map MF-712, 1 sheet, scale 1:24,000.

Bartsch-Winkler, S. R., Ovenshine, A. T., and Lawson, D. E., 1975, Sedimentological maps of the Girdwood Bar, Turnagain Arm, Alaska, for July-August 1973: U.S. Geol. Survey Misc. Field Studies Map MF-672, 1 sheet, scale 1:24,000.

Beikman, H. M., 1975, Preliminary geologic map of southeastern Alaska: U.S. Geol. Survey Misc. Field Studies Map MF-673, 2 sheets, scale 1:1,000,000, prepared in cooperation with the State of Alaska, Department of Natural Resources.

1975. Map of the Alaska Peninsula and Aleutian Islands: U.S. Geol. Survey Misc. Field Studies Map MF-674, 2 sheets, scale 1:1,000,000, prepared in cooperation with the State of Alaska, Department of Natural Resources).

Berg, H. C., and Jones, D. L., 1974, Ophiolite in southeastern Alaska: Geol. Soc. America Abs. with Programs, v. 6, no. 3, p. 144 .

Blazer, A. M., 1975, Index of generic names of fossil plants, 1966-1973: U.S. Geol. Survey Bull. 1396, 54 p.

Brew, D. A., 1975, Preliminary report on plutonic rocks of southeastern Alaska: Circum-Pacific Plutonism Project, 4th Mtg., Vancouver, B.C., Canada, Aug. 1975, unnumbered $p$.

Bruns, T. R., and Plafker, George, 1975, Preliminary structural map of part of the offshore Gulf of Alaska Tertiary Province: U.S. Geol. Survey open-file report $75-508,7$ p., 1 sheet, scale 1:500,000.

Carlson, P. R., 1975, Submarine faults and slides that disrupt surficial sedimentary units, northern Gulf of Alaska: Symposium on Science, Resources, and Technology in the Gulf of Alaska, Anchorage, Oct. 1975, Program, unnumbered p.

Carlson, P. R., Bruns, T. R., and Molnia, B. F., 1975, Submarine slides and nearsurface faults, northern Gulf of Alaska: U.S. Geol. Survey open-file report 75-504, 1 sheet, scale 1:500,000.

Carlson, P. R., and Molnia, B. F., 1975, Preliminary isopach map of Holocene sediments, northern Gulf of Alaska: U.S. Geol. Survey open-file report $75-507,1$ sheet, scale 1:500,000.

1975, Massive submarine slide in the Gulf of Alaska: Geol. Soc. America Abs. with Programs, v. 7, no. 7, p. 1018.
Carter, Claire, and Laufeld, Sven, 1975, Ordovician and Silurian fossils in well cores from North Slope of Alaska: Am. Assoc. Petroleum Geologists Bull., v. 59, no. 3, p. 457-464.

Carter, R. D., Denman, J. M., and Pierpoint, J. G., 1975, Geological literature on the North Slope of Alaska, 1969-1974: U.S. Geol. Survey open-file report 75-384, 83 p.

Chapman, R. M., Yeend, W. E. Brosgé, W. P., and Reiser, H. N., 1975 , Preliminary geologic map of the Tanana and northeastern part of the Kantishna River quadrangles, Alaska: U.S. Geol. Survey open-file report $75-337,1$ sheet, scale $1: 250,000$.

Chapman, R. M., Yeend, W. E., and Patton, W. W., Jr., 1975, Preliminary reconnaissance geologic map of the western half of Kantishna River quadrangle, Alaska: U.S. Geol. Survey open-file report 75-351, 1 sheet, scale 1:250,000.

Childers, J. M., 1975, Channel erosion surveys along southern segment of the TAPS route, Alaska, 1972 and 1973: U.S. Geol. Survey Basic Data report, 57 p.

1975, Experimental trench in armored riverbed in Alaska: Am. Soc. Civil Engineers Proc., Jour. Hydraulics Div., v. 101, no. HY10, p. 1385-1387.

Churkin, Michael, Jr., 1975, Geologic and paleogeographic setting of Paleozoic corals in Alaska: U.S. Geol. Survey Prof. Paper 823-A, p. 1-11.

1975, Basement rocks of Barrow arch, Alaska, and circum-Arctic Paleozoic mobile belt: Am. Assoc. Petroleum Geologists Bull., v. 59, no. 3, p. 451-456.

1975, Paleozoic corals of Alaska-their stratigraphic occurrence and correlation, in Sokolov, B. S., ed., Ancient Cnidaria: Internat. Symposium on Fossil Corals, 1st. Novosibirsk 1971, Proc., v. 2, p. 84-95.

Churkin, Michael, Jr., and Eberlein, G. D., 1975, Geologic map of the Craig C-4 quadrangle, Alaska: U.S. Geol. Survey Geol. Quad. Map GQ-1169, 1 sheet, scale 1:63,360.

Clark, A. L., Berg, H. C., Cobb, E. H., Eberlein, G. D., MacKevett, E. M., Jr., and Miller, T. P., 1974, Metal provinces of Alaska: U.S. Geol. Survey Misc. Inv. Map I-834, 1 sheet, scale 1:5,000,000 (1975).

Cobb, E. H., 1974, Molybdenum occurrences in Alaska: U.S. Geol. Survey Mineral Inv. Resource Map MR-59, 3 p., 1 sheet, scale 1:2,500,000 (1975).

1974, Cobalt occurrences in Alaska: U.S. Geol. Survey Mineral Inv. Resource Map MR-61, 2 p., 1 sheet, scale 1:2,500,000 (1975).

1974, Copper occurrences in Alaska: U.S. Geol. Survey Mineral Inv. Resource Map MR-62, 18 p., 1 sheet, scale 1:2,500,000 (1975).

1974, Nickel occurrences in Alaska: U.S. Geol. Survey Mineral Inv. Resource Map MR-63, 2 p., 1 sheet, scale 1:2,500,000 (1975).

-1974, Tin occurrences in Alaska: U.S. Geol. Survey Mineral Inv. Resource Map MR-65, 4 p., 1 sheet, scale 1:2,500,000 (1975).

1975, Occurrences of platinum-group metals in Alaska: U.S. Geol. Survey Mineral Inv. Resource Map MR-64, 2 p., 1 sheet, scale 1:2,500,000.

1975, Tungsten occurrences in Alaska U.S. Geol. Survey Mineral Inv. Resource Map MR-66, 5 p., 1 sheet, scale $1: 2,500,000$.

1975, Zinc occurrences in Alaska: U.S. Geol. Survey Mineral Inv. Resource Map MR-67, 9 p., 1 sheet, scale $1: 2,500,000$. 
1975, Chromite occurrences in Alaska: U.S. Geol. Survey Mineral Inv. Resource Map MR-68, 2 p., 1 sheet, scale $1 ; 2,500,000$.

1975, Lead occurrences in Alaska: U.S. Geol. Survey Mineral Inv. Resource Map MR-69, 12 p., 1 sheet, scale 1:2,500,000.

1975, Geological Survey and selected U.S. Bureau of Mines and Alaska Division of Geological and Geophysical Surveys reports and maps on Alaska released during 1974, indexed by quadrangle: U.S. Geol. Survey open-file report 75-128, $46 \mathrm{p}$.

1975 , Summary of references to mineral occurrences (other than mineral fuels and construction materials) in the Bendeleben quadrangle, Alaska: U.S. Geol. Survey open-file report 75-429, $122 \mathrm{p}$.

-1975, Summary of references to mineral occurrences (other than mineral fuels and construction materials) in the Teller quadrangle, Alaska: U.S. Geol. Survey open-file report $75-587,141 \mathrm{p}$.

1975 , Summary of references to mineral occurrences (other than mineral fuels and construction materials) in five quadrangles in west-central Alaska (Hughes, Kotzebue, Melozitna, Selawik, Shungnak): U.S. Geol. Survey open-file report $75-627,58 \mathrm{p}$.

1975, Summary of references to mineral occurrences (other than mineral fuels and construction materials) in northern Alaska: U.S. Geol. Survey open-file report 75628, $106 \mathrm{p}$.

Cohee, G. V., and Wright, W. R., 1975, Changes in stratigraphic nomenclature by the U.S. Geological Survey, 1973: U.S. Geol. Survey Bull. 1395-A, 68 p.

1975, Changes in stratigraphic nomenclature by the U.S. Geological Survey, 1974: U.S. Geol. Survey Bull. 1405-A, 36 p.

Connelly, William, and Moore, J. C., 1975, Tectonic mixing during subduction, Kodiak Island, Alaska: Geol. Soc. America Abs. with Programs, v. 7, no. 3, p. 306.

Cooper, A. K., and Scholl, D. W., 1975, Regional crustal inhomogeneities-Bering Sea marginal basin [abs.]: Am. Geophys. Union Trans., EOS, v. 56, no. 12, p. 1187.

Core, Kenneth, Mattick, Robert, and Bayer, Kenneth, 1975, Seismic refraction records from a survey in the Gulf of Alaska: U.S. Geol. Survey open-file report 75-283, 20 p. (19 p. tables).

Dearborn, L. L., and Barnwell, W. W., 1975, Hydrology for land-use planning, the Hillside area, Anchorage, Alaska: U.S. Geol. Survey open-file report 75-105, 46 p.

Detterman, R. L., Reiser, H. N., Brosgé, W. P., and Dutro, J. T., Jr., 1975, Post-Carboniferous stratigraphy, northeastern Alaska: U.S. Geol. Survey Prof. Paper 886, 46 p.

Dobrovolny, Ernest, and Schmoll, H. R., 1974, Slope-stability map of Anchorage and vicinity, Alaska: U.S. Geol. Survey Misc. Geol. Inv. Map I-787-E, 1 sheet, scale 1:24,000 (1975).

Donaldson, D. E., Still, P. J., and Zenone, Chester, 1975, Water-quality data, 1948-1973, Anchorage and vicinity, Alaska: U.S. Geol. Survey open-file report, 59 p.

Donovan, T. J., and Tailleur, I. L., 1975, Map showing paleocurrent and clast-size data from the Devonian-Mississippian Endicott Group, northern Alaska: U.S. Geol. Survey Misc. Field Studies Map MF-692, 1 sheet, scale 1:2,000,000.

Ferrians, O. J., Jr., 1974, Permafrost in relation to climate:
Geol. Soc. America Abs. with Programs, v. 6, no. 7, p. 733.

1975. Special permafrost-related engineering-geologic problems posed by a buried, cold pipeline: Assoc. Eng. Geologists 17th Ann. Mtg., Denver, Colo., Oct. 1974, Program with Abs., p. 24.

Ficke, J. F., and Hawkinson, R. O., 1975, The National Stream Quality Accounting Network (NASQAN)—Some questions and answers: U.S. Geol. Survey Circ. 719, 23 p.

Forbes, R. B., ed., 1975, Contributions to the geology of the Bering Sea Basin and adjacent regions: Geol. Soc. America Spec. Paper 151, 214 p.

Forbes, R. B., Smith, T. E., and Turner, D. L., 1974, Comparative petrology and structure of the Maclaren, Ruby Range, and Coast Range belts; implications for offset along the Denali fault system: Geol. Soc. America Abs. with Programs, v. 6 , no. 3, p. 177.

Forbes, R. B., and Weber, F. R., 1974, Progressive metamorphism of schists recovered from a deep drill hole near Fairbanks, Alaska: U.S. Geol. Survey Jour. Research, v. 3, no. 6 , p. $647-657$.

Freethey, G. W., 1975, Relative permeability of surficial geologic materials, Anchorage and vicinity, Alaska: U.S. Geol. Survey open-file report $75-338,1$ sheet, scale $1: 24,000$.

Grantz, Arthur, Holmes, M. E., and Kososki, B. A., 1975, Geologic framework of the Alaskan continental terrace in the Chukchi and Beaufort Seas, in Yorath, C. J., Parker, E. R., and Glass, D. J., eds., Canada's continental margins and offshore petroleum exploration: Canadian Soc. Petroleum Geologic Mem. 4, p. 669-700.

Grantz, Arthur, and Kirschner, C. E., 1975, Tectonic framework of petroliferous rocks in Alaska: U.S. Geol. Survey open-file report $75-149,44 \mathrm{p}$. including figs.

Griscom, Andrew, 1975, Aeromagnetic map and interpretation of the Nabesna quadrangle, Alaska: U.S. Geol. Survey Misc. Field Studies Map MF-655-H, 2 sheets, scale $1: 250,000$.

Hamilton, T. D., 1974, Geologic setting of early man in Alaska: Geol. Soc. America Abs. with Programs, v. 6, no. 7, p. 773-774.

-1974, Radiocarbon chronology of Alaska; a progress report: Geol. Soc. America Abs. with Programs, v. 6, no. 7, p. 774.

Hawley, C. C., and Clark, A. L., 1974, Geology and mineral deposits of the Upper Chulitna district, Alaska: U.S. Geol. Survey Prof. Paper 758-B, 47 p., plates in pocket (1975).

Hiles, R. M., Gryc, George, Dobey, P. L., and Erwin, M. I., 1975, Developments in Alaska in 1974: Am. Assoc. Petroleum Geologists Bull., v. 59, no. 8, p. 1311-1321.

Hoare, J. M., Coonrad, W. L., Detterman, R. L., and Jones, D. L., 1975, Preliminary geologic map of the Goodnews A-3 quadrangle and parts of the A-2 and B-2 quadrangles, Alaska: U.S. Geol. Survey open-file report 75-308, 15 p., 1 sheet, scale $1: 63,360$.

Hopkins, D. M., 1975, Time-stratigraphic nomenclature for the Holocene: Geology, v. 3, no. 1, p. 10.

Hopkins, D. M., Rowland, R. W., Echols, R. E., and Valentine, P. C., 1974, Anvilian (early Pleistocene) marine fauna from western Seward Peninsula, Alaska: Quaternary Research, v. 4, no. 4, p. 441-470.

Hudson, Travis, 1975, The granite complex of the Serpentine Hot Springs area, Seward Peninsula, Alaska: Geol. Soc. 
America Abs. with Programs, v. 7, no. 3, p. 327-328.

Hudson, Travis, Askevold, Gerald, and Plafker, George, 1975, A computer-assisted procedure for information processing of geologic data: U.S. Geol. Survey Jour. Research, v. 3, no. 3 , p. 369-375.

Hudson, Travis, and Plafker, George, 1975, Intrusive rocks of part of the Chugach and St. Elias Mountains, southern Alaska, in Intrusive rocks and related mineralization of the Canadian Cordillera: Geol. Assoc. Canada, Cordilleran Sec., Vancouver, B.C., Feb. 1975, Program and Abs., p. 17-18.

Hummel, C. L., 1975, Mineral deposits, occurrences, and associated altered rocks in southwest Seward Peninsula, western Alaska: U.S. Geol. Survey open-file report 75-2, 1 sheet, scale 1:125,000.

Imlay, R. W., 1975, Stratigraphic distribution and zonation of Jurassic (Callovian) Ammonites in southern Alaska: U.S. Geol. Survey Prof. Paper 836, 28 p., 6 pls.

Kachadoorian, Reuben, Sainsbury, C. L., and Hummel, C. L., 1975, Analyses of stream sediment samples from the Teller A-3 quadrangle, Seward Peninsula, west-central Alaska: U.S. Geol. Survey open-file report $75-349,51$ p., 1 sheet, scale $1: 63,360$.

Kirschner, C. E., and Grantz, Arthur, 1974, Tectonic framework of petroliferous rocks in Alaska (abs.): Am. Assoc. Petroleum Geologists Bull., v. 58, no. 7, p. 14461447.

Lanphere, M. A., 1975, Plutonism in western United States and Alaska-an overview of geochronology, in Intrusive rocks and related mineralization of the Canadian Cordillera: Geol. Assoc. Canada, Cordilleran Sec., Vancouver, B.C., Feb. 1975, Program and Abs., p. 19-20.

Lathram, E. H., 1974, Aleutian Arc, in Spencer, A. M., ed., Mesozoic-Cenozoic orogenic belts; data for orogenic studies: Geol. Soc. London Spec. Pub. 4, p. 553-561.

Lathram, E. H., Grantz, Arthur, Barnes, D. F., Brew, D. A., Ovenshine, A. T., Plafker, George, Detterman, R. L., Foster, H. L., Churkin, Michael, Jr., Patton, W. W., Jr., Hoare, J. M., Tailleur, I. L., Brosgé, W. P., Miller, T. P., and Sainsbury, C. L., 1974, Alaska, in Spencer, A. M., ed., Mesozoic-Cenozoic orogenic belts; data for orogenic studies: Geol. Soc. London Spec. Pub. 4, p. 563-589.

Lemke, R. W., 1975, Reconnaissance engineering geology of the Ketchikan area, Alaska, with emphasis on evaluation of earthquake and other geologic hazards: U.S. Geol. Survey open-file report 75-250, 68 p., 1 sheet, scale 1:4,800.

Loney, R. A., Brew, D. A., Muffler, L. J. P., and Pomeroy, J. S., 1975, Reconnaissance geology of Chichagof, Baranof, and Kruzof Islands, southeastern Alaska: U.S. Geol. Survey Prof. Paper 792, 105 p., 4 pls., scale 1:250,000.

Luepke, Gretchen, 1975, Heavy mineral trends in the Beaufort Sea: U.S. Geol. Survey open-file report 75-667, 1 sheet, scale 1:700,000.

McCoy, G. A., 1974, Preconstruction assessment of biological quality of the Chena and Little Chena Rivers in the vicinity of the Chena Lakes flood control project near Fairbanks, Alaska: U.S. Dept. Commerce Natl. Tech. Inf. Service., AD-A005085, 90 p. (1975).

MacKevett, E. M., Jr., 1974, Geologic map of the McCarthy B-5 quadrangle, Alaska: U.S. Geol. Survey Geol. Quad. Map GQ-1146, 1 sheet, scale 1:63,360 (1975).

McManus, D. A., Venkatarathnam, Kolla, Hopkins, D. M., and
Nelson, C. H., 1974, Yukon River sediment on the northernmost Bering Sea shelf: Jour. Sed. Petrology, v. 44, no. 4, p. 1052-1060.

Magoon, L. B., Hampton, M. A.. Sable, E. G., Smith, R. A., and Chemlik, F. B., 1975, Hydrocarbon potential, geologic hazards, and the technology, time-frame and infrastructure for exploration and development of the lower Cook Inlet, Alaska-a preliminary assessment: U.S. Geol. Survey open-file report 75-549, $74 \mathrm{p}$.

Marlow, M. S., Alpha, T. R., Scholl, D. W., and Buffington, E. C., 1975, [Physiographic diagrams of the] Bering Sea Shelf, Alaska: U.S. Geol. Survey open-file report 75-1, 2 sheets.

Marsh, S. P., 1975, Geochemical and generalized geologic map showing distribution and abundance of copper in the Nabesna quadrangle, Alaska: U.S. Geol. Survey Misc. Field Studies Map MF-655-B, 1 sheet, scale 1:250,000.

1975, Geochemical and generalized geologic map showing distribution and abundance of lead in the Nabesna quadrangle, Alaska: U.S. Geol. Survey Misc. Field Studies Map MF-655-C, 1 sheet, scale 1:250,000.

1975, Geochemical and generalized geologic map showing distribution and abundance of gold in the Nabesna quadrangle, Alaska: U.S. Geol. Survey Misc. Field Studies Map MF-655-D, 1 sheet, scale 1:250,000.

1975, Geochemical and generalized geologic map showing distribution and abundance of chromium in the Nabesna quadrangle, Alaska: U.S. Geol. Survey Misc. Field Studies Map MF-655-E, 1 sheet, scale 1:250,000. 1975 , Geochemical and generalized geologic map showing distribution and abundance of cobalt in the Nabesna quadrangle, Alaska: U.S. Geol. Survey Misc. Field Studies Map MF-655-F, 1 sheet, scale 1:250,000.

1975, Perspective diagrams showing geochemical abundance of silver, lanthanum, molybdenum, nickel, vanadium, yttrium, and zinc in the Nabesna quadrangle, Alaska: U.S. Geol. Survey Misc. Field Studies Map MF655-G, 1 sheet, scale 1:250,000.

Miller, B. M., 1975, Undiscovered oil and gas: Geotimes, v. 20, no. 9 , p. 23.

Miller, B. M., Thomsen, H. L., Dolton, G. L., Coury, A. B., Hendricks, T. A., Lennartz, F. E., Powers, R. B., Sable, E. G., and Varnes, K. L., 1975, Geological estimates of undiscovered recoverable oil and gas resources in the United States: U.S. Geol. Survey Circ. 725, 78 p.

Miller, D. J., 1975, Geologic map and sections of the central part of the Katalla district, Alaska: U.S. Geol. Survey Misc. Field Studies Map MF-722, 2 sheets, scale 1:40,000.

Miller, T. P., Barnes, Ivan, and Patton, W. W., Jr., 1975, Geologic setting and chemical characteristics of hot springs in west-central Alaska: U.S. Geol. Survey Jour. Research, v. 3, no. 2, p. 149-162.

Miller, T. P., and Bunker, C. M., 1975, U, Th, and K analyses of selected plutonic rocks from west-central Alaska: U.S. Geol. Survey open-file report 75-216, 3 p., 1 fig.

-1975 , A reconnaissance study of the $U$ and Th contents of plutonic rocks of the southeastern Seward Peninsula, Alaska: U.S. Geol. Survey open-file report 75-217, 24 p., 5 figs.

Miller, T. P., and Smith, R. L., 1975, Ash flows on the Alaska Peninsula; a preliminary report on their distribution, composition, and age: Geol. Soc. America, Abs. with Programs, v. 7 , no. 7 , p. 1201 . 
Molnia, B. F., 1975, Surface sediment types of the northern Gulf of Alaska continental shelf [abs.]: Symposium on Science, Resources, and Technology in the Gulf of Alaska, Anchorage, Oct. 1975, Program, unnumbered p.

Molnia, B. F., and Carlson, P. R., 1975, Surface sediment distribution map, northern Gulf of Alaska: U.S. Geol. Survey open-file report 75-505, 1 sheet, scale 1:500,000.

1975, Base map of the northern Gulf of Alaska: U.S. Geol. Survey open-file report $75-506,1$ sheet, scale 1:500,000.

1975, Geology of Pamplona Ridge, northern Gulf of Alaska: Geol. Soc. America Abs. with Programs, v. 7, no. 7, p. 1203.

1975, Shelf sediment distribution; northern Gulf of Alaska [abs.]: Am. Assoc. Petroleum Geologists, Soc. Explor. Geophysicists, Soc. Econ. Paleontologists and Mineralogists, Long Beach, Calif., April 1975, Program, p. 19.

Moore, G. W., 1975, Subduction model suggested by the very thick Kodiak Formation, Alaska: Geol. Soc. America Abs. with Programs, v. 7 , no. 3, p. 350-351.

Moore, J. C., 1974, Geologic and structural map of part of the outer Shumagin Islands, southwestern Alaska: U.S. Geol. Survey Misc. Inv. Map I-815, 1 sheet, scale 1:63,360 ( 1975 ). -1975 , Selective subduction: Geology, v. 3 , no. 9 , p. 530532.

Nauman, J. W., and Kernodle, D. R., 1975, Water-quality changes during a salmon run in an interior Alaskan stream: U.S. Geol. Survey Jour. Research, v. 3, no. 1, p. 103-106.

1975, The effect of a fuel oil spill on benthic invertebrates and water quality on the Alaskan Arctic Slope, Happy Valley Creek near Sagwon, Alaska: U.S. Geol. Survey Jour. Research, v. 3, no. 4, p. 495-500.

Nelson, C. H., 1975, Holocene dispersal of Yukon River sediments in Bering Sea and implications for interpretation of ancient epicontinental shelves, in Recent and ancient sedimentary environments in Alaska: Alaska Geol. Soc. Symposium, Anchorage 1975, Program and Abs., p. 30.

Nelson, C. H., Hopkins, D. M., and Scholl, D. W., 1974, Tectonic setting and Cenozoic sedimentary history of the Bering Sea, in Herman, Y., ed., Arctic marine geology and oceanography: New York, Springer-Verlag, p. 119-137.

1974, Cenozoic sedimentary and tectonic history of the Bering Sea, in Hood, D. W., and Kelley, E. J., eds., Oceanography of the Bering Sea: Inst. Marine Sci., Univ. Alaska Press, p. 485-516.

Nelson, C. H., Larsen, B. L., and Rowland, R. W., 1975, ERTS imagery and dispersal of Yukon and Kuskokwim River sediments in northeastern Bering Sea, in Carlson, P. R., ed., Principal sources and dispersal patterns of suspended particulate matter in nearshore surface waters of the northeast Pacific Ocean and the Hawaiian Islands: U.S. Dept. Commerce Natl. Tech. Inf. Service, ERTS Final Reports, p. 26-40.

Nelson, C. H., Pierce, D. E., Leong, K. W., and Wang, F. F. H., 1975, Mercury distribution in ancient and modern sediment of northeastern Bering Sea: Marine Geology, v. 18, p. 91-104.

Nilsen, T. H., Brabb, E. E., and Simoni, T. R., 1975, The Nation River Formation, a Late Devonian deep-sea fan deposit in east-central Alaska, in Recent and ancient sedimentary environments in Alaska: Alaska Geol. Soc. Symposium, Anchorage 1975, Program and Abs., p. 7.

O'Leary, Richard, and Van Trump, George, Jr., 1975, Magnetic tape containing spectrographic and chemical analyses of stream sediments and rocks from the Nabesna quadrangle, Alaska: U.S. Dept. Commerce Natl. Tech. Inf. Service, PB-240 488/AS, 7 p.

Oliver, W. A., Jr., Merriam, C. W., and Churkin, Michael, Jr., 1975, Ordovician, Silurian, and Devonian corals of Alaska: U.S. Geol. Survey Prof. Paper 823-B, p. 13-44, 25 pls.

1975, Ordovician, Silurian, and Devonian corals of Alaska, in Sokolov, B. S., ed., Ancient Cnidaria: Internat. Symposium on Fossil Corals, 1st Novosibirsk 1971, Proc., v. 2, p. 95-103.

Ovenshine, A. T., 1975, Tidal Origin of parts of the Karheen Formation (Lower Devonian), southeastern Alaska, in Ginsburg, Robert, ed., Tidal deposits-a casebook of recent examples and fossil counterparts: New York, SpringerVerlag, p. 127-133.

Ovenshine, A. T., Bartsch-Winkler, Susan, O'Brien, N. R., and Lawson, D. E., 1975, Intertidal sedimentation in upper Turnagain Arm, Alaska, in Recent and ancient sedimentary environments in Alaska: Alaska Geol. Soc. Symposium, Anchorage 1975, Program and Abs., p. 13.

Ovenshine, A. T., Lawson, D. E., and Bartsch-Winkler, S. R., 1974, Subsidence, inundation, and sedimentation; Environmental consequences of the 1964 Alaska earthquake in the Portage, Alaska area: U.S. Geol. Survey Earthquake Inf. Bull., v. 6, no. 6, p. 3-9 (1975).

Overstreet, W. C., Crenshaw, G. L., Hubert, A. E., Rosenblum, Sam, and Smith, R. J., 1975, Experimental results of atomic absorption analyses for indium and thallium in 803 nonmagnetic concentrates from Alaska: U.S. Geol. Survey open-file report $75-253,78 \mathrm{p}$.

Overstreet, W. C., Hamilton, J. C., Boerngen, J. G., Rosenblum, Sam, Marsh, W. R., and Sainsbury, C. L., 1975, Minor elements in nonmagnetic concentrates from Alaska: U.S. Dept. Commerce Natl. Tech. Inf. Service, PB-238-989/AS, $440 \mathrm{p}$.

Page, R. A., 1975, Evaluation of seismicity and earthquake shaking at offshore sites: Offshore Technology Conf., 7th, Houston, Texas, Proc., v. 3, p. 179-190.

1975, Earthquake activity in the Gulf of Alaska (abs.): Symposium on Science, Resources, and Technology in the Gulf of Alaska, Anchorage, Alaska, Oct. 1975, Program, unnumbered $\mathbf{p}$.

Patton, W. W., Jr., Lanphere, M. A., Miller, T. P., and Scott, R. A., 1974, Age and tectonic significance of volcanic rocks on St. Matthew Island, Bering Sea, Alaska: Geol. Soc. America Abs. with Programs, v. 6, no. 7, p. 905-906.

1975, Age and tectonic significance of volcanic rocks on St. Matthew Island, Bering Sea, Alaska: U.S. Geol. Survey open-file report 75-150, $18 \mathrm{p}$.

Patton, W. W., Jr., Miller, T. P., Berg, H. C., Gryc, George, Hoare, J. M., and Ovenshine, A. T., 1975, Reconnaissance geologic map of St. Matthew Island, Bering Sea, Alaska (with gravity map of St. Matthew and Hall Islands by D. F. Barnes and M. B. Estlund): U.S. Geol. Survey Misc. Field Studies Map MF-642, 1 sheet, scale 1:125,000.

Péwé, T. L., 1975, Quaternary stratigraphic nomenclature in unglaciated central Alaska: U.S. Geol. Survey Prof. Paper 862,32 p. 
1975, Quarternary geology of Alaska: U.S. Geol. Survey Prof. Paper 835, 145 p., 3 pls., map scale 1:5,000,000.

Péwé, T. L., and Bell, J. W., 1975, Map showing distribution of permafrost in the Fairbanks D-2 SW quadrangle, Alaska: U.S. Geol. Survey Misc. Geol. Inv. Map I-829-B, (Folio), 1 sheet, scale 1:24,000.

-1975, Map showing distribution of permafrost in the Fairbanks D-2 NW quadrangle, Alaska: U.S. Geol. Survey Misc. Field Studies Map MF-668-A, 1 sheet, scale 1:24,000.

1975, Map showing groundwater conditions in the Fairbanks D-2 NW quadrangle, Alaska: U.S. Geol. Survey Misc. Field Studies Map MF-668-B, 1 sheet, scale 1:24,000.

1975, Map showing construction materials in the Fairbanks D-2 NW quadrangle, Alaska: U.S. Geol. Survey Misc. Field Studies Map MF-668-C, 1 sheet, scale 1:24,000.

1975, Map showing foundation conditions in the Fairbanks D-2 NW quadrangle, Alaska: U.S. Geol. Survey Misc. Field Studies Map MF-668-D, 2 sheets, scale 1:24,000.

1975, Map showing distribution of permafrost in the Fairbanks D-2 SE quadrangle, Alaska: U.S. Geol. Survey Misc. Field Studies Map MF-669-A, 1 sheet, scale 1:24,000.

1975, Map showing groundwater conditions in the Fairbanks D-2 SE quadrangle, Alaska: U.S. Geol. Survey Misc. Field Studies Map MF-669-B, 1 sheet, scale 1:24,000.

1975, Map showing construction materials in the Fairbanks D-2 SE quadrangle, Alaska: U.S. Geol. Survey Misc. Field Studies Map MF-669-C, 1 sheet, scale 1:24,000.

1975, Map showing foundation conditions in the Fairbanks D-2 SE quadrangle, Alaska: U.S. Geol. Survey Misc. Field Studies Map MF-669-D, 2 sheets, scale 1:24,000.

1975, Map showing distribution of permafrost in the Fairbanks D-2 NE quadrangle, Alaska: U.S. Geol. Survey Misc. Field Studies Map MF-670-A, 1 sheet, scale 1:24,000.

1975, Map showing groundwater conditions in the Fairbanks D-2 NE quadrangle, Alaska: U.S. Geol. Survey Misc. Field Studies Map MF-670-B, 1 sheet, scale 1:24,000.

-1975, Map showing construction materials in the Fairbanks D-2 NE quadrangle, Alaska: U.S. Geol. Survey Misc. Field Studies Map MF-670-C, 1 sheet, scale 1:24,000.

1975, Map showing foundation conditions in the Fairbanks D-2 NE quadrangle, Alaska: U.S. Geol. Survey Misc. Field Studies Map MF-670-D, 2 sheets, scale 1:24,000.

1975, Map showing distribution of permafrost in the Fairbanks D-1 SW quadrangle, Alaska: U.S. Geol. Survey Misc. Field Studies Map MF-671-A, 1 sheet, scale 1:24,000.

1975, Map showing groundwater conditions in the Fairbanks D-1 SW quadrangle, Alaska: U.S. Geol. Survey Misc. Field Studies Map MF-671-B, 1 sheet, scale 1:24,000.

1975, Map showing construction materials in the Fairbanks D-1 SW quadrangle, Alaska: U.S. Geol. Survey Misc. Field Studies Map MF-671-C, 1 sheet, scale 1:24,000.
-1975, Map showing foundation conditions in the Fairbanks D-1 SW quadrangle, Alaska: U.S. Geol. Survey Misc. Field Studies Map MF-671-D, 2 sheets, scale 1:24,000.

Plafker, George, and Addicott, W. O., 1975, Marine glacial deposits of Miocene through Holocene age in the Yakataga Formation along the Gulf of Alaska margin, Alaska, in Recent and ancient sedimentary environments in Alaska: Alaska Geol. Soc. Symposium, Anchorage, 1975, Program and Abs., p. 36.

Plafker, George, and Bruns, Terry, 1975, Tectonic framework and general geology of the Gulf of Alaska Tertiary province, Alaska: Symposium on Science. Resources, and Technology in the Gulf of Alaska, Anchorage, Alaska, Oct. 1975, Program, unnumbered $p$.

Plafker, George, Bruns, Terry, and Page, Robert, 1975, Interim report on petroleum resource potential and geologic hazards in the outer shelf of the Gulf of Alaska Tertiary province: U.S. Geol. Survey open-file report 75-592, 74 p.

Platt, J. B., 1975, Petrography of University of Washington dredge samples for the central Chukchi Sea: U.S. Geol. Survey open-file report $75-269,23 \mathrm{p}$.

Post, A. S., 1975, Preliminary hydrography and historic terminal changes of Columbia Glacier, Alaska: U.S. Geol. Survey open-file report 75-491, 11 p., 2 sheets, scale 1:10,000 and 1:20,000, 1 sheet photos.

Reed, B. L., and Lanphere, M. A., 1974, Offset plutons and history of movement along the McKinley segment of the Denali fault system, Alaska: Geol. Soc. America Bull., v. 85, p. 1883-1892.

Reimnitz, Erk, and Barnes, P. W., 1974, Sea ice as a geologic agent on the Beaufort Sea shelf of Alaska, in Reed, J. C., and Sater, J. E., eds., The coast and shelf of the Beaufort Sea: Arlington, Va., Arctic Inst. North America, p. 301351.

Richter, D. H., 1975, Geologic map of the Nabesna quadrangle, Alaska: U.S. Geol. Survey Misc. Field Studies Map MF655-A. 1 sheet, scale 1:250,000.

Richter, D. H., Albert, N. R. D., Barnes, D. F., Griscom, Andrew, Marsh, S. P., and Singer, D. A., 1975, The Alaskan mineral resource assessment program; background information to accompany folio of geologic and mineral resource maps of the Nabesna quadrangle, Alaska: U.S. Geol. Survey Circ. $718,11 \mathrm{p}$.

Richter, D. H., and Dutro, J. T., Jr., 1975, Revision of the type Mankomen Formation (Pennsylvanian and Permian), Eagle Creek area, eastern Alaska Range, Alaska: U.S. Geol. Survey Bull. 1395-B, 25 p.

Richter, D. H., Lanphere, M. A., and Matson, N. A., Jr., 1975, Granitic plutonism and metamorphism, eastern Alaska Range, Alaska: Geol. Soc. America Bull., v. 86, no. 6, p. 819-829.

Richter, D. H., and Schmoll, H. R., 1973, Geologic map of the Nabesna C-5 quadrangle, Alaska: U.S. Geol. Survey Geol. Quad. Map GQ-1062, 1 sheet, scale 1:63,360 (1975).

Richter, D. H., Singer, D. A., and Cox, D. P., 1975, Mineral resources map of the Nabesna quadrangle, Alaska: U.S. Geol. Survey Misc. Field Studies Map MF-655-K, 1 sheet, scale 1:250,000.

Rodeick, C. A., 1975, Marine gravel deposits of the Beaufort Sea Shelf [abs.] in Reed, J. C., and Sater, J. E., eds., The coast and shelf of the Beaufort Sea: Arlington, Va., Arctic Inst. North America, p. 511. 
Rosenblum, Sam, and Mosier, E. L., 1975, Nonmetamict nioboeschynite-(Ce) from Alaska: Am. Mineralogist, v. 60, nos. 3 and 4, p. 309-315.

Rowett, C. L., 1975, Stratigraphic distribution of Permian corals in Alaska: U.S. Geol. Survey Prof. Paper 823-D, p. $59-73,3$ pls.

Ruppel, B. D., and McHendrie, Graig, 1975, Free air gravity anomaly profiles from the Chukchi Sea: U.S. Geol. Survey open-file report 75-343, profiles with 2 map sheets showing location.

Sando, W. J., 1974, Checklist of North American Late Paleozoic coral species (Coelenterata, Anthozoa): U.S. Geol. Survey Bull. 1387, 36 p. (1975).

Sando, W. J., Bamber, E. W., and Armstrong, A. K., 1975, Endenism and similarity indices; clues to the zoogeography of North American Mississippian corals: Geology, v. 3 , no. 11 , p. $661-664$.

Savage, J. C., 1975, Further analysis of the geodetic strain measurements on the Denali fault, Alaska: Jour. Geophys. Research, v. 80, p. 3786-3790

Scholl, D. W., Marlow, M. S., and Buffington, E. C., 1975, Summit basins of Aleutian Ridge, North Pacific: Am. Assoc. Petroleum Geologists Bull., v. 59, no. 5, p. 799-816.

Scholl, D. W., Marlow, M. S., MacLeod, N. S., and Buffington, E. C., 1975, Episodic igneous activity along the Aleutian Ridge; implications for subduction models: Geol. Soc. America Abs. with Programs, v. 7, no. 3, p. 370-371.

Sloan, C. E., Zenone, Chester, and Mayo, L. R., 1975, Icings along the trans-Alaska pipeline route: U.S. Geol. Survey open-file report $75-87,39 \mathrm{p}$.

Smith, J. G., 1975, K/Ar evidence on timing of metamorphism and plutonism in the Coast Mountains near Ketchikan, Alaska, in Intrusive rocks and related mineralization of the Canadian Cordillera: Geol. Assoc. Canada, Cordilleran Sec., Vancouver, B.C., Feb. 1975, Program and Abs., p. 21.

Still, P. J., 1975, Index of surface water quality records to September 30, 1973, southeast Alaska: U.S. Geol. Survey Basic Data report, 19 p., 1 sheet, scale 1:2,000,000.

Szabo, B. J., and Gard, L. M., 1975, Age of the South Bight II marine transgression at Amchitka Island, Aleutians: Geology, v. 3, no. 8, p. 457-459.

Turner, D. L., Forbes, R. B., and Naeser, Charles, 1975, Geochronology and genesis of the Kodiak-Bowie seamount chain in the Gulf of Alaska [abs.]: Am. Geophys. Union Trans., EOS, v. 56 , no. 12 , p. 1186.

Ugolini, F. C., 1975, Ice-rafted sediments as a cause of some thermokarst lakes in the Noatak River delta, Alaska: Science, v. 188 , no. 4183 , p. 51-53.

U.S. Geological Survey, 1975, Water resources data for Alaska, 1974; Pt. 1, Surface water records; Pt. 2, Water quality records: U.S. Geol. Survey annual compilation report, 322 p.

1975, Geological Survey research 1974: U.S. Geol. Survey Prof. Paper 900, 349 p.

1975, Earth science in the public service: U.S. Geol. Survey Prof. Paper 921, 73 p.

1975, Mineral resource perspectives 1975: U.S. Geol. Survey Prof. Paper 940, 24 p.

-1975, Journal of Research, v. 2, nos. 1, 2, 3, 4, 5, and 6 .

1975, Earthquake Information Bulletin, v. 7, nos. 1, 2, 3, and 4.

1975, Status of land in the Nabesna quadrangle, Alaska: U.S. Geol. Survey Misc. Field Studies Map MF-655-L, 1 sheet, scale 1:250,000.

U.S. Geological Survey, Topographic Division, 1975, Cold Bay, Alaska, Sheet No. NN-3/4: Internat. Maps of the World Ser., scale 1:1,000,000.

1975, Arctic C-5 quadrangle, Alaska: U.S. Geol. Survey,

Topog. Ser., scale 1:63,360.

-1975, Juneau D-6 quadrangle (revised), scale 1:63,360.

-1975 , Mt. Fairweather D-1 quadrangle (revised), scale

$1: 63,360$.

1975, Mr. Fairweather D-2 quadrangle (revised), scale 1:63,360.

1975, Philip Smith Mountains A-1 quadrangle, scale $1: 63,360$.

1975, Philip Smith Mountains A-2 quadrangle, scale 1:63,360.

1975, Philip Smith Mountains A-3 quadrangle, scale $1: 63,360$.

1975, Philip Smith Mountains B-1 quadrangle, scale $1: 63,360$.

1975, Philip Smith Mountains B-2 quadrangle, scale $1: 63,360$.

1975, Skagway A-3 quadrangle (revised), scale 1:63,360. 1975, Skagway A-4 quadrangle (revised) scale 1:63,360. -1975, Wiseman B-3 quadrangle, scale 1:63,360.

1975, Wiseman D-2 quadrangle, scale 1:63,360.

-1975 , Fairbanks quadrangle, scale 1:250,000.

1975, Mount McKinley National Park, Alaska, 1972, scale $1: 250,000$.

1975, The United States [A planimetric map showing Alaska and Hawaii in their proper size and position relative to the other 48 States], scale 1:6,000,000.

1975, The United States [A planimetric map showing Alaska and Hawaii in their proper size and position relative to the other 48 States], scale $1: 10,000,000$. 1975, Alaska Map E, scale 1:2,500,000.

-1975, Andreanof Islands, scale 1:1,000,000.

Von Huene, Roland, Molnia, B. F., Bruns, T. R., and Carlson, P. R., 1975, Seismic profiles of the offshore Gulf of Alaska Tertiary Province, R/V Thompson, Sept.-Oct. 1974: U.S. Geol. Survey open-file report 75-664, 15 p., 2 sheets, scale 1:250,000, 6 rolls microfilm.

Von Huene, Roland, Smith, Rodney, Hampton, Monty, Moore, George, and Dolton, Gordon, 1975, A preliminary summary of petroleum potential, environmental geology, and the technology, time-frame and infrastructure for exploration and development of the western Gulf of Alaska: U.S. Geol. Survey open-file report $75-536,52$ p., 16 figs., 2 tables.

Wahrhaftig, Clyde, Turner, D. L., Weber, F. R., and Smith, T. E., 1975, Nature and timing of movement on Hines Creek strand of Denali fault system, Alaska: Geology, v. 3, no. 8, p. 463-466.

Walker, F, K., 1975, Bibliography and index of U.S. Geological Survey publications relating to coal, January 1971-June 1974: U.S. Geol. Survey Circ. 709, 14 p.

Wanek, A. A., 1975, Geologic reconnaissance of a proposed powersite on the Maksoutof River near Sitka, southeastern Alaska: U.S. Geol. Survey Bull. 1121-F, 22 p., 1 pl.

Weber, F. R., Foster, H. L., Keith, T. E. C., and Cantelow, A. L., 1975, Reconnaissance geologic map of the Big Delta A-1 and B-1 quadrangles, Alaska: U.S. Geol. Survey Misc. Field Studies Map MF-676, 1 sheet, scale 1:63,360.

Weld, B. A., Iseri, K. T., and Horton, G. W., 1975, Reports and 
maps of the Geological Survey released only in the open files, January through April, 1974: U.S. Geol. Survey Circ. $706,10 \mathrm{p}$.

White, D. F., and Williams, D. L., eds., 1975, Assessment of geothermal resources of the United States-1975: U.S. Geol. Survey Circ. 726, 155 p.

Winkler, Gary, 1975, Deep-sea fan deposition of the Lower Tertiary Orca Group, eastern Prince William Sound, Alaska, in Recent and ancient sedimentary environments in Alaska: Alaska Geol. Soc. Symposium, Anchorage, 1975, Program and Abs., p. 37.

Wood, G. V., and Armstrong, A. K., 1975, Diagenesis and stratigraphy of the Lisburne Group Limestones of the Sad- lerochit Mountains and adjacent areas, northeastern Alaska: U.S. Geol. Survey Prof. Paper 857, 47 p., 12 pls. Yehle, L. A., 1975, Preliminary report on the reconnaissance engineering geology of the Yakutat area, Alaska, with emphasis on evaluation of earthquake and other geologic hazards: U.S. Geol. Survey open-file report 75-529, 136 p., 2 sheets, scale $1: 63,360$.

Yount, M. E., ed., 1975, United States Geological Survey Alaska program, 1975: U.S. Geol. Survey Circ. 722, 58 p.

Zenone, Chester, Donaldson, D. E., and Grunwaldt, J. J., 1975, Ground-water quality beneath solid-waste disposal sites at Anchorage, Alaska: Ground Water, v. 13, no. 2, p, 182-190. 